\title{
PHASE COMPOSITION OF PORE WATER IN COLD ROCKS
}

\author{
Malcolm Mellor
}

December 1970 
PREF ACE

This report describes studies of the phase composition of pore water in cold rocks. It forms part of a broader investigation covered by DA Task 1T062112A13001, Cold Regions Research-Applied Research and Engineering, Work Unit Mechanics of Frozen Rocks. The work was directed by Dr. Malcolm Mellor, Research Civil Engineer of the Applied Research Branch (Mr. A.F. Wuori, Chief), Experimental Engineering Division (Mr. K.A. Linell, Chief). The report has been reviewed by Dr. Pieter Hoekstra, Physical Sciences Branch, Research Division, USA CRREL.

The writer gratefully acknowledges the help and guidance of Dr. Duwayne Anderson and Dr. Pieter Hoekstra, and the active assistance and experimental contributions of Mr. Alan Greatorex and Specialists Russell Rainey, Ronald Severson, and Richard Testa.

The contents of this report are not to be used for advertising, publication, or promotional purposes. : Citation of trade names does not constitute an official endorsement or approval of the use of such commercial products. 


\section{CONTENTS}

Page

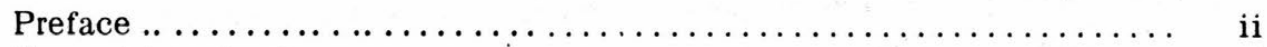

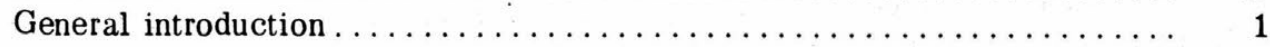

A. Pore water freezing data from differential thermal analysis ........ 2

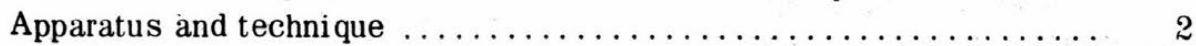

Results ...................................... 3

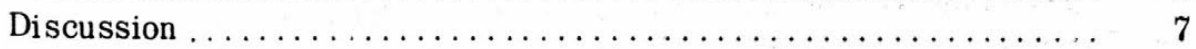

Conclusions ................................... 14

B. Indirect determination of pore water freezing data for rocks $\ldots \ldots \ldots \ldots \quad 14$

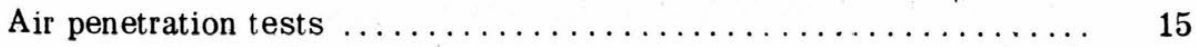

Mercury penetration measurements $\ldots \ldots \ldots \ldots \ldots \ldots \ldots \ldots \ldots \ldots$

$\begin{array}{ll}\text { Calculation of unfrozen water content and freezing point depression } & 17\end{array}$

Comparison of calculated and measured freezing characteristics .... 19

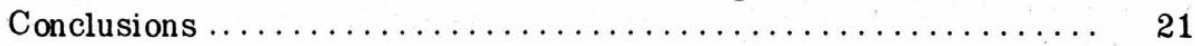

C. Electrical conductivity measurements $\ldots \ldots \ldots \ldots \ldots \ldots \ldots \ldots \ldots \ldots 21$

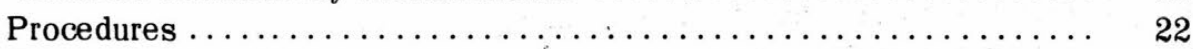

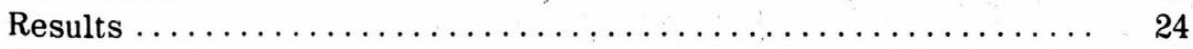

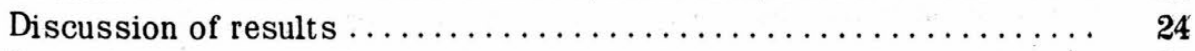

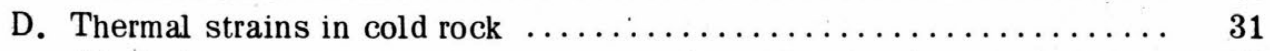

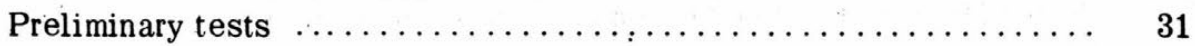

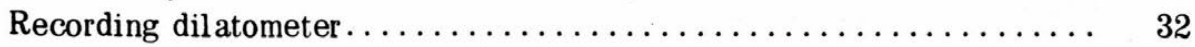

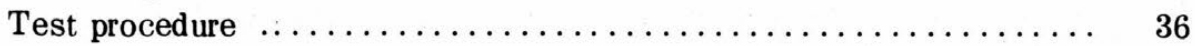

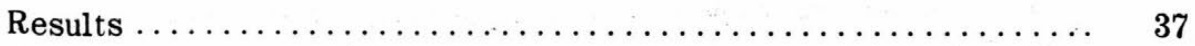

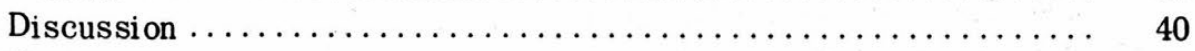

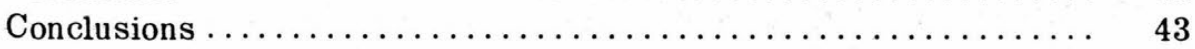

E. Isothermal compressibility of cold rocks $\ldots \ldots \ldots \ldots \ldots \ldots \ldots \ldots \ldots$

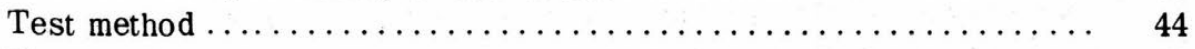

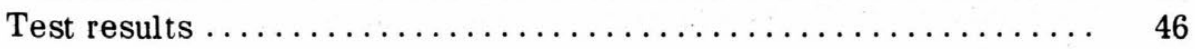

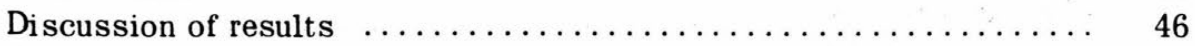

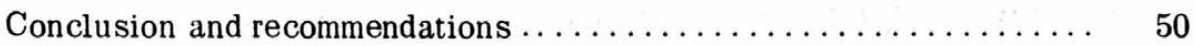

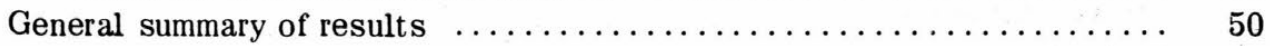

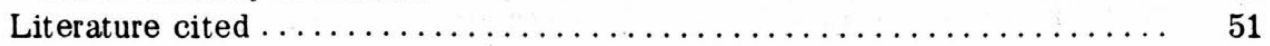

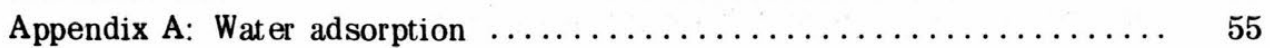

Appendix B: Adsorption and absorption by Rochester shale $\ldots \ldots \ldots \ldots \ldots \quad 57$

Appendix C: Low temperature conductivity of saturated wood ........ 59

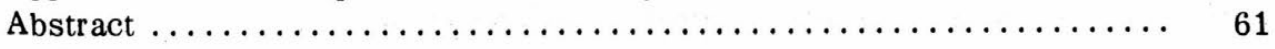

\section{TABLES}

Figure

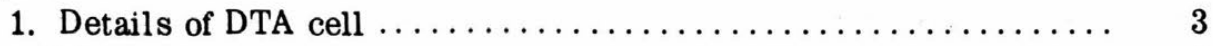

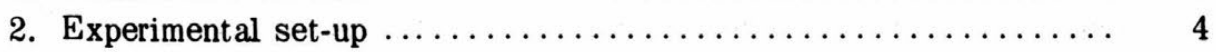

3. Freezing point depression as a function of water content for Berea

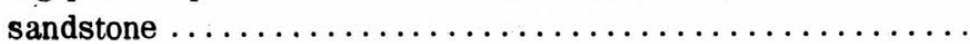

4. Freezing point depression as a function of water content for Indiana limestone 


\section{CONTENTS (Cont'd)}

\section{ILLUSTRATIONS (Cont'd)}

Figure

5. Logarithmic plot of freezing point depression against water content

Page for Berea sandstone

6. Logarithmic plot of freezing point depression against water content for Indiana limestone

7. Supercooling as a function of water content for Berea sandstone .......

8. Supercooling as a function of water content for Indiana limestone......

9. Latent heat as a function of water content for freezing of Berea sandstone

10. Latent heat as a function of water content for freezing of Indiana limestone

11. Logarithmic plot of latent heat against water content for freezing of Berea sandstone

12. Logarithmic plot of latent heat against water content for freezing of Indiana limestone

13. Air penetration data for Berea sandstone and Indiana limeston

14. Air penetration data for Barre granite $\ldots \ldots \ldots \ldots \ldots \ldots \ldots \ldots \ldots \ldots$

15. Mercury penetration data for Berea sandstone

16. Mercury penetration data for Barre granite

17. Freezing point depression as a function of water content for Berea

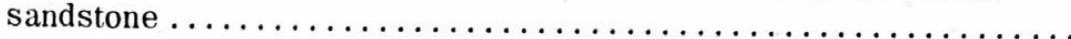

18. Freezing point depression as a function of water content for Indiana

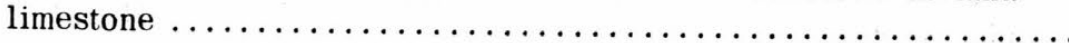

19. Freezing point depression as a function of water cont ent for Barre granite

20. ' Test cell used for low temperature electrical conductivity measurements

21. Arrangement of test cell in Dewar flask

22. Conductivity at $10^{4} \mathrm{~Hz}$ as a function of temperature for Barre granite...

23. Conductivity at $10^{4} \mathrm{~Hz}$ as a function of temperature for Indiana limestone

24. Conductivity at $10^{4} \mathrm{~Hz}$ as a function of temperature for Berea sandstone

25. Conductivity at $10^{4} \mathrm{~Hz}$ as a function of temperature for fine-grained

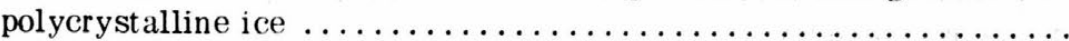

26. Conductivity at $10^{4} \mathrm{~Hz}$ as a function of temperature for fine-grained

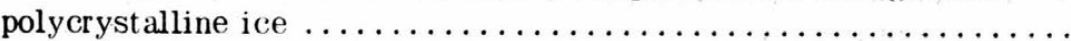

27. Conductivity plotted against $1 / \mathrm{T}$ for Barre granite $\ldots \ldots \ldots \ldots \ldots \ldots$

28. Conductivity plotted against $1 / \mathrm{T}$ for Indiana limestone $\ldots \ldots \ldots \ldots \ldots$

29. Conductivity plotted against $1 / \mathrm{T}$ for Berea sandstone $\ldots \ldots \ldots \ldots \ldots$

30. Conductivity plotted against $1 / \mathrm{T}$ for fine-grained polycrystalline ice ...

31. Optical extensomet er results for air-dry Berea sandstone $\ldots \ldots \ldots \ldots$

32. Optical extensometer results for air-dry Indiana limestone $\ldots \ldots \ldots \ldots \ldots$

33. Optical extensometer results for air-dry Barre granite $\ldots \ldots \ldots \ldots \ldots$.

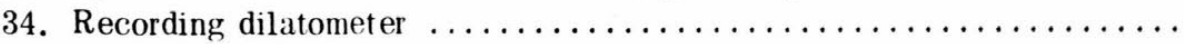

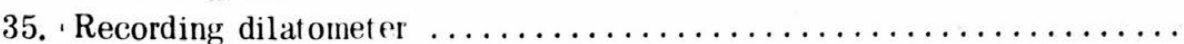

36. Calibration data from recording dilatometer $\ldots \ldots \ldots \ldots \ldots \ldots \ldots \ldots$

37. Calibration dat a from optical extensometer $\ldots \ldots \ldots \ldots \ldots \ldots \ldots \ldots \ldots$

38. Calibration data from optical extensometer $\ldots \ldots \ldots \ldots \ldots \ldots \ldots \ldots$

39. Thermal strain records for Berea sandstone $\ldots \ldots \ldots \ldots \ldots \ldots \ldots \ldots$

40. Thermal strain records for Indiana limestone $\ldots \ldots \ldots \ldots \ldots \ldots \ldots \ldots$ 
CONTENTS (Cont'd)

\section{ILLUSTRATIONS (Cont'd)}

Figure

41. Thermal strain records for Barre granite $\ldots \ldots \ldots \ldots \ldots \ldots \ldots \ldots$

42. Coefficient of linear expansion plotted against water content for Berea sandstone and Indiana limestone

43. Phase diagram for ice in the pressure-temperature plane $\ldots \ldots \ldots \ldots \ldots$

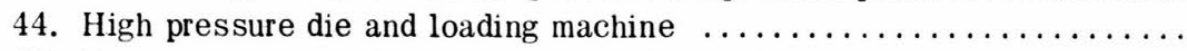

45. Pressure-volume relationships for hydrostatic compression of dry sandstone and water-saturated sandstone at $-10^{\circ} \mathrm{C}$

46. Volumetric strain as a function of hydrostatic pressure at $-10^{\circ} \mathrm{C}$ for dry sandstone and water-saturated sandstone $\ldots \ldots \ldots \ldots \ldots \ldots \ldots$

47. Pressure-volume relationships for hydrostatic compression of nominally dry and nominally saturated specimens of Indiana limestone at $-10^{\circ} \mathrm{C}$

48. Pressure-volume relationships for hydrostatic compression of nominally dry and nominally saturated specimens of Barre granite at $-10^{\circ} \mathrm{C} \ldots$.

\section{TABLES}

Table

I. DTA results for Berea sandstone $\ldots \ldots \ldots \ldots \ldots \ldots \ldots \ldots \ldots \ldots$

II. DTA results for Indiana limestone $\ldots \ldots \ldots \ldots \ldots \ldots \ldots \ldots \ldots \ldots$

III. DTA results for Berea sandstone $\ldots \ldots \ldots \ldots \ldots \ldots \ldots \ldots \ldots \ldots \ldots$

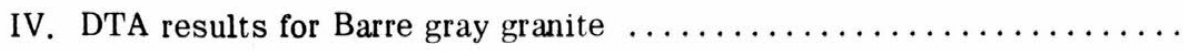

V. General properties of test specimens $\ldots \ldots \ldots \ldots \ldots \ldots \ldots \ldots \ldots \ldots$

VI. Thermal strain data for cold rocks $\ldots \ldots \ldots \ldots \ldots \ldots \ldots \ldots \ldots \ldots$

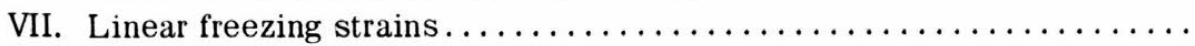

VIII. Compressibility of ice at $-10^{\circ} \mathrm{C}$ 


\title{
PHASE COMPOSITION OF PORE WATER IN COLD ROCKS
}

\author{
by \\ Malcolm Mellor
}

\section{GENERAL INTRODUCTION}

In the past, little systematic attention has been given to the effects of cold environments on rocks (as distinct from soils), and thus a study was undertaken at USA CRREL to determine how mechanical properties of rocks are affected by cold environments, and in particular by freezing of interstitial water. Since it was anticipated that mechanical properties of cold rocks would be influenced significantly by changes in state of the pore water, a subsidiary investigation into phase changes of pore water at temperatures below $0^{\circ} \mathrm{C}$ was also undertaken. : That subsidiary investigation is the subject of this report.

The main expectation, derived largely from the literature on properties of frozen soils, was that freezing of pore water would be controlled by pore geometry and interface properties, so that some water would remain liquid at temperatures well below $0^{\circ} \mathrm{C}$. Another expectation, prompted by the phase diagram for bulk ice, was that frozen pore water might undergo phase transformation at constant temperature if sufficiently high pressures were reached.

The general problem was a twofold one: 1) to determine the state of pore water as a function of temperature at constant pressure, and 2) to determine the state of pore water as a function of pressure at constant temperature. : The first requirement was for a determination of the freezing characteristics of the rocks used in the mechanical test program, i.e. it was necessary to establish the temperature for initial nucleation of ice and the relationships between liquid water content and temperature. : Other matters of interest were possible discontinuities in the temperature characteristics for pore water, and direct mechanical effects connected with thermal strain. : The investigation of pressure effects was concerned mainly with the possibility of transformations from Ice-I to water and to high pressure modifications of ice in the frozen pore water.

Since the study had to run concurrently with the main program of mechanical tests, ready availability of techniques and equipment was an important practical consideration.

Several distinct experimental techniques were employed, and the following report consists of five separate parts describing these techniques and the results obtained from them. : The subjects covered are:

A. : A determination of pore water freezing data by differential thermal analysis.

B. A study of indirect (room temperature) determination of pore water freezing characteristics.

C. Measurements of electrical conductivity as a function of temperature.

D. Measurements of thermal strain at low temperatures.

$\mathrm{E}$. Isothermal compressibility measurements at $-10^{\circ} \mathrm{C}$. 
These studies were undertaken as part of an engineering investigation, and not as fundamental research. Nevertheless, they appear to be highly relevant to geological problems of frost weathering and to problems of frost deterioration in synthetic porous materials such as concrete, brick $\mathrm{s}$ and ceramics.

\section{A. PORE WATER FREEZING DATA FROM DIFFERENTIAL THERMAL ANALYSIS}

In studying phase composition of pore water in rocks subjected to low temperatures, it was first necessary to determine the temperature at which freezing of pore water is initiated for a given water content, and to determine the amount of water which actually changes to the solid state at this temperature. : The method used was differential thermal analysis (DTA), in which the test sample and an inert reference material are heated or cooled at the same rate while the temperature difference between sample and reference is recorded. A phase change in a component of the test sample produces a perturbation in the record of temperature difference versus time. The rocks studied were Barre granite, Indiana limestone, and Berea sandstone; their water contents were varied from zero to complete saturation.

\section{Apparatus and technique}

Differential thermal analysis has been used to study the freezing of pore water in rocks by Dunn and Hudec (1965a, b), who built a precise apparatus and calibrated it to give absolute values of heat output during the freezing of pore water. For the present work a simpler arrangement was used; no attempt was made to obtain an absolute calibration for output of lat ent heat, since the method seems inherently unsuitable for precise quantitative measurements.

The system used was basically similar to one employed at the U.S. Army Cold Regions Research and Engineering Laboratory by Anderson and Tice (personal communication) for studies on frozen soils. Sample and reference are housed in a metal cylinder, which is suspended above a pool of liquid nitrogen in a Dewar flask and cooled by nitrogen vapor circulated by a const ant speed fan. Two thermocouples are embedded in the test sample, one linked to another thermocouple in the reference material to give differential temperature readings, and a second one linked to an icebath junction to give the actual temperature of the sample. Outputs from the two sensors are recorded simultaneously on a two-channel potentiometric recorder. The signal from the differential temperature sensor is passed through an amplifier before reaching the recorder.

The first DTA cell to be built was simply a scaled-up version of the cell used by Anderson and Tice for soil studies. It was a 2 -in.-diameter cylinder of low conductivity stainless steel, $2^{3 / 4}$ in. : long, bored out at one end to accommodate a rock sample $1 \mathrm{in}$. in diameter by $1 \mathrm{in.} \mathrm{long.} \mathrm{The} \mathrm{sample}$ end was covered by a $1 / 2$-in.-thick stainless steel cap, and the reference material was the solid end of the main cylinder. This cell was unsatisfactory because of poor matching of thermal conductivity between the stainless steel reference and the rock. When modified with a Lucite plug at the reference end, there remained objections on grounds of lack of symmetry.

The final design of the cell was that shown in Figure 1. The test sample and the reference plug, each $1 \mathrm{in.} \mathrm{diameter} \mathrm{by} 1 \mathrm{in.} \mathrm{long,} \mathrm{were} \mathrm{housed} \mathrm{at} \mathrm{opposite} \mathrm{ends} \mathrm{of} \mathrm{a} 2$-in.-diamet er copper cylinder, which was closed at both ends by $3 / 8$-in.-thick copper cover plates. : The copper cylinder, the rock samples, and the glass reference plug were all machined precisely to fit within 0.002 in. The thickness and the thermal conductivity of the copper cylinder were sufficient to damp out spatial and temporal fluctuations of surface temperature resulting from imperfect circulation of the cooling vapor. 

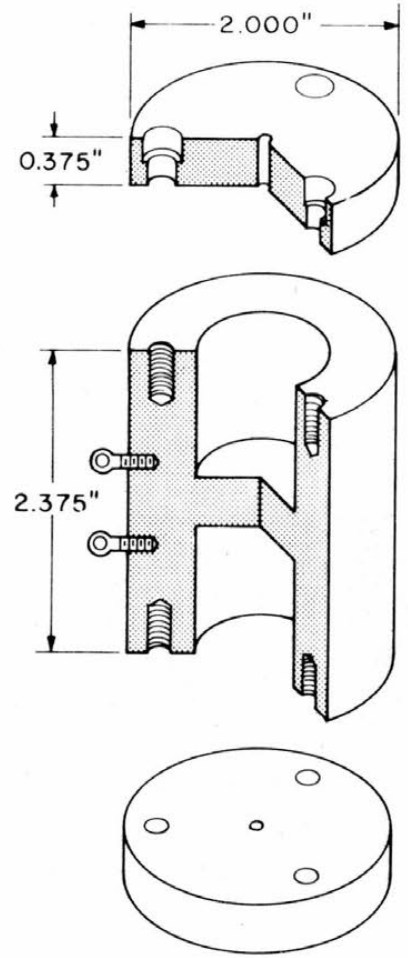

Figure 1. Details of DTA cell.

Thermocouples were placed at the center of the test sample and the reference plug. A hole $1 / 16$ in. in diameter was sufficient to admit two pairs of double-insulated 32 gauge thermocouple wires. The thermocouples were cemented in place with coldsetting epoxy adhesive, which was carefully worked in to ensure that all remaining space in the thermocouple hole was filled. The thermocouples were copper-constantan, and the actual junctions were trimmed to a length of $1 / 16$ in. The holes in the cover plates through which the thermocouple leads passed were sealed with silicone rubber adhesive.

After loading at room temperature, the DTA cell was suspended over liquid nitrogen in the Dewar flask. A stirring propeller was positioned near the cell, and the flask was closed with a 2-in.:thick split cover of foamed polyurethane. Cooling rate was adjusted roughly by proximity of the cell to the liquid nitrogen surface and by the stirring rate: the cell was typically about $1 \mathrm{in}$. above the liquid nitrogen, and stirring rate was normally maintained at $700 \mathrm{rpm}$. Cooling rates between $0^{\circ}$ and $-10^{\circ} \mathrm{C}$ were mainly in the range $1-2^{\circ} \mathrm{C} / \mathrm{min}$.

In principle the apparatus should have been capable of detecting temperature differences between sample and reference of $0.001^{\circ} \mathrm{C}$, but the electronic noise level was such that only temperature differences in excess of $0.01^{\circ} \mathrm{C}$ could be detected. This performance could be improved significantly with further work on the electronic equipment.

Each rock type tested was loaded into the cell initially while still warm after oven drying. The sample was run dry to check the apparatus and the scale settings, and to establish a base line. Distilled water was added to the surface of the high-porosity samples from a vernier syringe. The water soaked into the rock quite readily, but it apparently took many hours to diffuse throughout the sample. A cycle of cooling and warming through $10^{\circ} \mathrm{C}$ or more speeded up the diffusion of newly introduced water. To obtain complete saturation the entire cell was placed in a vacuum vessel, and the sample was removed sufficiently to permit immersion in distilled water without disconnecting the wiring.

There is a possibility that some water was adsorbed from the air before the first increment of water from the syringe was taken up.

Figure 2 shows the experimental set-up, which includes, from left to right, a stabilized d-c microvolt amplifier (Leeds and Northrup 9835) and a potentiometric recorder (Moseley 7100B), an ice bath, the main Dewar flask and stirring motor, and a constant speed control unit (Cole-Parmer model 4420).

\section{Results}

Basic results, in the form of chart records, are not reproduced here, but data abstracted from the charts are listed in Tables I-IV. Values given for supercooling are the temperatures at which nucleation occurred. Values given for freezing point depression are the temperatures to which the samples rose after initial nucleation. Values given for latent heat (in arbitrary units) are obtained from the areas of the perturbations of temperature difference, i.e. they give a measure of the integral of temperature difference with respect to time for the duration of the freezing pulse. 


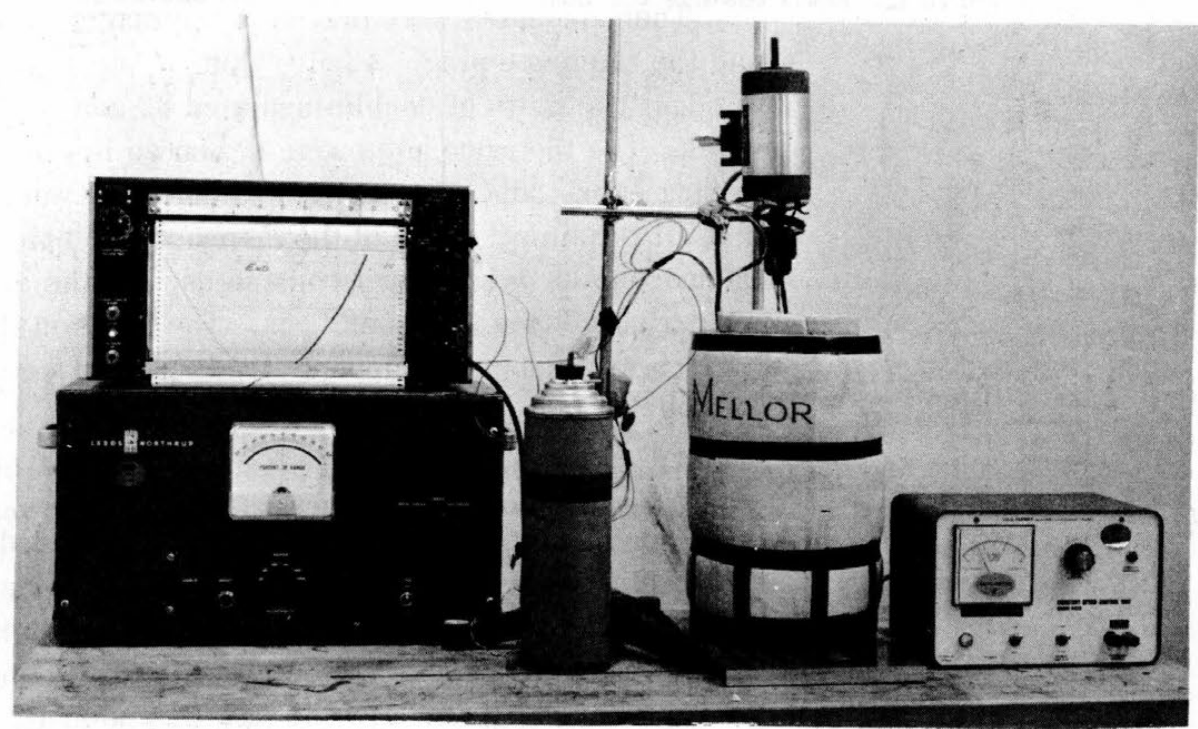

Figure 2. Experimental set-up. The items shown are, from left to right, an amplifier surmounted by a potentiometric recorder, an ice bath, a Dewar flask containing the cell and liquid nitrogen, with fan motor above and a constant speed control unit for the fan.

Table I. DTA results for Berea sandstone (first series of tests).

Sample dimensions: 1.010 in. in diameter $\times 0.998$ in. in length. Axial thermocouple hole 0.063 in. in diameter $\times 0.52$ in. in length.

Sample volume (adjusted for thermocouple hole): $0.797 \mathrm{in}^{3}=13.08 \mathrm{~cm}^{3}$

Sample mass: $27.7 \mathrm{~g}$

Dry bulk density of sample: $2.119 \mathrm{~g} / \mathrm{cm}^{3}$

Effective porosity: $19.8 \%$

Water added to sample: Distilled deionized water, conductivity $10^{-6}(\mathrm{ohm}-\mathrm{cm})^{-1}$ at $25^{\circ} \mathrm{C}$ and $60 \mathrm{~Hz}$.

\begin{tabular}{|c|c|c|c|c|c|c|}
\hline Test & $\begin{array}{c}\text { Water } \\
\text { content } \\
\quad g\end{array}$ & $\begin{array}{c}\text { Water } \\
\text { content } \\
\text { g water/ } \\
\text { g rock }\end{array}$ & $\begin{array}{l}\text { Super- } \\
\text { cobling } \\
{ }^{\circ} \mathrm{C}\end{array}$ & $\begin{array}{c}\text { Freezing } \\
\text { point } \\
\text { depression } \\
{ }^{\circ} \mathrm{C}\end{array}$ & $\begin{array}{l}\text { Latent heat } \\
\text { arbitrary } \\
\text { units }\end{array}$ & $\begin{array}{c}\text { Cooling } \\
\text { rate } \\
{ }^{\circ} \mathrm{C} / \mathrm{min}\end{array}$ \\
\hline 1 & 0 & 0 & & & & \\
\hline 2 & 0 & 0 & & & & \\
\hline 3 & 0.2 & $7.22 \times 10^{-3}$ & 2.76 & 1.14 & 0.40 & 1.17 \\
\hline 4 & 0.2 & $7.22 \times 10^{-3}$ & 3.33 & 1.61 & 0.40 & 1.56 \\
\hline 5 & 0.4 & $1.44 \times 10^{-2}$ & 2.15 & 0.43 & 0.53 & 1.14 \\
\hline 6 & 0.4 & $1.44 \times 10^{-2}$ & 2.60 & 0.41 & 0.58 & 0.89 \\
\hline 7 & 0.6 & $2.16 \times 10^{-2}$ & 2.08 & 0.35 & 0.60 & 1.40 \\
\hline 8 & 0.6 & $2.16 \times 10^{-2}$ & 2.49 & 0.30 & 0.61 & 1.12 \\
\hline 9 & 1.0 & $3.61 \times 10^{-2}$ & 2.08 & 0.25 & 0.94 & 1.04 \\
\hline 10 & 1.0 & $3.61 \times 10^{-2}$ & 2.47 & 0.30 & 0.84 & 2.00 \\
\hline 11 & 1.5 & $5.41 \times 10^{-2}$ & 1.76 & 0.25 & 1.50 & 1.15 \\
\hline 12 & 1.5 & $5.41 \times 10^{-2}$ & 2.34 & 0.27 & 1.28 & 1.49 \\
\hline 13 & 2.4 & $8.66 \times 10^{-2}$ & 0.17 & 0.08 & 2.06 & 1.36 \\
\hline 14 & 2.4 & $8.66 \times 10^{-2}$ & 1.42 & 0.16 & 2.03 & 1.68 \\
\hline 15 & 2.4 & $8.66 \times 10^{-2}$ & 0.88 & 0.12 & 2.13 & 1.43 \\
\hline
\end{tabular}


Table II. DTA results for Indiana (Bedford) limestone.

Sample dimensions: 1.010 in. in diameter $\times 0.998$ in. in length. Axial thermocouple hole 0.063 in. in diameter $\times 0.52$ in. in length.

Sample volume (adjusted for thermocouple hole): $0.797 \mathrm{in}^{3}=13.08 \mathrm{~cm}^{3}$

Sample mass: $29.95 \mathrm{~g}$

Dry bulk density of sample: $2.292 \mathrm{~g} / \mathrm{cm}^{3}$

Effective porosity: $14.1 \%$

Water added to sample: Distilled deionized water, conductivity $10^{-6}(\mathrm{ohm}-\mathrm{cm})^{-1}$ at $25^{\circ} \mathrm{C}$ and $60 \mathrm{~Hz}$.

\begin{tabular}{|c|c|c|c|c|c|c|}
\hline Test & $\begin{array}{l}\text { Water } \\
\text { content } \\
\quad g\end{array}$ & $\begin{array}{c}\text { Water } \\
\text { content } \\
\text { g water/ } \\
\text { g rock }\end{array}$ & $\begin{array}{l}\text { Super- } \\
\text { cooling } \\
{ }^{\circ} \mathrm{C}\end{array}$ & $\begin{array}{c}\text { Freezing } \\
\text { point } \\
\text { depression } \\
{ }^{\circ} \mathrm{C}\end{array}$ & $\begin{array}{c}\text { Latent heat } \\
\text { arbitrary } \\
\text { units }\end{array}$ & $\begin{array}{c}\text { Cooling } \\
\text { rate } \\
{ }^{\circ} \mathrm{C} / \mathrm{min}\end{array}$ \\
\hline 26 & 0.01 & $3.34 \times 10^{-4}$ & & & & \\
\hline 27 & 0.01 & $3.34 \times 10^{-4}$ & & & & \\
\hline 28 & 0.02 & $6.68 \times 10^{-4}$ & & & & \\
\hline 29 & 0.02 & $6.68 \times 10^{-4}$ & & & & \\
\hline $30 *$ & 0.04 & $1.34 \times 10^{-3}$ & (9.01) & (9.01) & $(0.03)$ & 1.19 \\
\hline 31 & 0.04 & $1.34 \times 10^{-3}$ & & & & \\
\hline $32 *$ & 0.06 & $2.00 \times 10^{-3}$ & $(8.77)$ & $(8.77)$ & $(0.03)$ & 1.55 \\
\hline 33 & 0.06 & $2.00 \times 10^{-3}$ & & & & \\
\hline 34 & 0.08 & $2.67 \times 10^{-3}$ & 8.42 & 8.42 & 0.052 & 1.48 \\
\hline 35 & 0.08 & $2.67 \times 10^{-3}$ & 8.53 & 8.53 & 0.039 & 1.92 \\
\hline 36 & 0.08 & $2.67 \times 10^{-3}$ & 8.66 & 8.66 & 0.048 & 1.90 \\
\hline 37 & 0.10 & $3.34 \times 10^{-3}$ & 8.26 & 8.26 & 0.076 & 2.82 \\
\hline 38 & 0.10 & $3.34 \times 10^{-3}$ & 8.16 & 8.16 & 0.092 & 2.71 \\
\hline 39 & 0.10 & $3.34 \times 10^{-3}$ & 8.74 & 8.74 & 0.090 & 2.19 \\
\hline 40 & 0.12 & $4.00 \times 10^{-3}$ & 8.40 & 8.05 & 0.12 & 1.40 \\
\hline 41 & 0.12 & $4.00 \times 10^{-3}$ & 8.79 & 8.77 & 0.12 & 2.35 \\
\hline 42 & 0.12 & $4.00 \times 10^{-3}$ & 8.66 & 8.53 & 0.11 & 1.58 \\
\hline 43 & 0.25 & $8.34 \times 10^{-3}$ & 6.41 & 4.22 & 0.45 & 1.47 \\
\hline 44 & 0.25 & $8.34 \times 10^{-3}$ & 6.65 & 4.28 & 0.49 & 2.21 \\
\hline 45 & 0.25 & $8.34 \times 10^{-3}$ & 6.67 & 3.80 & 0.46 & 1.67 \\
\hline 46 & 0.50 & $1.67 \times 10^{-2}$ & 5.36 & 1.58 & $\begin{array}{l}\text { pegged } \\
(0.76+\Delta)\end{array}$ & 1.39 \\
\hline 47 & 0.50 & $1.67 \times 10^{-2}$ & 5.88 & 2.15 & 0.92 & 2.22 \\
\hline 48 & 0.50 & $1.67 \times 10^{-2}$ & 7.02 & 2.70 & 0.86 & 1.22 \\
\hline 49 & 1.00 & $3.34 \times 10^{-2}$ & 6.54 & 0.85 & $\begin{array}{l}\text { pegged } \\
(1.61+\Delta)\end{array}$ & 1.03 \\
\hline 50 & 1.00 & $3.34 \times 10^{-2}$ & 2.60 & 1.08 & 1.75 & 1.23 \\
\hline 51 & 1.00 & $3.34 \times 10^{-2}$ & 5.75 & 0.95 & 1.66 & 1.70 \\
\hline 52 & 1.6 & $5.34 \times 10^{-2}$ & 0.93 & 0.51 & 2.69 & 1.19 \\
\hline 53 & 1.6 & $5.34 \times 10^{-2}$ & 1.27 & 0.77 & 2.73 & 1.97 \\
\hline 54 & 1.6 & $5.34 \times 10^{-2}$ & 1.03 & 0.59 & 2.84 & 1.46 \\
\hline
\end{tabular}

*Premature 
Table III. DTA results for Berea sandstone (second series of tests).

Sample dimensions: $1.010 \mathrm{in}$. in diameter $\times 0.998 \mathrm{in}$. in length. Axial thermocouple hole 0.063 in. in diameter $\times 0.52$ in. in length

Sample volume (adjusted for thermocouple hole): $0.797 \mathrm{in}^{3}=13.08 \mathrm{~cm}^{3}$

Sample mass: $27.7 \mathrm{~g}$

Dry bulk density of sample: $2.119 \mathrm{~g} / \mathrm{cm}^{3}$

Effective porosity: $19.8 \%$

Water added to sample: Distilled deionized water, conductivity $10^{-6}(\mathrm{ohm}-\mathrm{cm})^{-1}$ at $25^{\circ} \mathrm{C}$ and $60 \mathrm{~Hz}$.

\begin{tabular}{|c|c|c|c|c|c|c|}
\hline Test & $\begin{array}{c}\text { Water } \\
\text { content } \\
\quad g\end{array}$ & $\begin{array}{c}\text { Water } \\
\text { content } \\
\text { g water/ } \\
\text { g rock }\end{array}$ & $\begin{array}{l}\text { Super- } \\
\text { cooling } \\
{ }^{\circ} \mathrm{C}\end{array}$ & $\begin{array}{c}\text { Freezing } \\
\text { point } \\
\text { depression } \\
{ }^{\circ} \mathrm{C}\end{array}$ & $\begin{array}{c}\text { Latent heat } \\
\text { arbitrary } \\
\text { units }\end{array}$ & $\begin{array}{l}\text { Cooling } \\
\text { rate } \\
{ }^{\circ} \mathrm{C} / \min \end{array}$ \\
\hline 60 & 0.01 & $3.61 \times 10^{-4}$ & & & & \\
\hline 61 & 0.05 & $1.805 \times 10^{-3}$ & & & & \\
\hline 62 & 0.05 & $1.805 \times 10^{-3}$ & & & & \\
\hline $63^{*}$ & 0.10 & $3.61 \times 10^{-3}$ & & (2.52) & $(0.025)$ & \\
\hline 64 & 0.10 & $3.61 \times 10^{-3}$ & & & & \\
\hline 65 & 0.10 & $3.61 \times 10^{-3}$ & & & & \\
\hline 66 & 0.15 & $5.45 \times 10^{-3}$ & 2.60 & 2.44 & 0.044 & 1.61 \\
\hline 67 & 0.15 & $5.45 \times 10^{-3}$ & 5.09 & & 0.036 & 2.08 \\
\hline 68 & 0.15 & $5.45 \times 10^{-3}$ & 4.22 & & 0.052 & 1.55 \\
\hline 69 & 0.15 & $5.45 \times 10^{-3}$ & 4.17 & & 0.052 & 2.24 \\
\hline 70 & 0.20 & $7.22 \times 10^{.3}$ & 2.23 & 2.23 & 0.13 & 1.60 \\
\hline 71 & 0.20 & $7.22 \times 10^{-3}$ & 2.47 & 2.47 & 0.12 & 1.24 \\
\hline $72 \dagger$ & 0.10 & $3.61 \times 10^{-3}$ & & & & \\
\hline $73 \dagger$ & 0.20 & $7.22 \times 10^{-3}$ & 2.39 & 1.61 & 0.12 & 1.16 \\
\hline $74 \dagger$ & 0.20 & $7.22 \times 10^{-3}$ & 2.52 & 2.13 & 0.17 & 0.91 \\
\hline $75 \dagger$ & 0.20 & $7.22 \times 10^{-3}$ & 2.60 & 2.23 & 0.16 & 1.79 \\
\hline 76 & 0.40 & $1.44 \times 10^{-3}$ & 3.10 & 1.42 & 0.26 & 1.14 \\
\hline 77 & 0.40 & $1.44 \times 10^{-3}$ & 3.41 & 1.81 & 0.28 & 1.16 \\
\hline 78 & 0.40 & $1.44 \times 10^{-3}$ & 2.60 & 1.16 & 0.31 & 1.29 \\
\hline 79 & 0.80 & $2.88 \times 10^{-3}$ & 1.63 & 0.38 & 0.67 & 1.48 \\
\hline 80 & 0.80 & $2.88 \times 10^{-3}$ & 2.23 & 0.46 & 0.75 & 1.28 \\
\hline 81 & 0.80 & $2.88 \times 10^{-3}$ & 2.34 & 0.38 & 0.60 & 1.03 \\
\hline 82 & 1.20 & $4.33 \times 10^{-3}$ & 1.03 & 0.46 & 0.92 & 2.77 \\
\hline 83 & 1.20 & $4.33 \times 10^{-3}$ & 1.40 & 0.35 & 1.03 & 1.89 \\
\hline 84 & 1.20 & $4.33 \times 10^{-3}$ & 1.76 & 0.74 & 1.16 & 1.40 \\
\hline 85 & 1.60 & $5.77 \times 10^{-3}$ & 2.34 & 0.25 & 1.39 & 1.13 \\
\hline 86 & 1.60 & $5.77 \times 10^{-3}$ & 2.47 & 0.16 & 1.45 & 0.89 \\
\hline 87 & 1.60 & $5.77 \times 10^{-3}$ & 2.42 & 0.09 & 1.41 & 1.02 \\
\hline 88 & 2.59 & $9.35 \times 10^{-3}$ & 0.30 & 0.30 & 2.30 & 1.35 \\
\hline 89 & 2.59 & $9.35 \times 10^{-3}$ & 0.25 & 0.25 & 2.48 & 1.56 \\
\hline 90 & 2.59 & $9.35 \times 10^{-3}$ & 0.17 & 0.16 & 2.33 & 1.11 \\
\hline
\end{tabular}

* Premature.

$\dagger$ Check. 
Table IV. DTA results for Barre gray granite.

Sample dimensions: $1.010 \mathrm{in}$. in diameter $\times 0.999$ in. in length. Axial thermocouple hole 0.063 in. in diameter $\times 0.51 \mathrm{in}$. in length.

Sample volume (adjusted for thermocouple hole): $0.798 \mathrm{in}^{3}=13.09 \mathrm{~cm}^{3}$

Sample mass: $34.5 \mathrm{~g}$

Dry bulk density of sample: $2.636 \mathrm{~g} / \mathrm{cm}^{3}$

Effective porosity: $0.69 \%$,

Water added to sample: Distilled deionized water, conductivity $10^{-6}(\mathrm{ohm}-\mathrm{cm})^{-1}$ at $25^{\circ} \mathrm{C}$ and $60 \mathrm{~Hz}$.

\begin{tabular}{|c|c|c|c|c|c|c|}
\hline Test & $\begin{array}{c}\text { Water } \\
\text { content } \\
g \\
\end{array}$ & $\begin{array}{c}\text { Water } \\
\text { content } \\
\text { g water/ } \\
\text { g rock }\end{array}$ & $\begin{array}{l}\text { Super- } \\
\text { cooling } \\
{ }^{\circ} \mathrm{C}\end{array}$ & $\begin{array}{c}\text { Freezing } \\
\text { point } \\
\text { depression } \\
{ }^{\circ} \mathrm{C}\end{array}$ & $\begin{array}{c}\text { Latent heat } \\
\text { arbitrary } \\
\text { units }\end{array}$ & $\begin{array}{c}\text { Cooling } \\
\text { rate } \\
{ }^{\circ} \mathrm{C} / \mathrm{min}\end{array}$ \\
\hline 55 & 0 & 0 & & & & \\
\hline 56 & 0.090 & $2.61 \times 10^{-3}$ & 1.81 & 1.55 & 0.15 & 2.27 \\
\hline 57 & 0.090 & $2.61 \times 10^{-3}$ & 4.17 & 2.73 & 0.14 & 1.28 \\
\hline 58 & 0.090 & $2.61 \times 10^{-3}$ & 3.88 & 2.42 & 0.15 & 1.27 \\
\hline 59 & 0.090 & $2.61 \times 10^{-3}$ & 3.83 & 2.21 & 0.16 & 1.45 \\
\hline
\end{tabular}

A number of warming runs were made; data from these are not tabulated, but certain characteristics of these curves and the curves resulting from pilot tests were studied.

Data for Berea sandstone in Table I are not reliable for the lower water contents, and the data in Table III should be used in preference to these first results. The trouble in the first set of results apparently stemmed from uncontrolled adsorption during addition of the first increments of water, and possibly from segregation of water at the thermocouple, which may have been sealed imperfectly. Actually, it may be that all the lower values of water content given for Berea sandstone and Indiana limestone are too small, since there could have been adsorption from the air when the cell was loaded initially and when it was opened for the first incremental addition of water.

Figures 3 and 4 give freezing point depression as a function of water content for Berea sandstone and Indiana limestone. : In Figures 5 and 6 the same data are plotted on logarithmic scales in order to separate the points obtained for low water contents.

Figures 7 and 8 show the degree of supercooling against water content for the sandstone and the limestone.

Figures 9 and 10 give the latent heat evolved during the first phase change, in arbitrary units, as a function of water content. : In Figures 11 and 12 the same data are plotted on logarithmic scales.

\section{Discussion}

The apparatus served its limited purpose satisfactorily, but in its present form it is unsuitable for work on low porosity rocks, since water content of the rock cannot be controlled or measured with sufficient precision. Permanent attachment of the thermocouples prohibits weighing as a means of measuring water content. The alternative of sensing temperature in the jacket surrounding the sample, as adopted by Dunn and Hudec, also has certain drawbacks due to temperature lag and changes of thermal conductivity in the sample. 


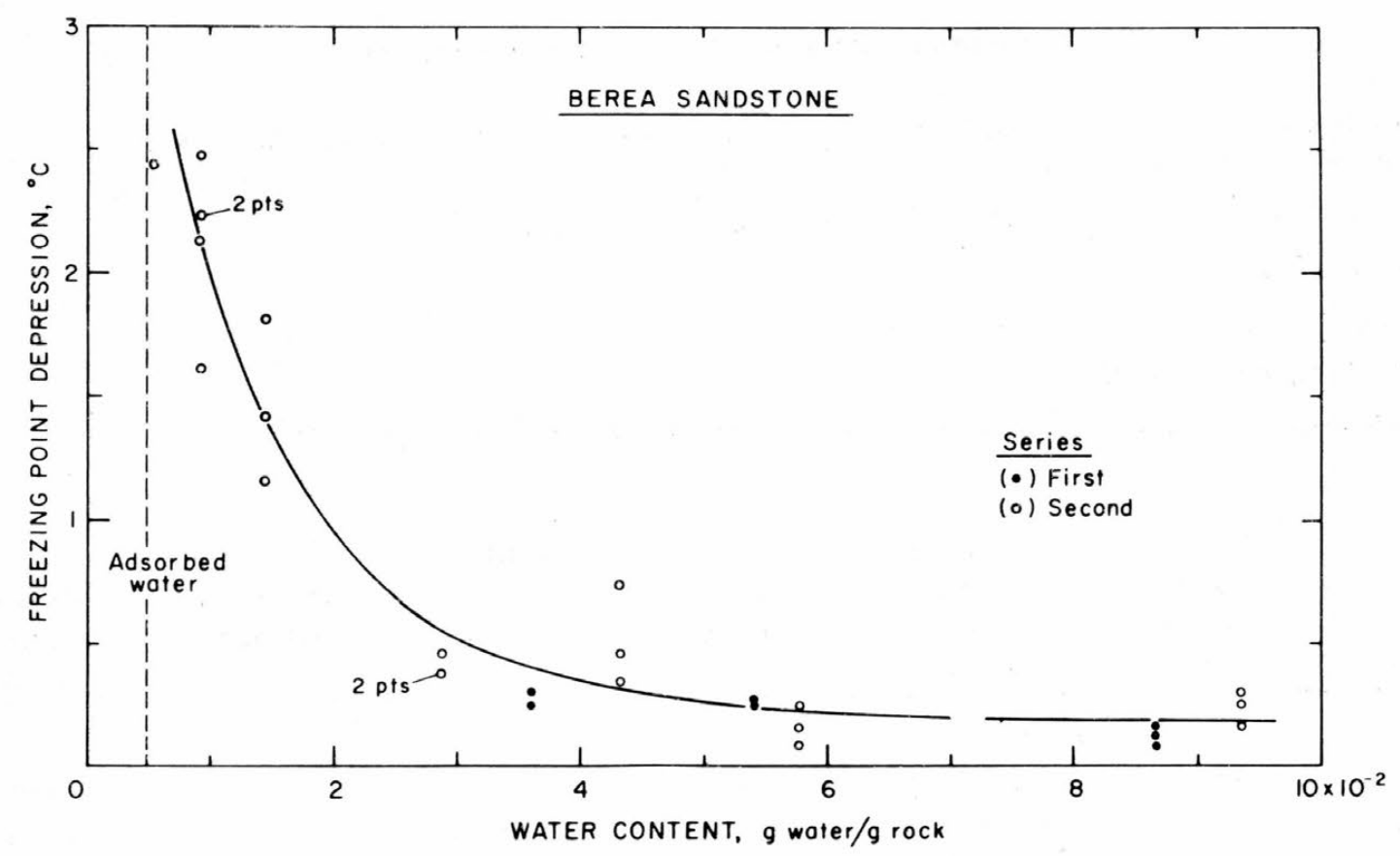

Figure 3. Freezing point depression as a function of water content for Berea sandstone.

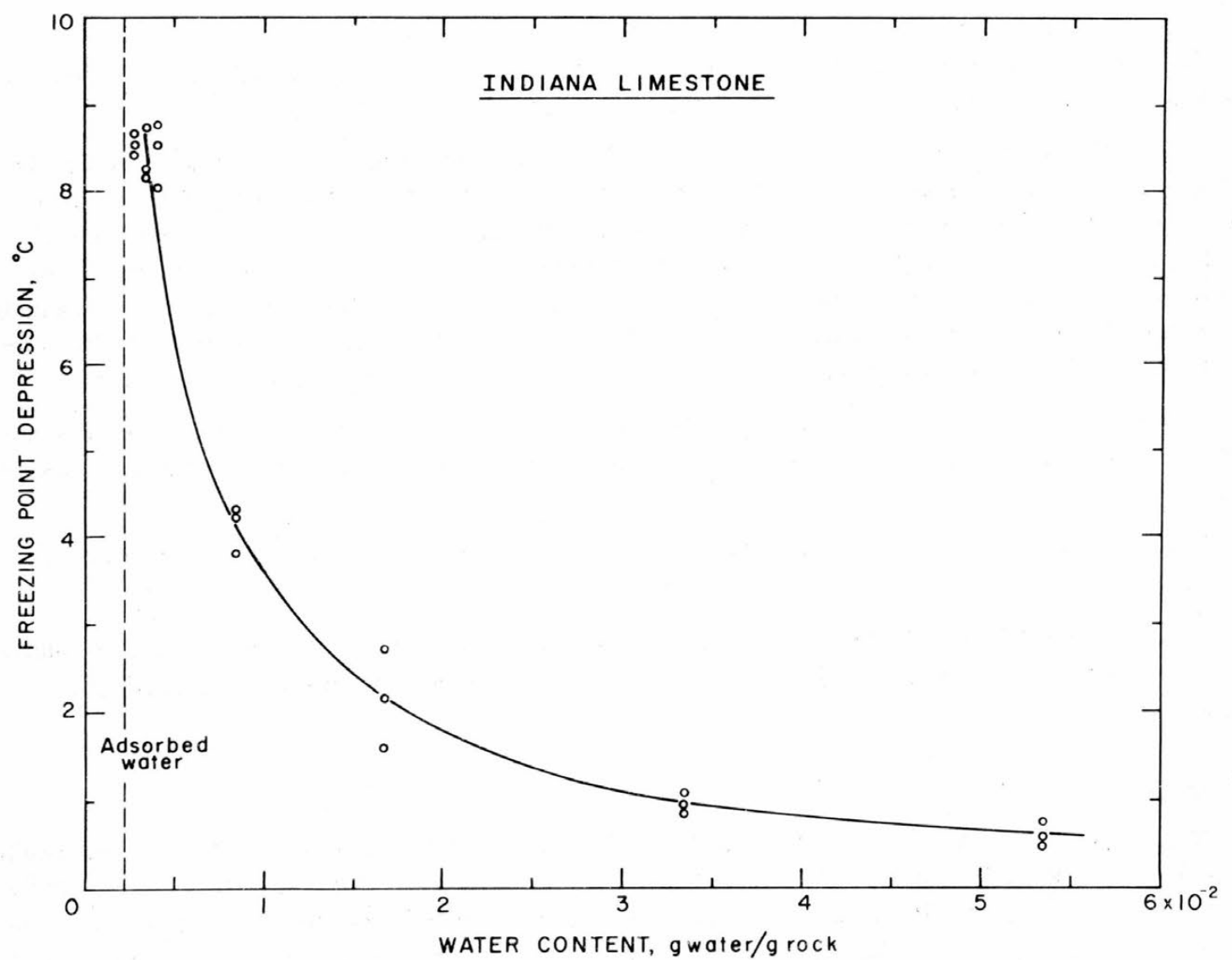

Figure 4. Freezing point depression as a function of temperature for Indiana limestone. 


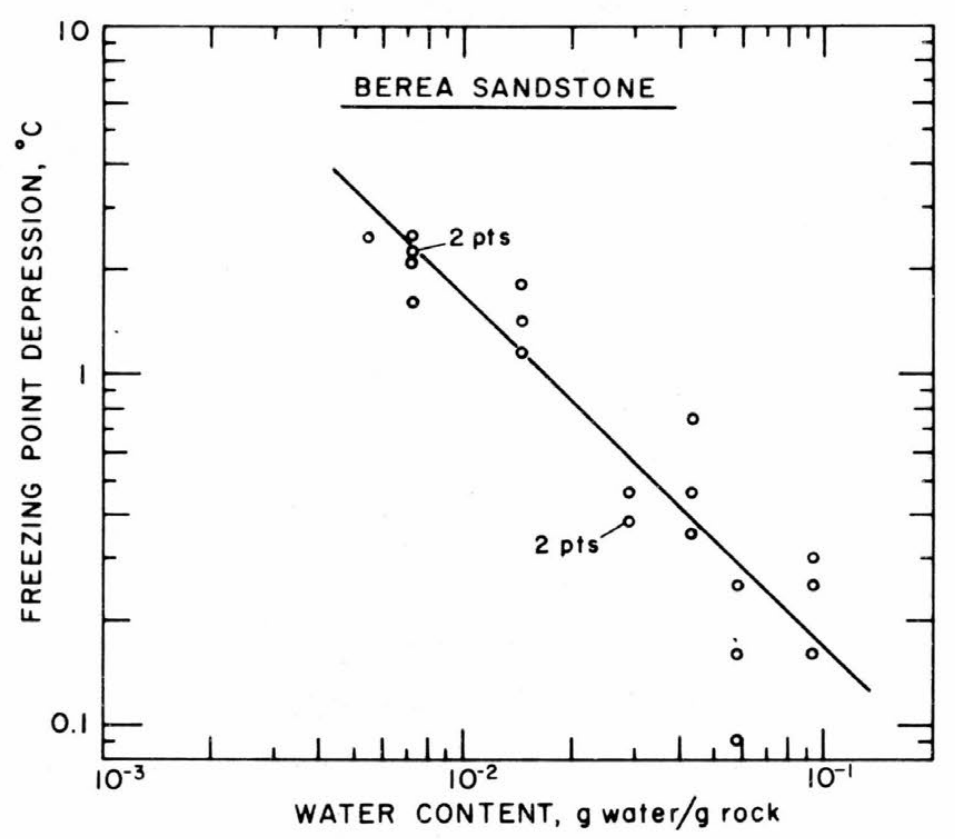

Figure 5. Logarithmic plot of freezing point depression against water content for Berea sandstone.

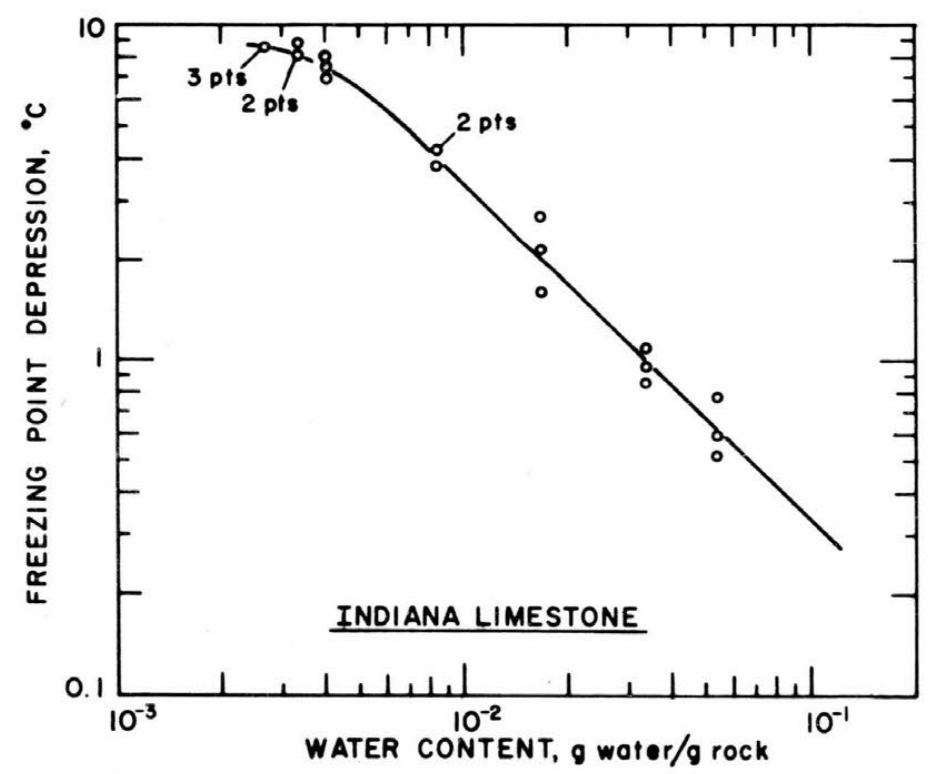

Figure 6. Logarithmic plot of freezing point depression against water content for Indiana limestone. 


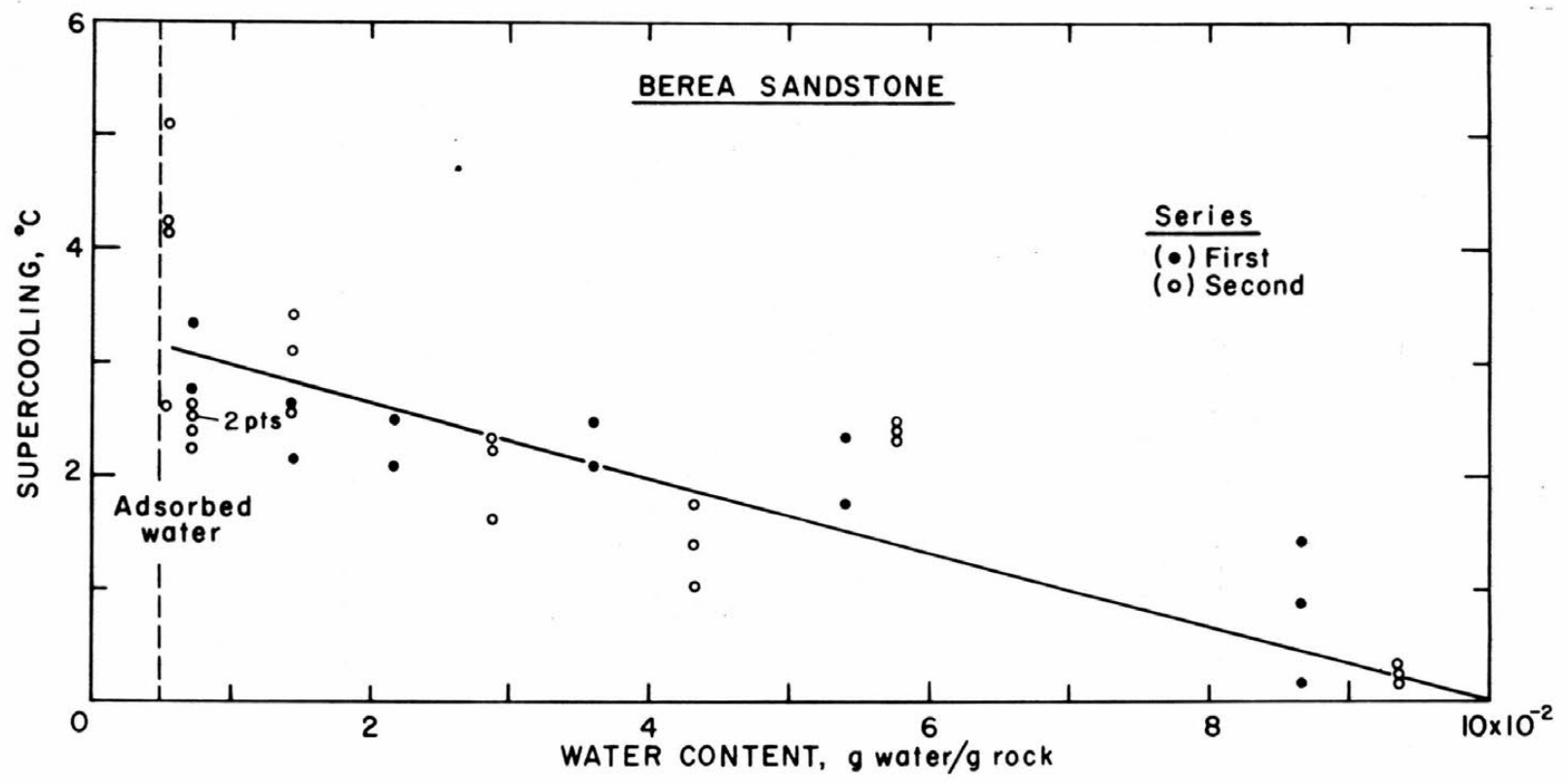

Figure 7. Supercooling as a function of water content for Berea sandstone.

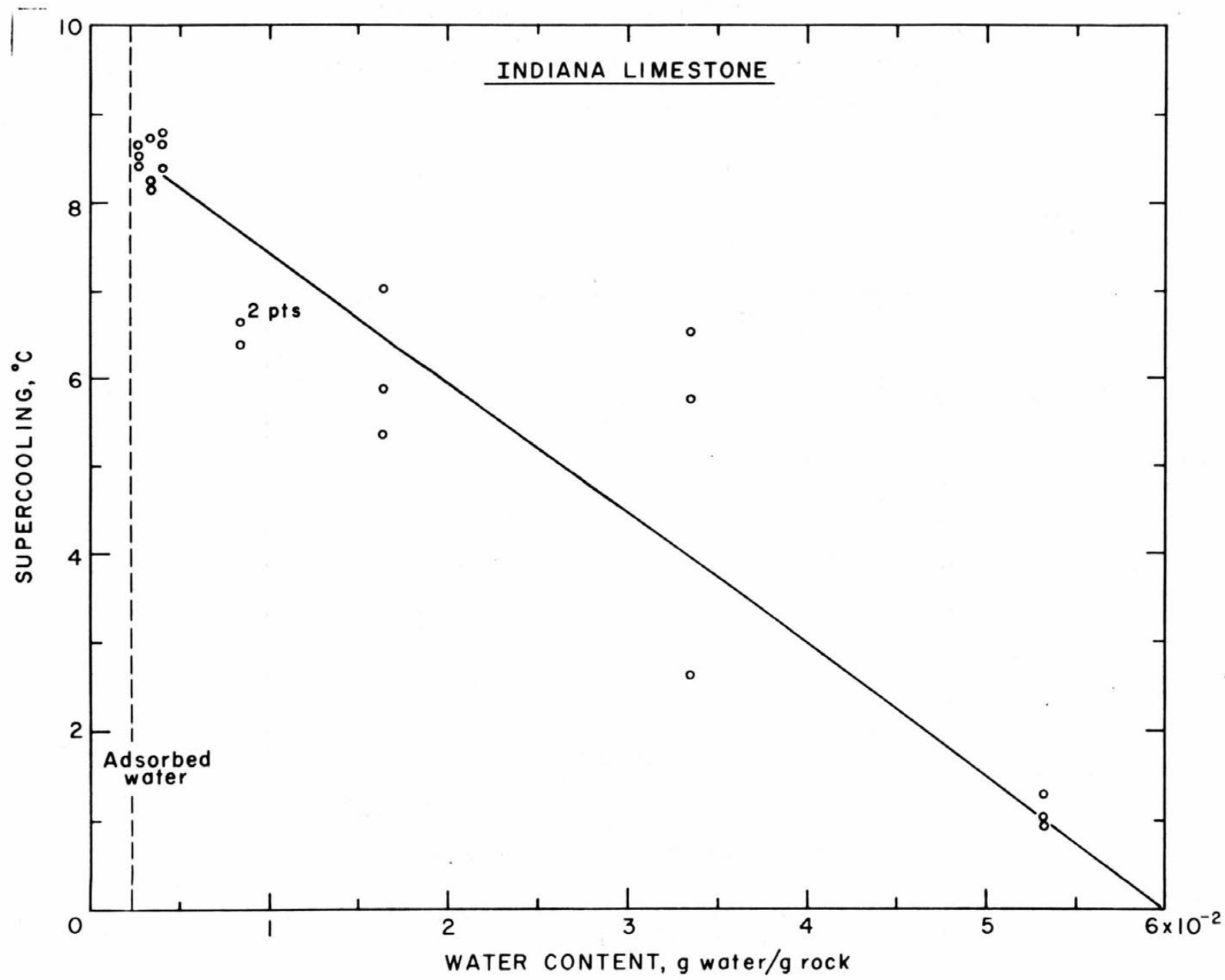

Figure 8. Supercooling as a function of water content for Indiana limestone. 


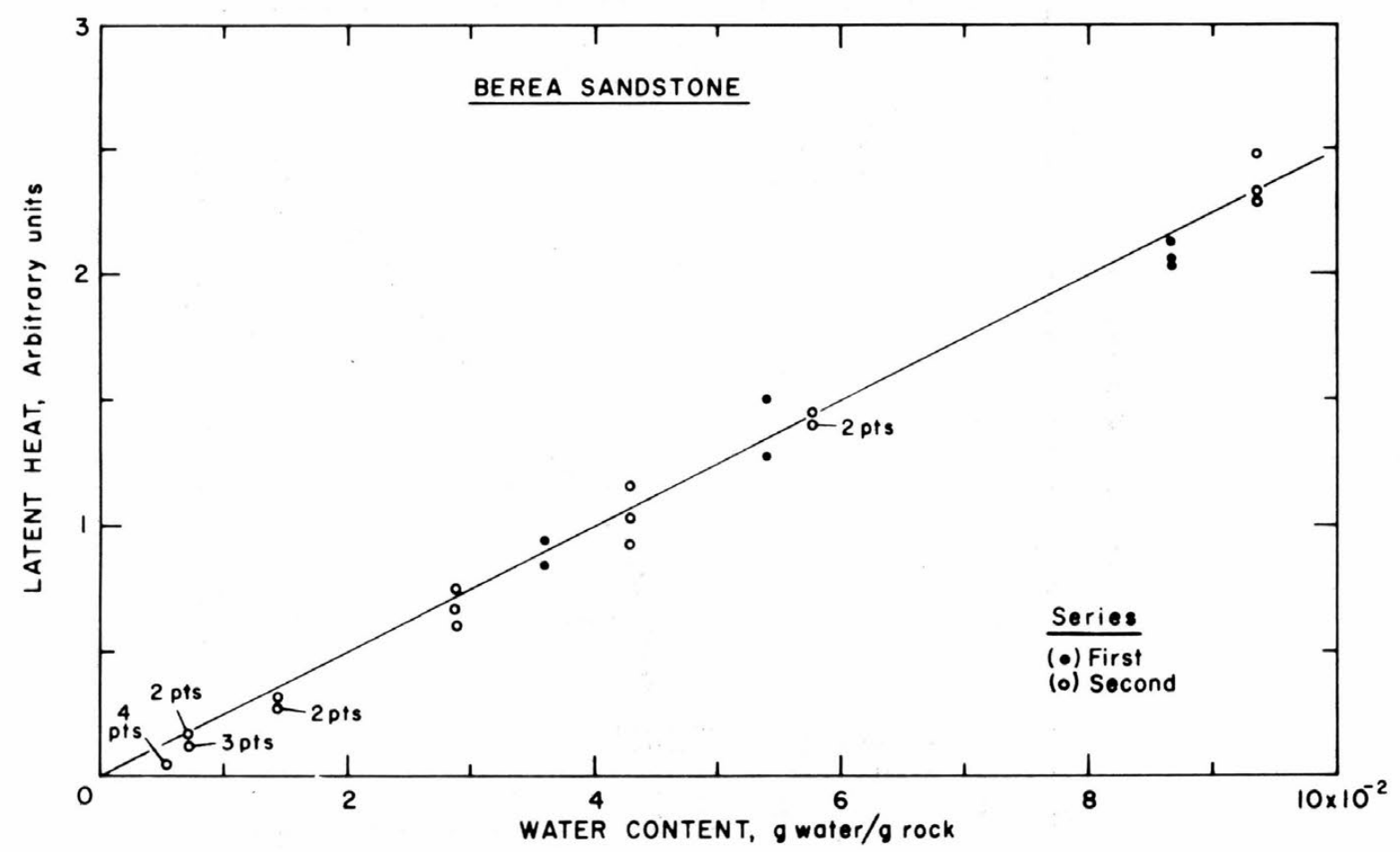

Figure 9. Latent heat as a function of water content for freezing of Berea sandstone.

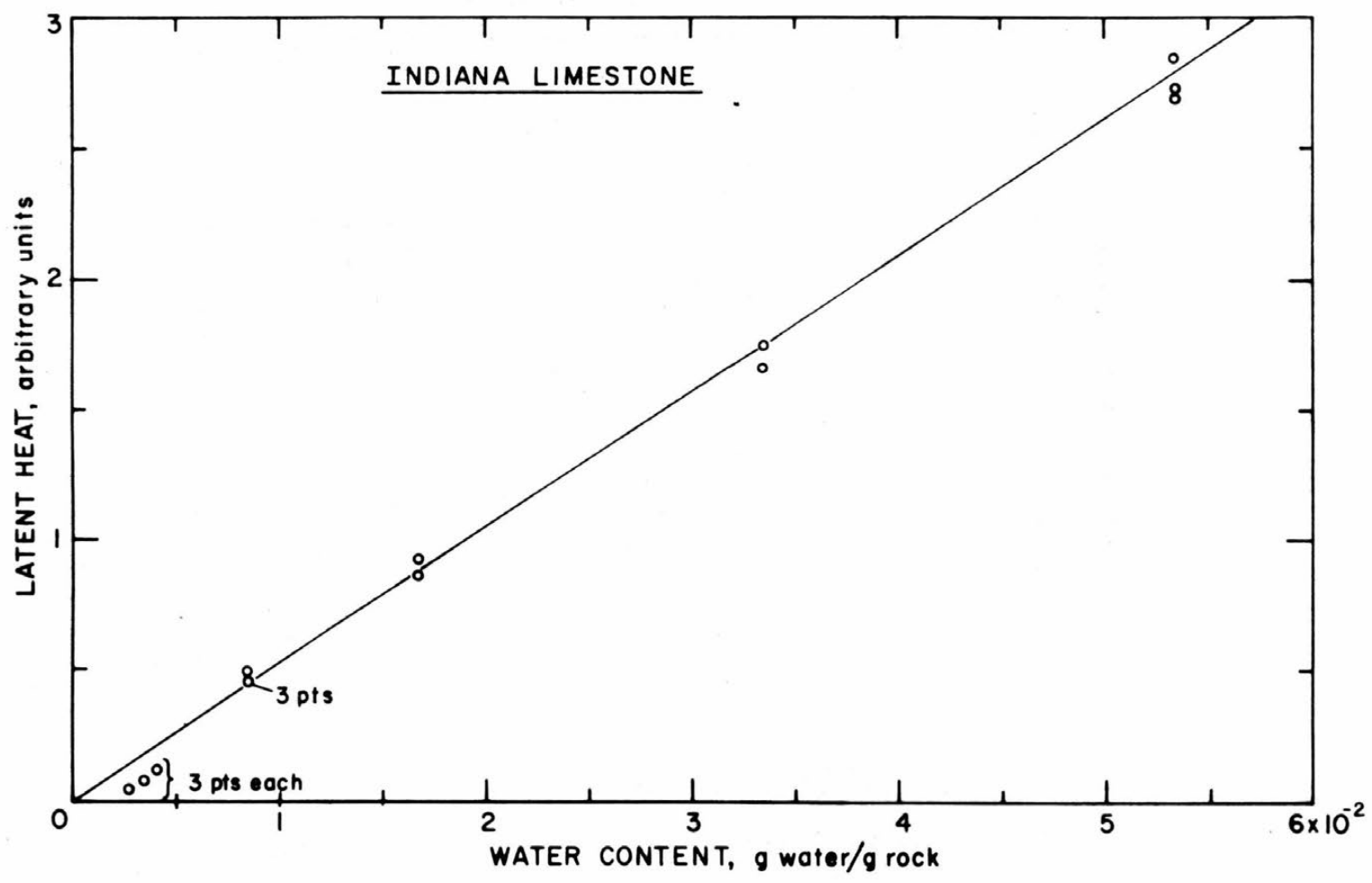

Figure 10. Latent heat as a function of water content for freezing of Indiana limestone. 


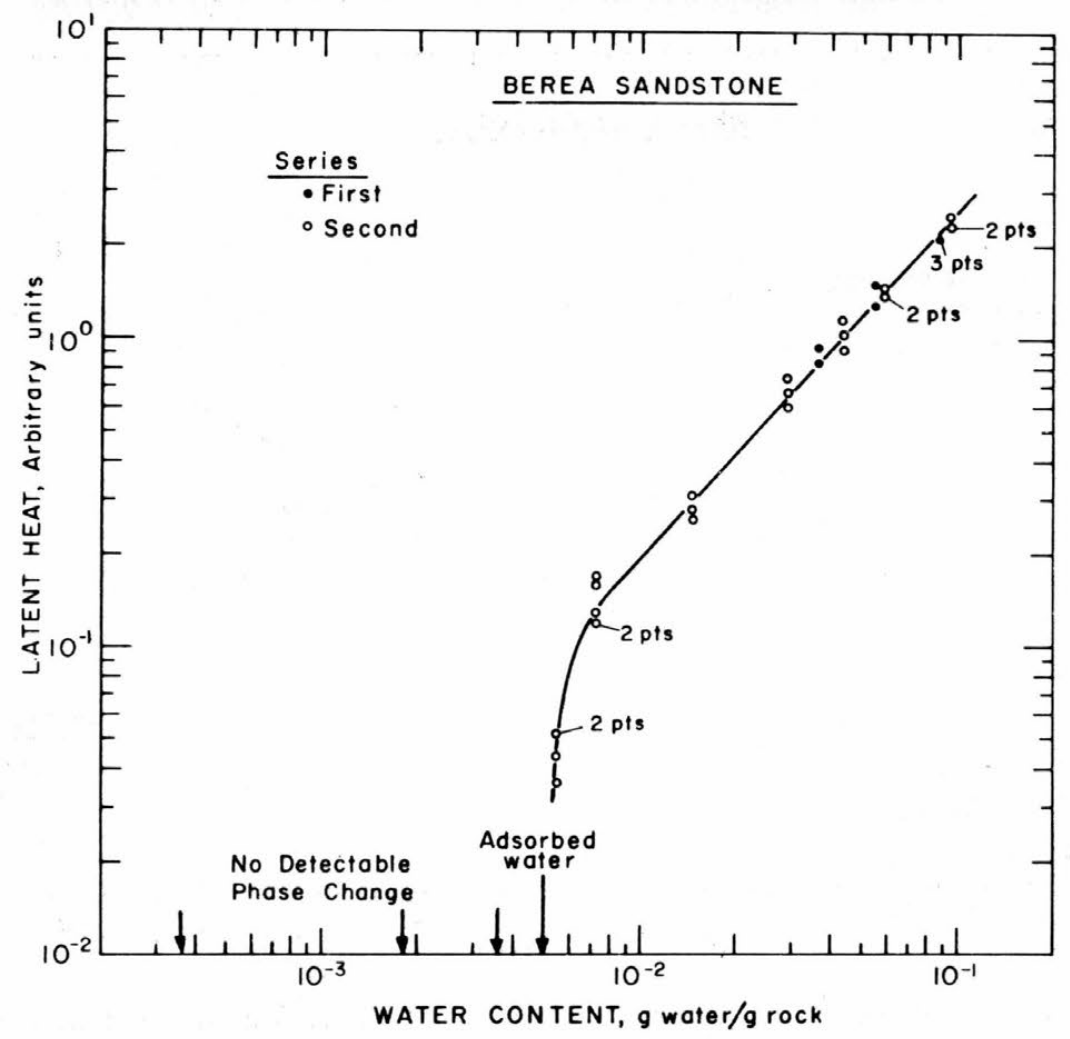

Figure 11. Logarithmic plot of latent heat against water content for freezing of Berea sandstone.

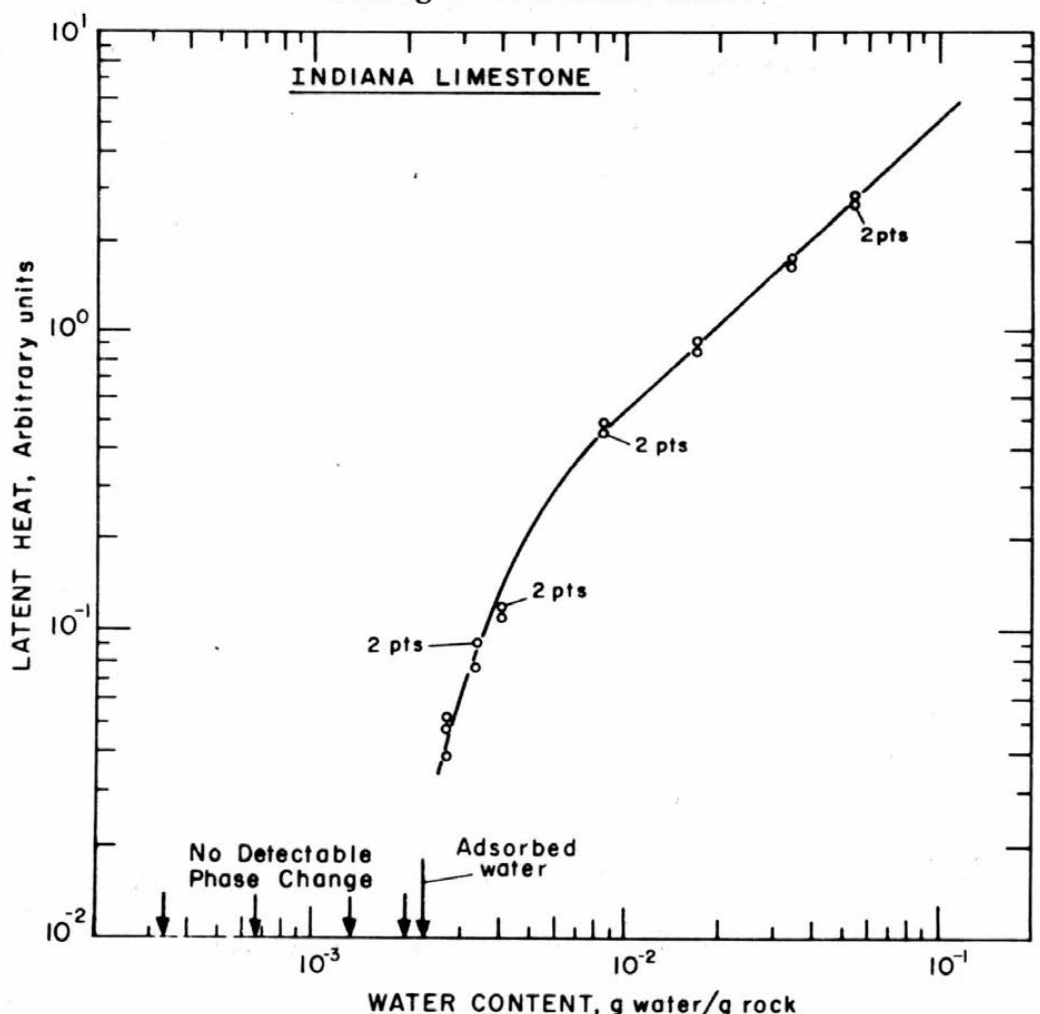

Figure 12. Logarithmic plot of latent heat against water content for freezing of Indiana limestone. 
In a discussion of work by Lange and McKim (1963), Miller (1963) criticized calorimetric determinations of freezing point depression for ceramic blocks on the grounds that latent heat liberated on free zing of small water contents would be insufficient to raise the temperature of the block from the undercooling temperature to the equilibrium freezing temperature. : Neglecting the effects of conduction, the latent heat liberated per unit volume of sample must exceed the sensible heat required to raise unit volume of the sample from the undercooling temperature to the equilibrium freezing temperature:

$$
w L \geqslant\left(S_{R}+w S_{i}\right)\left|\theta_{F}-\theta_{\mathcal{S}}\right|
$$

where $w$ is mass of water per unit mass of rock, $L$ is latent heat of fusion of ice, $S_{R}$ and $S_{i}$ are specific heats of rock and ice respectively, and $\theta_{F}$ and $\theta_{S}$ are equilibrium freezing temperature and undercooling temperature respectively. The test of an observation is that

$$
\left(\frac{S_{R}}{w L}+\frac{S_{i}}{L}\right)\left|\theta_{F}^{\prime}-\theta_{S}\right|<1
$$

where $\theta_{F}^{\prime}$ is the apparent equilibrium freezing temperature. Taking $S_{R}=0.2 \mathrm{cal} / \mathrm{g}-{ }^{\circ} \mathrm{C}$, $S_{i}=0.5 \mathrm{cal} / \mathrm{g}-{ }^{\circ} \mathrm{C}, L=80 \mathrm{cal} / \mathrm{g}$, this becomes:

$$
\left(\frac{2.5 \times 10^{-3}}{W}+6.25 \times 10^{-3}\right)\left|\theta_{F}^{\prime}-\theta_{S}\right|<1 .
$$

By this criterion, only three of the observed values for freezing point depression are deficient; they are tests 57, 58, 59 for saturated Barre granite. However, it seems clear that neither differential thermal analysis nor calorimetry are suitable techniques for determining pore water freezing characteristics in rocks of very low porosity.

The apparatus used was insufficiently sensitive to detect possible secondary phase changes in the temperature range $-35^{\circ}$ to $-40^{\circ} \mathrm{C}$, such as have been found in clays by Anderson and Tice (personal communication). The low porosity and low surface area of typical rock lead to water contents per unit mass which are smaller than those typical for fine-grained soils, and this means that equipment for work on rocks must be correspondingly more sensitive than that used for soil studies.

If new apparatus were to be built, consideration would be given to the use of "long" cylindrical samples. This would permit the results to be analyzed so as to give the thermal diffusivity of the rock relative to that of the reference as a function of temperature (see, for example, Jellinek and Fok, 1967).

Since unfrozen water content is almost independent of total water content (Anderson, 1967), the curves giving freezing point depression as a function of water content (Fig. 3 and 4) may also be interpreted as curves showing unfrozen water content of the rock as a function of temperature. These curves are used later to check the feasibility of obtaining such data from moisture characteristics measured at room temperature in a pressure membrane apparatus, as suggested by Keune and Hoekstra (1967).

The logarithmic plots of freezing point depression against water content (Fig. 5 and 6) indicate that for some practical purposes it may be permissible to assume that freezing point depression in high porosity rocks is inversely proportional to water content. 
Latent heat data for sandstone and limestone (Fig. 9-12) indicate that freezing is incomplete for water contents below about $7 \times 10^{-3} \mathrm{~g}$ water/g rock. The results accord well with the finding of Dunn and Hudec (1965b), who also found that the water adsorbed when rock is exposed to a $100 \%$ relative humidity environment is unfreezable in the normal sense. : No abrupt phase changes were detected for water contents below the adsorbed water content (measurements of adsorbed water content are given in Appendix A).

An approximate calibration for latent heat can be obtained for Figures 9 and 10 since the amount of water freezing at high water contents can be closely estimated.

\section{Conclusions}

Low temperature differential thermal analysis of rocks provides an acceptable method of determining pore water freezing characteristics, although it is not really suitable for work on rocks of very low porosity, or for work at very small water contents. : The required measurements are time-consuming, and it would be desirable to develop a simpler method for estimating pore water freezing characteristics so that this information could be obtained routinely in ordinary testing laboratories.

For each rock type at a given water content there is a characteristic depression of the freezing point for initial nucleation of pore water. In the absence of gross chemical contamination, this depression of the freezing point is probably controlled by the pore geometry. For a given rock type there is a characteristic relationship between freezing point depression and water content. : At high water contents, freezing point depression tends to a limiting small value, and it becomes indefinitely large as water content tends to a limiting small value, which appears to correspond with the maximum adsorbed water content of the rock.

If the amount of unfrozen water in a rock is substantially independent of the total water content of the rock, then curves relating freezing point depression with water content can be interpreted as relationships between unfrozen water content and temperature. : This is found to be the case for frozen soils (Anderson, 1967). By this token the low water content asymptotic limit for curves of freezing point depression can be regarded as water which is virtually unfreezable under typical environmental low temperatures. : Both the present writer and Dunn and Hudec (1965b) find that the amount of "unfreezable" water corresponds to the maximum adsorbed water content of the rock, and since this can be measured easily at room temperature (Appendix A) it seems to be a valuable practical parameter (see Appendix B for an example).

\section{B. INDIRECT DETERMINATION OF PORE WATER FREEZING DATA FOR ROCKS}

In studies described in Part A, the phase composition of pore water at low temperature was explored by differential thermal analysis (DTA). Of particular interest were freezing point depression curves yielded by DTA, since these curves may be interpreted either as freezing point depression as a function of water content or as unfrozen water content in saturated rock as a function of temperature. However, with the existing DTA apparatus these curves are not easy to obtain, particularly for rocks of low porosity.

For more than 30 years a relationship between the free energy, or surface tension, of soil moisture and freezing point depression has been recognized (Schofield and DaCosta, 1938), and recently a rigorous treatment of the relevant thermodynamics has been given by Low et al. (1968). In connection with the work by Low et al., Keune and Hoekstra (1967) suggested that, as an alternative to difficult low temperature measurements, the unfrozen water content of frozen soils 
might be calculated from standard soil moisture characteristics measured at room temperature in a pressure-membrane apparatus. : They calculated unfrozen water contents for a range of soil types from moisture characteristics, but no independent experimental verifications were given.

In view of the difficulty and expense of DTA or calorimetry for rocks, it was decided that indirect methods should be investigated.

\section{Air penetration tests}

Air penetration measurements were made on rock specimens using a standard soils laboratory pressure membrane apparatus (15-bar ceramic plate extractor, Soilmoisture Equipment Co.). Air pressure was supplied to the apparatus through a special manifold system from a compressor and storage tank. The maximum pressure of this apparatus ( 15 bar) was really too small to suit the experiment, but higher pressure equipment was not immediately available.

The rock samples were $2^{1 / 8}$-in.-diameter disks, 1/2 in. thick. For Berea sandstone and Barre granite, 9 identical samples of each rock were tested, and for Indiana limestone 12 samples were tested. The samples were first oven-dried at $110^{\circ} \mathrm{C}$ and weighed on an Ainsworth balance to $0.001 \mathrm{~g}$. They were then saturated by evacuation followed by immersion in de-aired water while still under vacuum. After surface drying they were reweighed to obtain the saturation water content. The saturated samples were placed on the ceramic plate (which has previously been saturated under pressure), the pressure chamber was closed, and a fixed pressure was applied and maintained for two days. Pressure was then released, the samples were rapidly weighed to find the water loss, and they were returned to the pressure chamber. This procedure was repeated at increasing increments of pressure.

There were some teething troubles with the apparatus, which had not previously been used, and two ceramic plates were broken during test runs. Each run suffered one interruption, and the test results show discontinuities corresponding to the interruptions. This is perhaps caused by hysteresis effects, which are known to exist for soils. However, these small imperfections in the data have no significant effect on the final results of the experiment.

The test results are shown in Figures 13 and 14, where water content and air penetration volume are plotted against the pressure differential. It might be noted that these results can be used to make an estimate of pore size, assuming that the pores are tubular capillaries. From elementary capillary theory (Adamson, 1960):

$$
\Delta P=\frac{2 \gamma \cos \phi}{r}
$$

where $\Delta P$ is the pressure differential, $\gamma$ is surface tension for water/air at room temperature ( $\approx 72$ dynes $/ \mathrm{cm}$ ), $\phi$ is the contact angle (zero for water), and $r$ is pore radius. Effective pore radius is marked on Figures 13 and 14 although a logarithmic scale is more suitable for this purpose. :

\section{Mercury penetration measurements}

The pressures reached in the air penetration tests were insufficient to provide freezing point data for temperatures below $-1.5^{\circ} \mathrm{C}$. Although high pressure air penetration apparatus was not available, high pressure mercury intrusion measurements had previously been made on the three rocks to determine pore size distributions, and there seems to be no obvious reason why these data cannot be used to give high pressure penetration data for water/air when adjustments for surface tension and contact angle are made. 


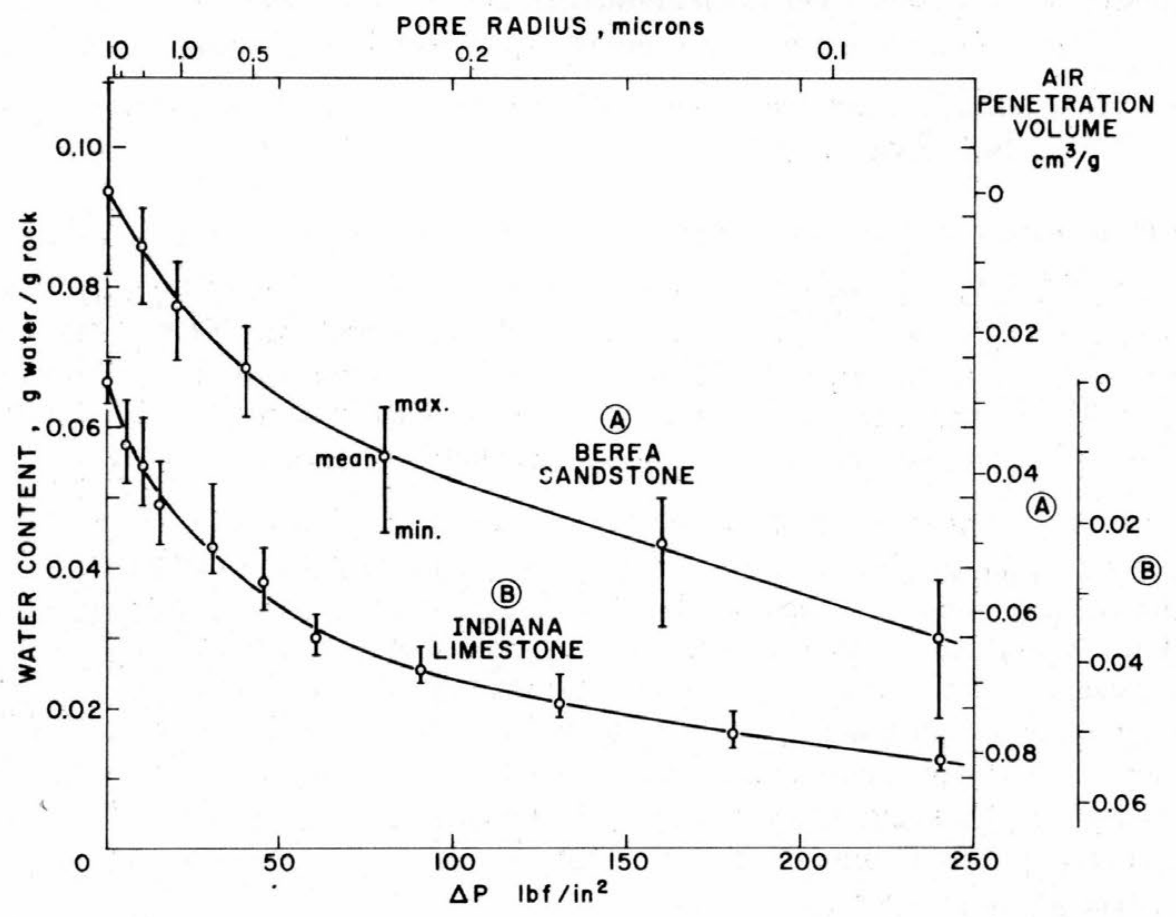

Figure 13. Air penetration data for Berea sandstone and Indiana limestone.

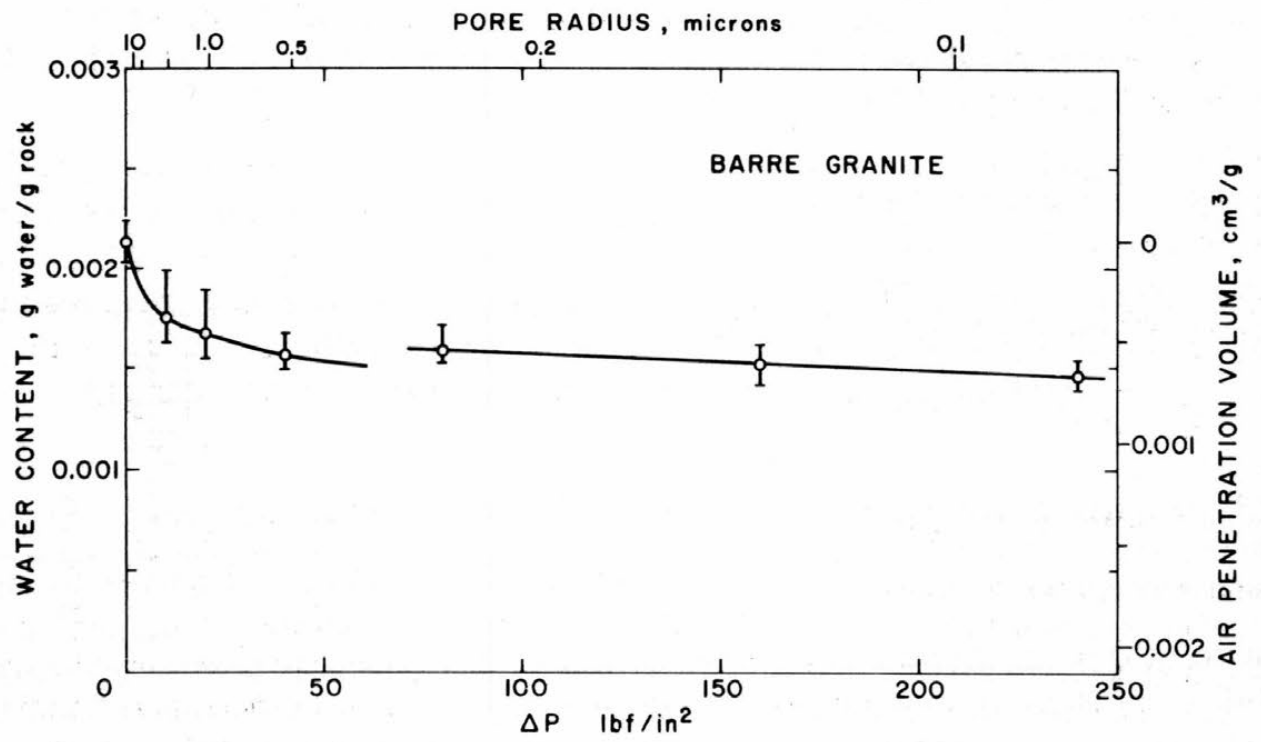

Figure 14. Air penetration data for Barre granite. 
Equation 4 gives the following relationship between mercury penetration pressure in vacuum and air penetration against water for a given pore size $r$ :

$$
\frac{\Delta P_{a}}{\Delta P_{m}}=\frac{\gamma_{w}}{\gamma_{m} \cos \phi_{m}}
$$

where $\Delta \boldsymbol{P}_{\mathrm{a}}$ and $\Delta \boldsymbol{P}_{\mathrm{m}}$ are corresponding pressure differentials for penetration of air and mercury respectively into pores of a given size, $\gamma_{w}$ is surface tension for water/air, $\gamma_{m}$ is surface tension for mercury/vacuum, and $\phi_{m}$ is contact angle for mercury. Taking the contact angle for mercury and rock surfaces as $130^{\circ}$, the surface tension of mercury in vacuum as 474 dynes $/ \mathrm{cm}$ at $25^{\circ} \mathrm{C}$, and the surface tension of water/air as 72 dynes/cm:

$$
\Delta P_{\mathrm{a}}=0.2365 \Delta P_{m} .
$$

Using this relationship, the mercury penetration data of Figures 15 and 16, which give: penetration volume as a function of pressure, can be interpreted in terms of air penetration against water. Available mercury penetration data for Indiana limestone have to be discarded, as comparison with water saturation and air pycnometer data clearly show that they are in error - indicated penetration volumes are too low by a factor of 2.2 .

\section{Calculation of unfrozen water content and freezing point depression}

The object of the calculation is to find a relationship between water content and pressure. Keune and Hoekstra derive a relationship between soil water tension (or air penetration pressure) $\Delta P$ and partial molar free energy $\Delta \bar{F}_{1}$ :

$$
\Delta \bar{F}_{1}=-\bar{V}_{1} \Delta P
$$

where $\nabla_{1}$ is the partial molar volume of soil water. But the partial molar free energy of water/ice in a frozen soil is a function of temperature:

$$
\Delta \bar{F}_{1}=R T \ln \left(p^{\square} / p^{\circ}\right)
$$

where $T$ is absolute temperature, $R$ is the gas constant, $p^{0}$ is the vapor pressure of ice, and $p^{\circ}$ is the vapor pressure of a standard state, chosen as bulk supercooled water at the temperature of the sample. Taking $\bar{V}_{1}$ as $18 \mathrm{~cm}^{3} /$ mole for water, and taking values of $p^{\square}$ and $p^{\circ}$ as a function of temperature from Dorsey (1940), the required relationship between freezing point depression $\theta$ and pressure differential $\Delta P$ is, in the units used for measurement:

$$
\theta=5.85 \times 10^{-3} \Delta P
$$

where $\theta$ is in degrees Celsius and $\Delta P$ is in lbf/in. ${ }^{2}$ Equation 9 thus converts the measured relationship between water content and $\Delta P$ to a relationship between water content and temperature (or freezing point depression).

In the case of the mercury penetration measurements and their air penetration equivalents, penetration volume is given as a function of pressure. For water-filled samples: water content/unit mass $=($ total pore vol/unit mass - penetrated vol/unit mass $) \times($ density of water $)$.

The porosity values taken in reduction of the mercury penetration data were those measured in the air comparison pycnometer, viz Berea sandstone $20.6 \%$, Barre granite $1.2 \%$. The dry bulk densities were: Berea sandstone $2.119 \mathrm{~g} / \mathrm{cm}^{3}$, Barre granite $2.636 \mathrm{~g} / \mathrm{cm}^{3}$. 


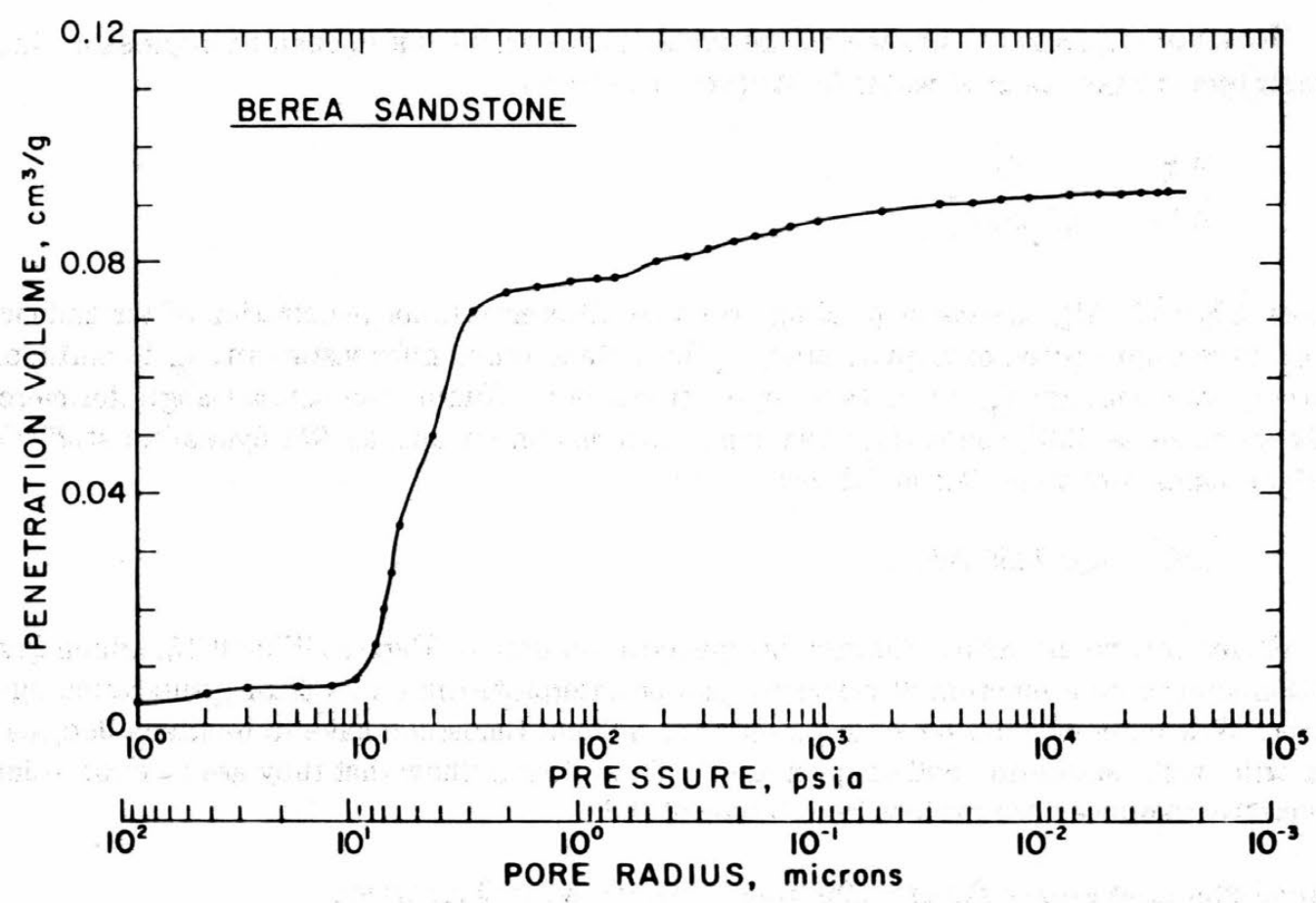

Figure 15. Mercury penetration data for Berea sandstone.

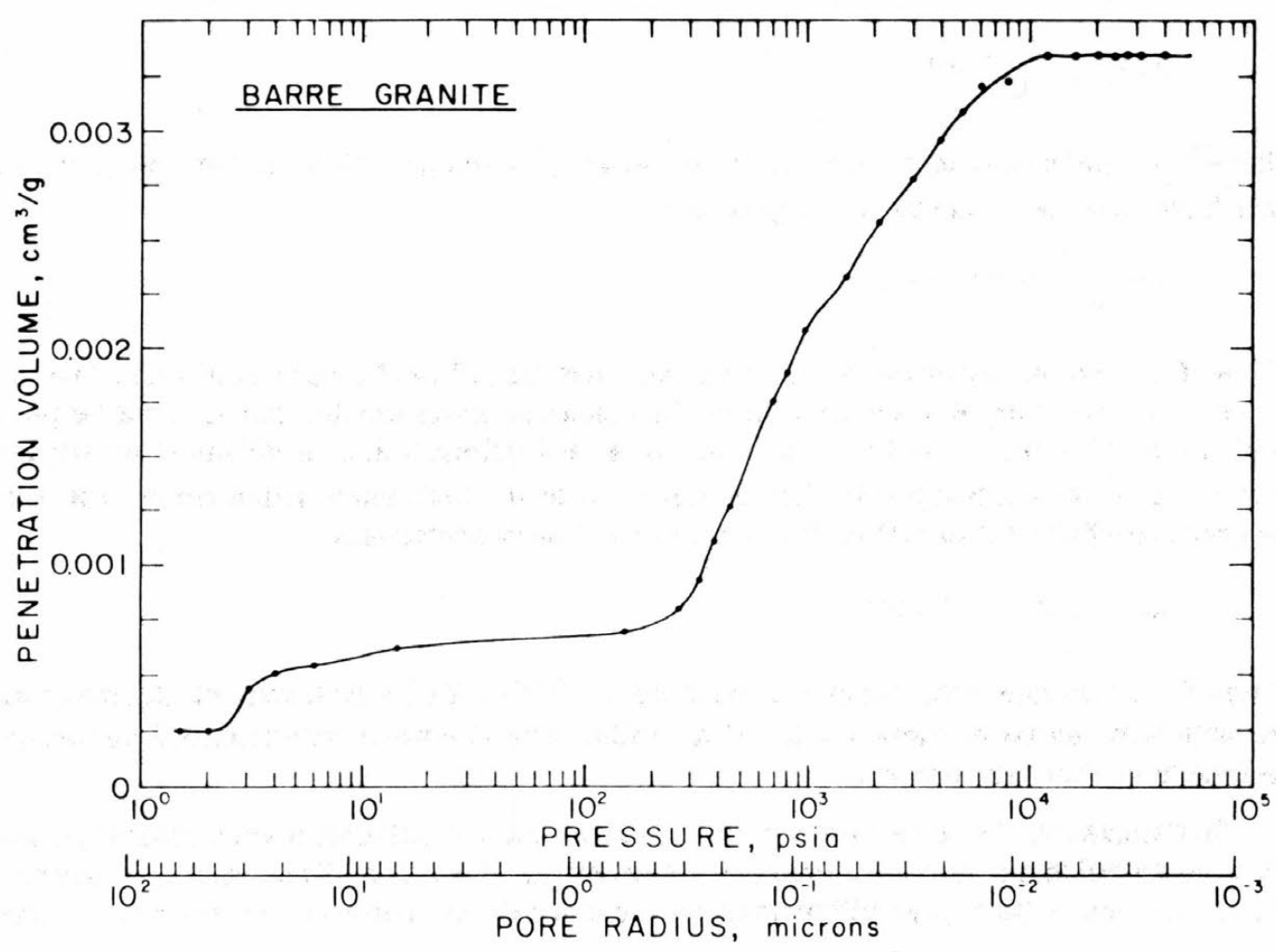

Figure 16. Mercury penetration data for Barre granite. 


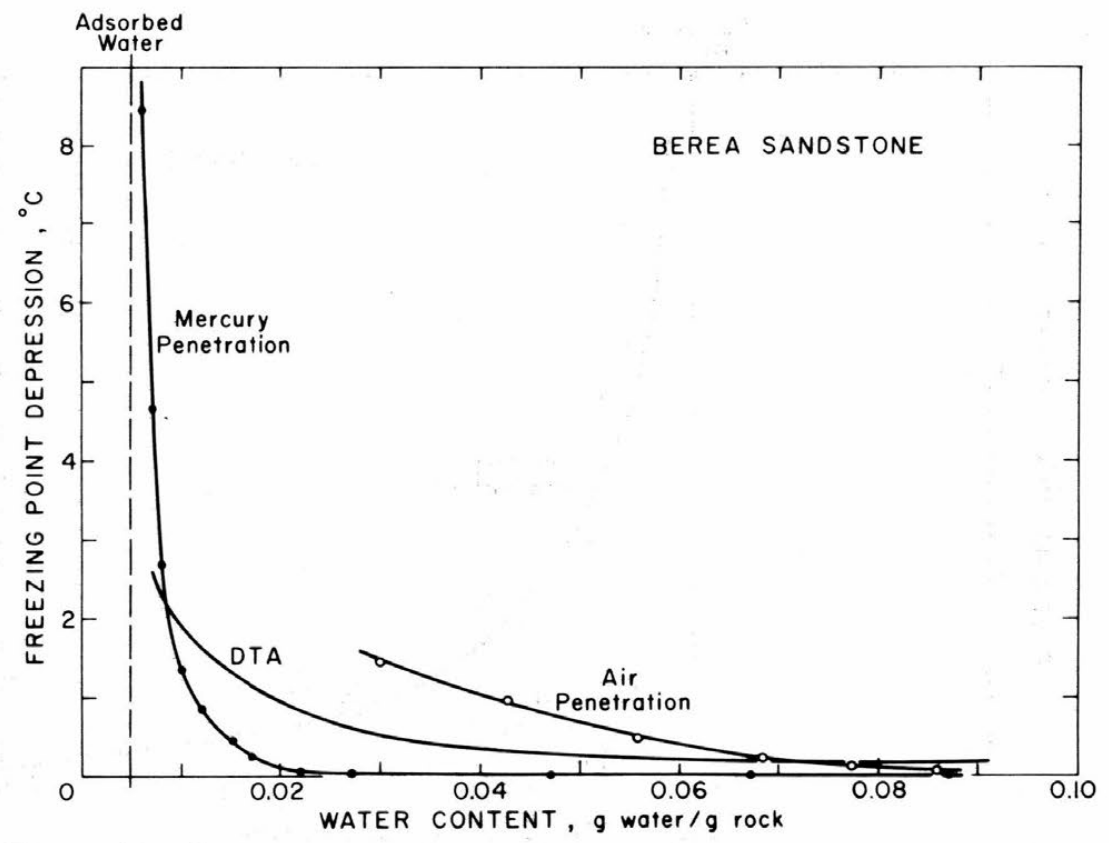

Figure 17. Freezing point depression as a function of water content for Berea sandstone.

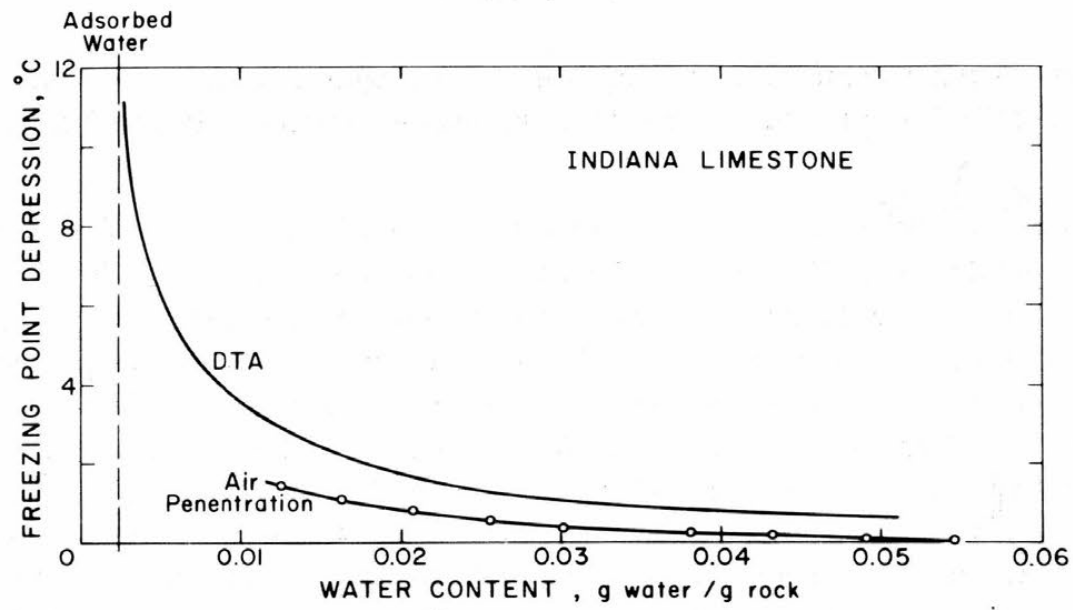

Figure 18. Freezing point depression as a function of water content.for Indiana limestone.

\section{Comparison of calculated and measured freezing characteristics}

The freezing characteristics calculated from air penetration and mercury penetration measurements are compared with those measured directly by DTA in Figures 17, 18 and 19.

Looking first at the air penetration results, the calculated characteristics show little quantitative agreement with the DTA curves; the calculated curve parallels the DTA curve for Indiana limestone, but not for Berea sandstone. Calculated freezing point depressions are less than the measured values for Indiana limestone and Barre granite, but generally greater than the measured values for Berea sandstone.

The mercury penetration results for Berea sandstone give freezing point depressions which generally are smaller than the measured values, but the calculated and measured characteristics follow the same trend. 


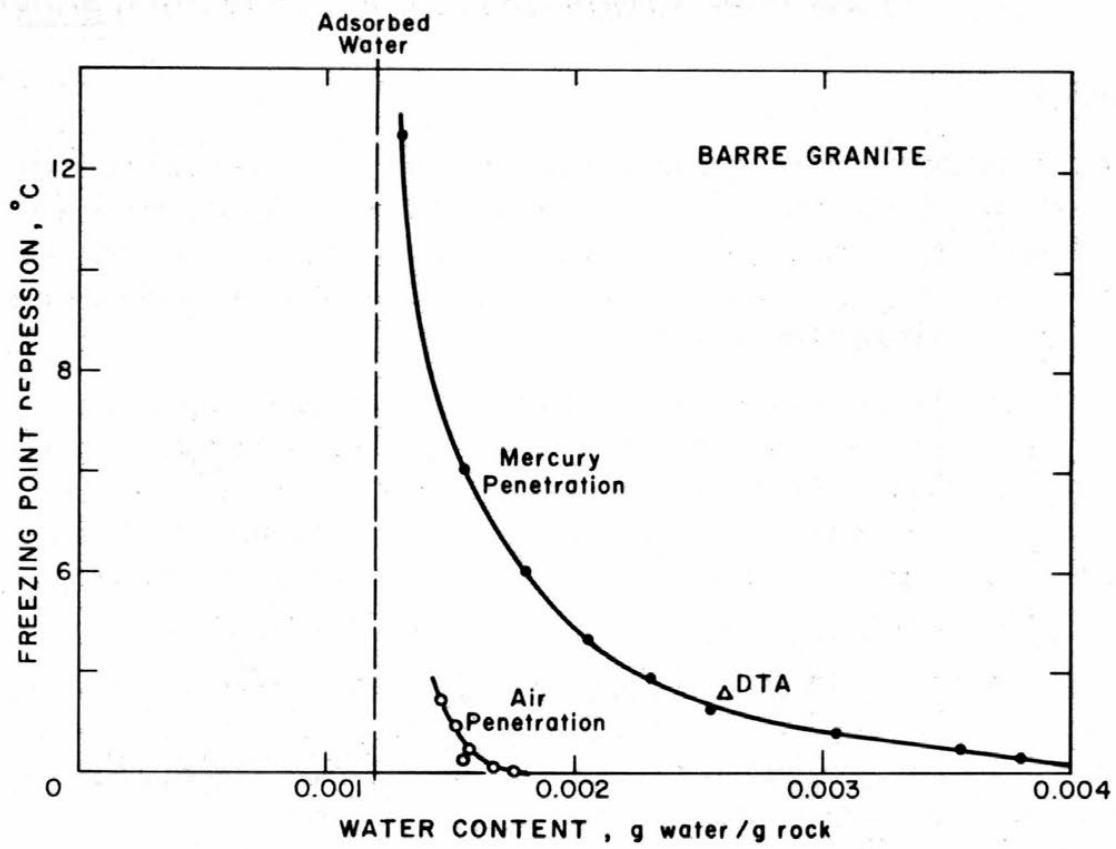

Figure 19. Freezing point depression as a function of water content for Barre granite.

The adsorbed water content, which appeared to represent an asymptotic limit for the DTA curves (Part A) still fills that role for the freezing characteristics calculated from mercury penetration data.

Before any conclusions can be drawn regarding the usefulness of calculated freezing characteristics, the probable reliability of the DTA curves has to be considered. The curves shown give actual measured values, and in view of the consistent discrepancy between measured and calculated curves for high water contents it is worth considering whether a zero error in temperature could have occurred. The temperature sensing thermocouples of the DTA equipment were given "steady-state" calibrations at $0^{\circ} \mathrm{C}$, and a zero check of the apparatus was made on every run immediately prior to the first phase change. : It is possible that there may have been some error due to conduction along the thermocouple wire, which was subject to steep temperature gradients during cooling runs. : However, the limited DTA data give no indication of a correlation between freezing point depression and cooling rate, which might be expected if conduction along the thermocouple wire is a source of error. The DTA records for warming runs, in contrast to those for cooling runs, show no distinct temperature for pore water phase change. They indicate that melting begins at temperatures well below $0^{\circ} \mathrm{C}$ and continues progressively up to $0^{\circ} \mathrm{C}$. In saturated specimens of sandstone and limestone a significant amount of melting takes place at $0^{\circ} \mathrm{C}$. The other possible source of error in the DTA curves concerns the water contents. The water contents plotted are believed to be accurate values of the average water content of the sample, but at low water contents there is no absolute guarantee that the water was uniformly dispersed throughout the sample, even though appropriate precautions were taken.

Taking into account the possibility of error in the DTA results and the apparent differences between freezing and thawing events, the mercury penetration data give plausible calculated freezing characteristics, but further verification by calorimetry seems desirable. 


\section{Conclusions}

Air penetration measurements in a standard 15-bar pressure membrane apparatus do not provide a good guide to the freezing characteristics of rocks. The maximum pressure reached corresponds to a temperature of only $-1.5^{\circ} \mathrm{C}$ and, on the basis of the present tests, the agreement with DTA results is poor. : However, with high pressure apparatus and improved technique it ought to be possible to obtain better results.

The freezing characteristics calculated from mercury penetration data are quite encouraging, although they cannot yet be accepted as completely valid on the basis of presently available data. Equipment and technique for mercury penetration measurements are well developed, and the data produced are of broad interest in rock mechanics. The measurements described here were made originally to obtain pore size distribution for general descriptive purposes, so that freezing characteristics were obtained without direct experimental cost.

Mercury porosimeter measurements are offered as an analytical service by specially equipped commercial laboratories. This is convenient when relatively few samples have to be processed, but results furnished by commercial contract for the present study contained a gross error and some evidence of minor carelessness.

It is concluded that, for a simple first estimate of freezing characteristics of rocks, water adsorption and mercury penetration measurements may be employed.

\section{ELECTRICAL CONDUCTIVITY MEASUREMENTS}

The foregoing investigations (Parts A and B) provide detailed information on freezing characteristics of pore water from $0^{\circ} \mathrm{C}$ down to about $-15^{\circ} \mathrm{C}$, but the methods used are unsuitable for investigation of the state of the pore water at very low temperatures, and an alternative technique must be sought.

Although little is known about the electrical properties of common rock-forming silicates, they are believed to be good insulators, and the conductivity of typical silicate rock at normal temperatures is thought to be controlled by the water contained in the rock (Keller, 1966, 1967). If this is the case, then electrical conductivity ought to provide a sensitive means of exploring the amount and condition of unfrozen water at low temperatures, since the bulk conductivity of ice is low relative to that of water. Experimental results show that freezing of pore water does, in fact, cause a sharp drop in the electrical conductivity of wet rocks (Parkhomenko, 1967; Dumas, 1962).

One objection to the adoption of electrical measurements as a means of studying pore water over a range of temperatures is that the dielectric behavior of water adsorbed or dispersed in porous media is still imperfectly understood, so that major research effort is required if results are to be truly intelligible. : However, this objection can be minimized if an electrical parameter is regarded as a semi-empirical index which is to be measured as a function of temperature in order to define broad trends and discontinuities.

The following measurements should be regarded simply as a first step towards the investigation of pore water at low temperatures. : Even with very good apparatus, accurate measurement of all components of the complex dielectric constant for wet rock involves appreciable experimental problems (Scott et al., 1967), major difficulties being shielding and correction for stray fields and electrode polarization (Hoekstra and O'Brien, 1969). Pilot tests gave direct evidence of these problems when d-c measurements and capacitance measurements were made, and for the 
Table V. General properties of test specimens.

\begin{tabular}{lccccc}
$\begin{array}{c}\text { Rock } \\
\text { type }\end{array}$ & $\begin{array}{c}\text { Bulk dens- } \\
\text { ity }(\mathrm{dry}) \\
\left(\mathrm{g} / \mathrm{cm}^{3}\right)\end{array}$ & $\begin{array}{c}\text { Effective } \\
\text { porosity } \\
(\%)\end{array}$ & $\begin{array}{c}\text { Surface } \\
\text { area } \\
\left(\mathrm{m}^{2} / \mathrm{g}\right)\end{array}$ & $\begin{array}{c}\text { Pore } \\
\text { diameter } \\
(\text { microns })\end{array}$ & $\begin{array}{c}\text { Grain } \\
\text { size } \\
(\mathrm{mm})\end{array}$ \\
\hline Barre granite & 2.64 & 0.69 & 0.105 & $0.005-100$ & $2-4$ \\
Berea sandstone & 2.13 & 19.8 & 1.25 & $0.005-200$ & $0.1-0.2$ \\
Indiana limestone & 2.29 & 14.1 & 0.654 & $0.005-200$ & $0.2-1.0$ \\
Ice & 0.90 & & & $\approx 500$ (bubble diam) & $\approx 1.0$ \\
\hline
\end{tabular}

final tests only the apparent a-c conductivity at a frequency of $10^{4} \mathrm{~Hz}$ was measured as a function of temperature. This was convenient, as it permitted rapid measurements to be made on samples whose temperature was changing continuously.

\section{Procedures}

Rock specimens were cut from clean quarried blocks with diamond tools, using only clean water as cutting fluid. : Care was taken to avoid contamination after machining, and clean cotton gloves were worn when handling the samples. : Ice samples were prepared by packing sieved ice grains into a vibrated mold, saturating with degassed distilled water, and freezing (see Hawkes and Mellor, in press). General properties of the test specimens are given in Table V.

Equivalent conductivity was measured on a Wayne Kerr impedance bridge (transformer ratio arm bridge, type B221A) with an ESI a-c generator-detector (type 861A). : Running checks on frequency were made with a frequency counter (TSI Universal Counter, Model 361). Measurements were made at only one frequency $\left(10^{4} \mathrm{~Hz}\right)$, since sample temperature was changing continuously, and three samples were tested simultaneously. In the early pilot tests both conductance and capacitance were recorded, but it appeared that the capacitance readings were of doubtful value for the sample geometry and the type of cell used.

The test specimens were $2.57 \mathrm{~cm}$ in diameter and $5.11 \mathrm{~cm}$ long. : The ends of the rock cylinders were carefully primed with silver paint, which was applied when the rock temperature was about $30^{\circ} \mathrm{C}$ to evaporate the butyl acetate carrier before it could penetrate the rock appreciably. Aluminum disks, which acted as electrodes and sample supports, were tacked on to the primed ends with conducting silver epoxy adhesive.

The Lucite cell which carried the test samples is shown in Figure 20. The electrodes were spring loaded to assure positive contact during thermal straining, and a space for desiccant was provided. Each sample was surrounded by an air space and temperature was measured in this annulus between the sample and the cell wall (thermocouples cemented directly into the samples proved troublesome). The cell itself was placed inside a large Dewar flask, where it was supported against the walls by soft rubber pads (Fig. 21).

For tests on ice, the electrode consisted of a disk of $0.4 \mathrm{~mm}$ brass mesh lightly frozen onto the ice, a disk-shaped pad of find steel wool, and an aluminum disk. This sandwich was gently, but firmly, compressed by the electrode spring.

Tests on rock were made both with the material completely saturated and as dry as possible. The rocks were saturat ed by placing diied samples under vacuum for 24 hours, then running in degassed distilled water and maintaining the vacuum for a further 24 hours. To prepare the rocks 


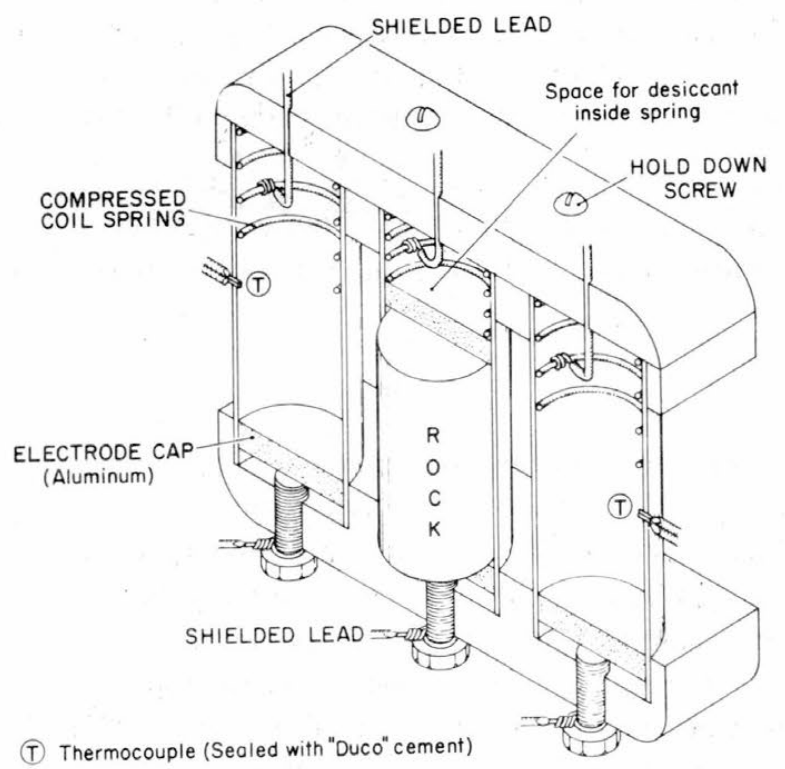

Figure 20. Test cell used for low temperature electrical conductivity measurements.

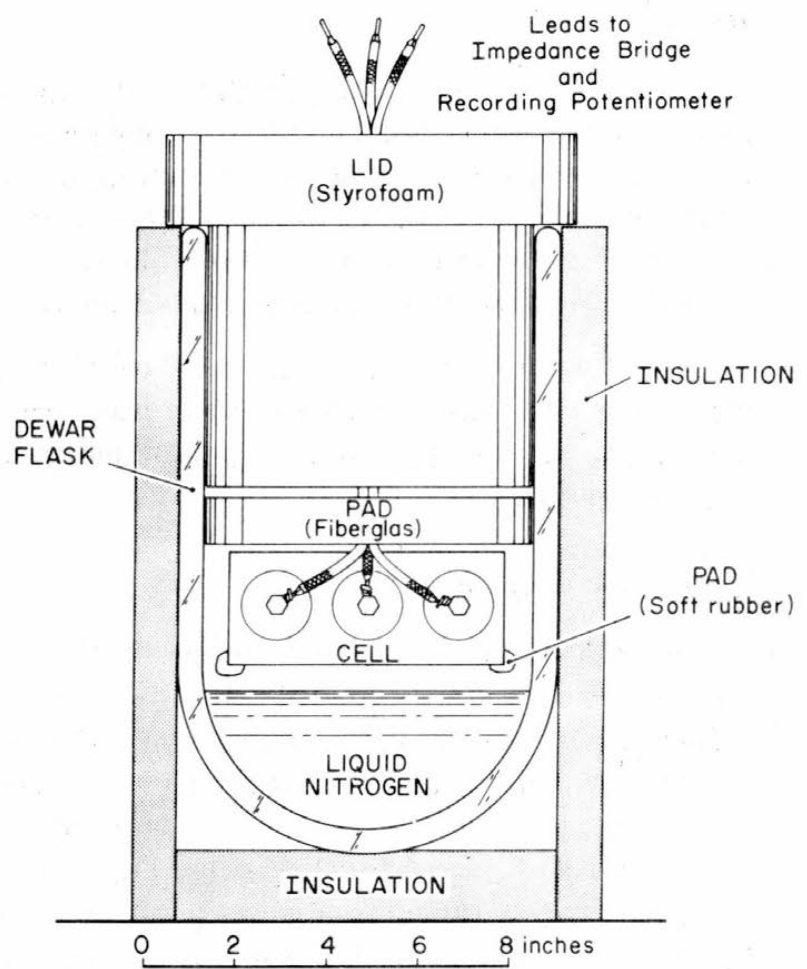

Figure 21. Arrangement of test cell in Dewar flask.

which here are called "dry," air-dry samples were placed in an oven at $50^{\circ} \mathrm{C}$ for 24 hours, then transferred to a $200^{\circ} \mathrm{C}$ oven for 20 minutes, and finally loaded into the cell with a charge of anhydrous calcium sulfate desiccant while still hot from the $200^{\circ} \mathrm{C}$ oven. This procedure does not remove adsorbed water completely, but it was the best that could be done under the circumstances. In the early tests, before desiccants were used, it was found that after simple oven drying conductivity fluctuated considerably with changes in the relative humidity of the electrical laboratory, especially in the case of the limestone, which appeared to be hygroscopic.

The test cell was cooled by nitrogen evaporating from a pool of liquid nitrogen (Fig. 21). The cooling rate was adjusted crudely by varying the level of the liquid nitrogen pool. The cell was warmed by conduction through the Dewar enclosure, and warming rate was moderated in the low temperature range by a shallow pool of liquid nitrogen. Cooling and warming rates were not permitted to exceed $20^{\circ} \mathrm{C} / \mathrm{hr}$. Check readings were made with steady temperature after the Dewar had been stored overnight in various cold rooms. The cell was recycled through some parts of the temperature range to provide a check. At the lowest temperatures it was necessary to saturate a covering pad of loose glass fiber (Fig. 21) with liquid nitrogen in order to cool the samples to the limit.

Sample temperature was measured by copper-constantan thermocouples, which were encased in beads of cement to produce a thermal lag similar to the lag in the interior of the rock samples. Temperatures were recorded on a potentiometric-input strip chart recorder (Moseley model 7100B). Calibrations were made in an ice bath and in liquid nitrogen, and against mercury-in-glass thermometers at -10 and $-35^{\circ} \mathrm{C}$. 


\section{Results}

Equivalent conductivity, or dielectric loss, is given as a function of temperature for Barre granite, Indiana limestone and Berea sandstone in Figures 22, 23 and 24, respectively. Data for two samples of fine-grained polycrystalline ice are shown in Figures 25 and 26. In the Berea sandstone and the polycrystalline ice, conductivity became too small to measure for the size of sample used when temperature dropped below about $-125^{\circ} \mathrm{C}$. The same data are shown with logarithm of conductivity plotted against the reciprocal of absolute temperature in Figures $27-30$.

The bridge system was stable and reliable and conductivity readings were precise and reproducible. The weakest measurement was temperature. Errors from thermal lag between sensor and sample were minimized by making warming and cooling runs, and by keeping rates of temperature change low.

\section{Discussion of results}

At temperatures above $0^{\circ} \mathrm{C}$ the conductivity of saturated specimens is relatively high: at $25^{\circ} \mathrm{C}$ the mean values were $4.2 \times 10^{-5}, 3.5 \times 10^{-5}$ and $2.8 \times 10^{-6}(\mathrm{ohm}-\mathrm{cm})^{-1}$ for Berea sandstone, Indiana limestone and Barre granite respectively. Conductivity of the unfrozen saturated specimens varied with temperature at rates comparable with typical rates for the temperature dependence of electrolytes (Keller, 1967). The conductivity of saturated rock is commonly correlated with porosity by an empirical relation, known as Archie's law,* in which conductivity is proportional to porosity raised to a power $p$, where $p$ lies between about 1.3 and 2.2 (Keller, 1966, 1967; Parkhomenko, 1967). Keller (1967) gives representative values for the empirical constanis of the modified form of Archie's law for several rock types, but when the present dat a are substituted into the appropriate expressions the calculated values for pore water conductivity are $0.6 \times 10^{-3}$, $1 \times 10^{-3}$ and $10 \times 10^{-3}(\mathrm{ohm}-\mathrm{cm})^{-1}$ for Berea sandstone, Indiana limestone and Barre granite respectively. This spread of values suggests that for rocks which have been flushed and saturated with distilled water the specific surface area may have to be considered as a significant variable in addition to porosity.

At temperatures above $0^{\circ} \mathrm{C}$ the conductivity for dry specimens is much lower than that for saturated specimens, by almost 5 orders of magnitude for sandstone and limestone and by more than 3 orders of magnitude for granite. If the specimens were dried more thoroughly using vacuum methods, conductivity would undoubtedly drop still further.

As the temperature is lowered below $0^{\circ} \mathrm{C}$, most of the pore water in saturated rock frəezes, causing a sharp drop in conductivity; conductivity drops by a factor of approximately 20 in Berea sandstone and Indiana limestone, and by a factor of 4 in Barre granite. For polycrystalline ice, the conductivity of meltwater at $0^{\circ} \mathrm{C}$ was an order of magnitude higher than the conductivity of the original ice at $0^{\circ} \mathrm{C}$.

At approximately $-10^{\circ} \mathrm{C}$ the conductivity characteristic for polycrystalline ice (Fig. 25 and 26) shows a transition from strong temperature dependence between $0^{\circ}$ and $-10^{\circ} \mathrm{C}$ to a weak temperature dependence between $-10^{\circ} \mathrm{C}$ and $-35^{\circ} \mathrm{C}$. The curve for saturated Berea sandstone (Fig. 24) shows a discontinuity at approximately $-8^{\circ} \mathrm{C}$, but this break represents a change to stronger temperature dependence for temperatures lower than $-8^{\circ} \mathrm{C}$. A detailed plot of Figure 22 shows a slight step at $-8^{\circ} \mathrm{C}$ for wet Barre granite, but it is doubtful whether this is significant.

* $\quad \sigma / \sigma_{w} \quad$ a $n^{p} s^{m}$

where $\sigma$ is bulk conductivity, ${ } W$ is pore water conductivity, $n$ is porosity, $S$ is saturation coefficient, and $a, p$ and $m$ are constants. 


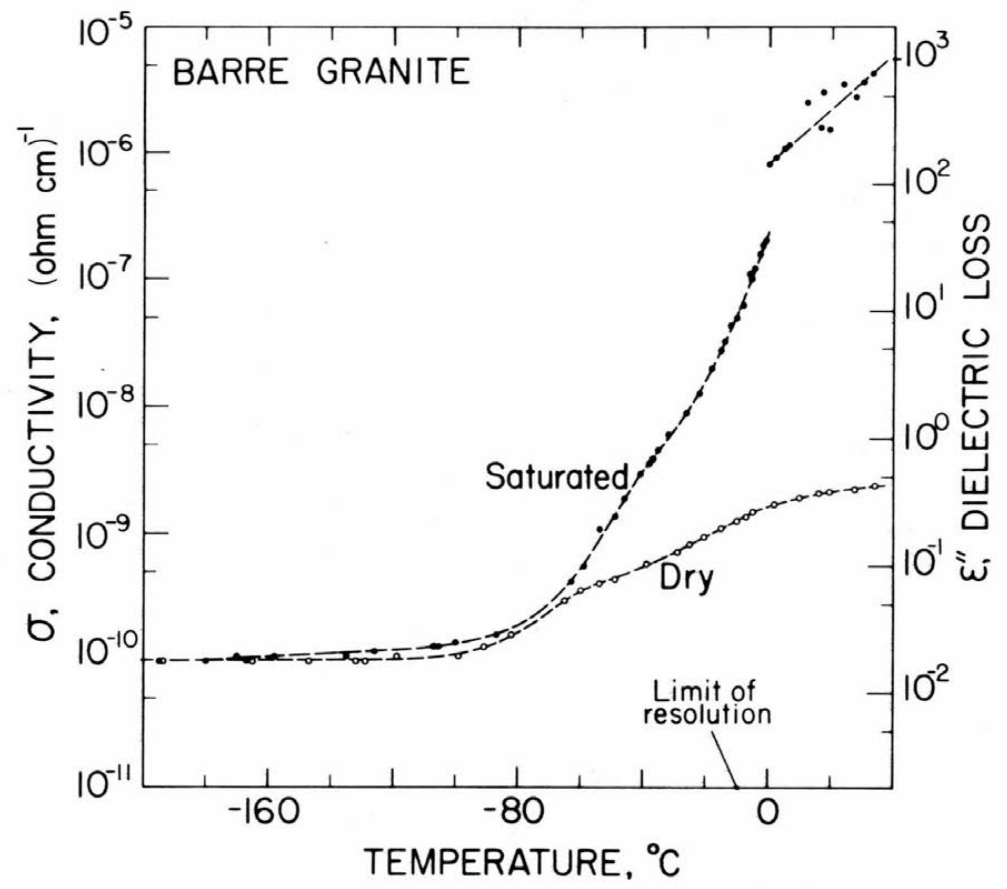

Figure 22. Conductivity at $10^{4} \mathrm{~Hz}$ as a function of temperature for Barre granite.

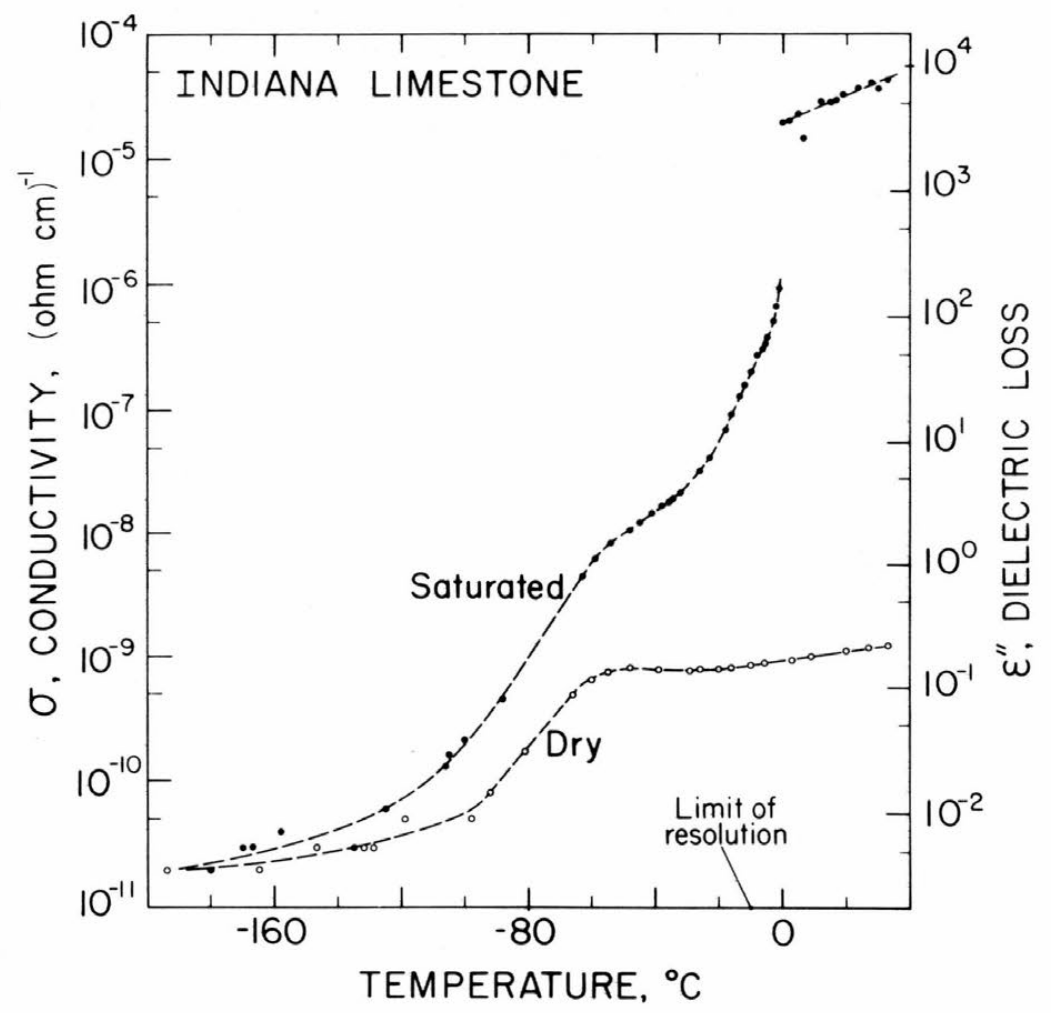

Figure 23. Conductivity at $10^{4} \mathrm{~Hz}$ as a function of temperature for Indiana limestone. 


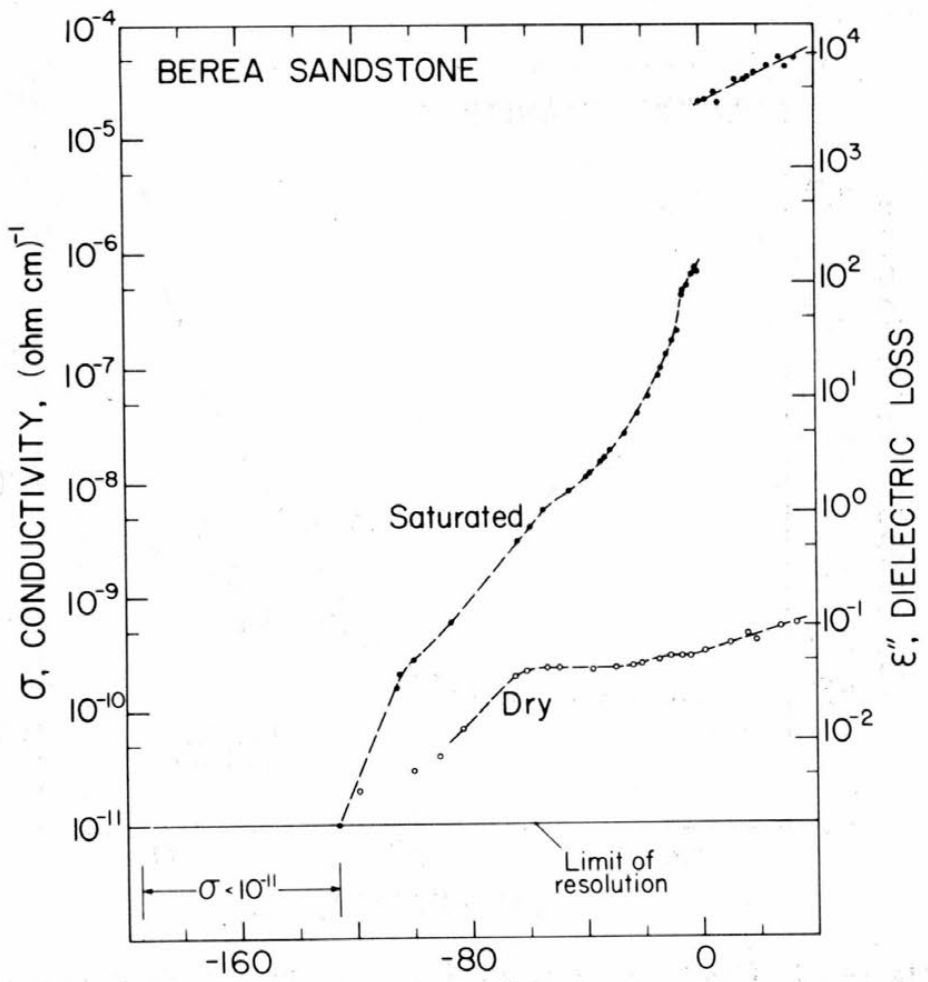

TEMPERATURE, ${ }^{\circ} \mathrm{C}$

Figure 24. Conductivity at $10^{4} \mathrm{~Hz}$ as a function of temperature for Berea sandstone.

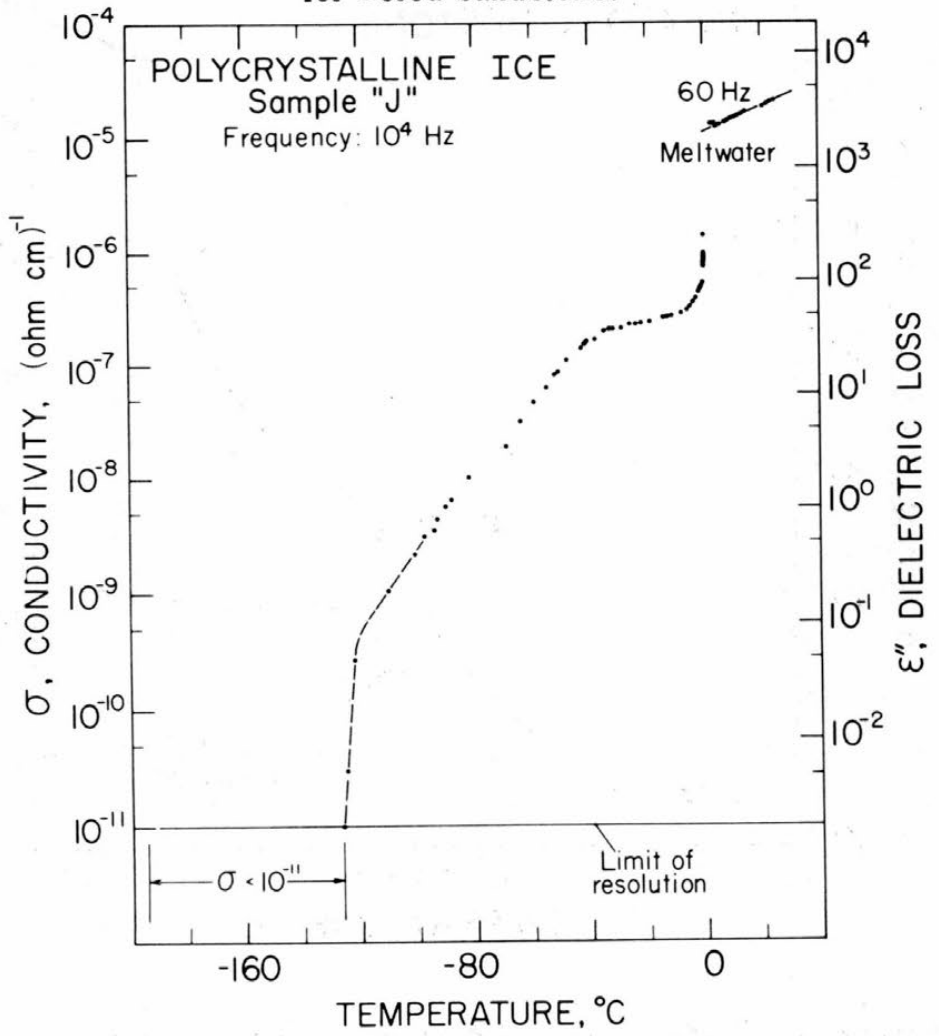

Figure 25. Conductivity at $10^{4} \mathrm{~Hz}$ as a function of temperature for fine-grained polycrystalline ice (sample $\mathrm{J}$ ). 


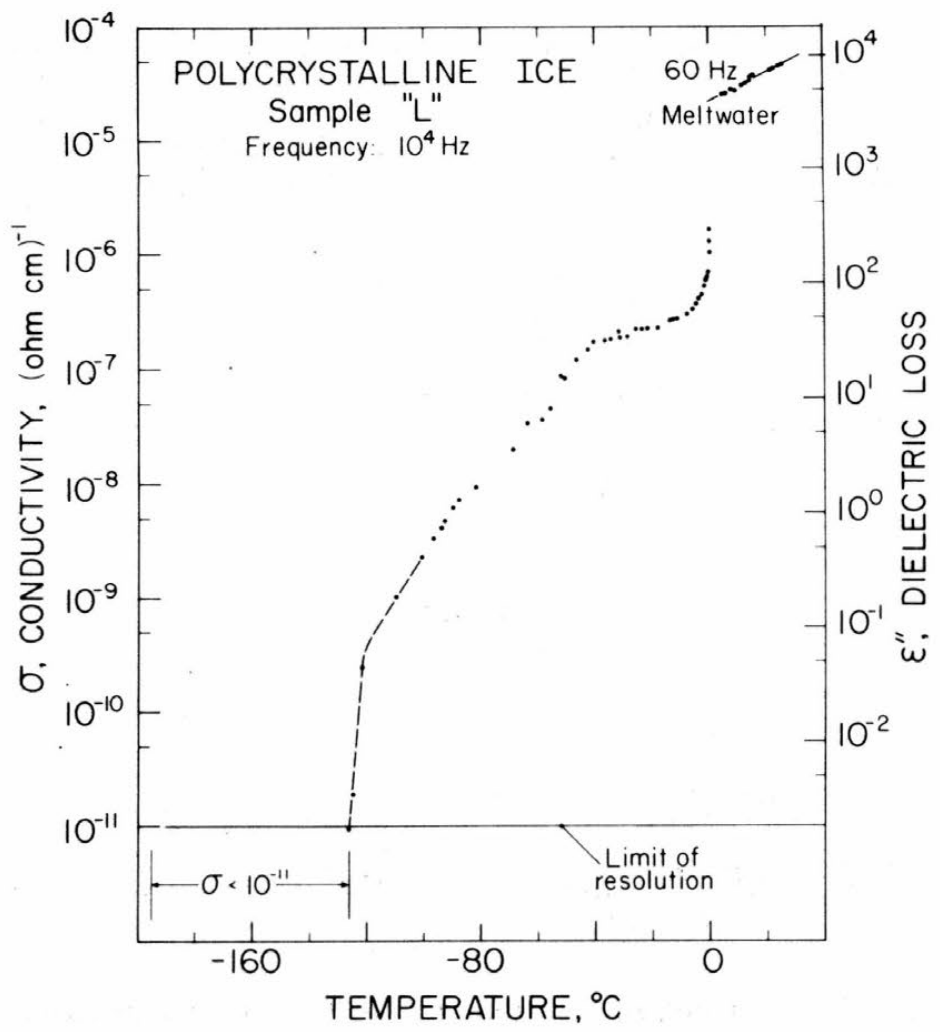

Figure 26. Conductivity at $10^{4} \mathrm{~Hz}$ as a function of temperature for fine-grained polycrystalline ice (sample L).

TEMPERATURE, ${ }^{\circ} \mathrm{C}$

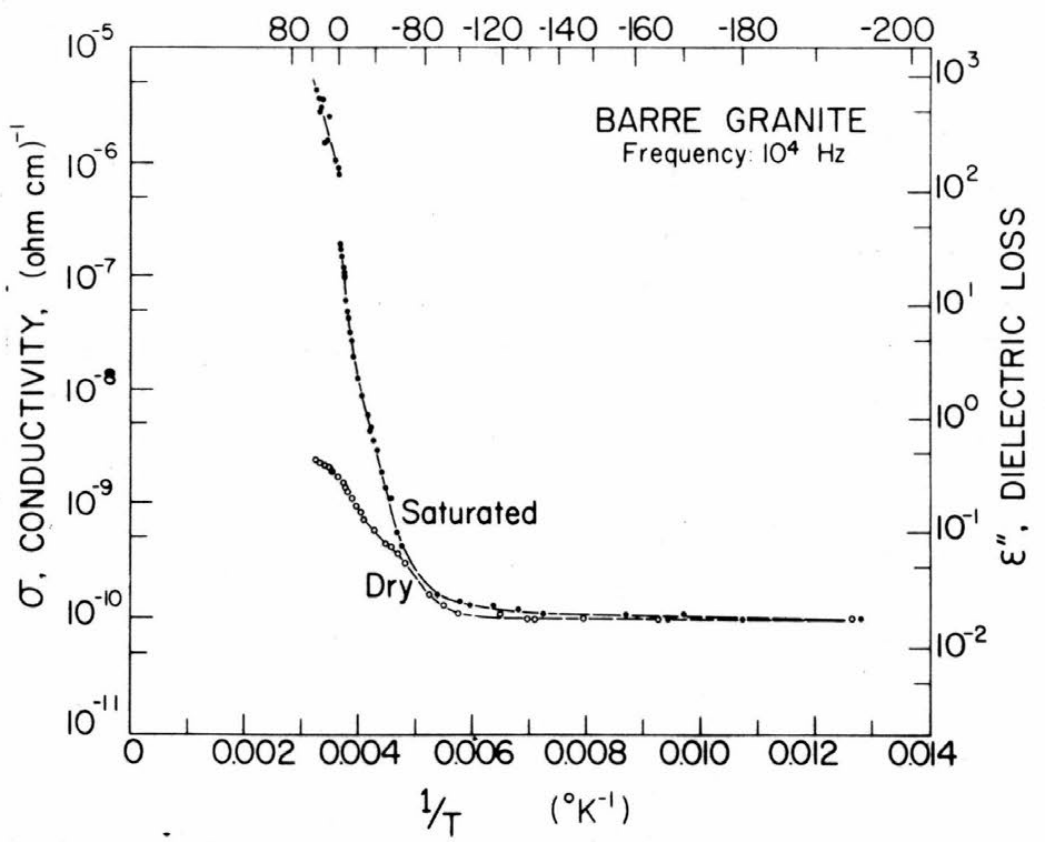

Figure 27. Conductivity plotted against 1/T for Barre granite. 
TEMPERATURE, ${ }^{\circ} \mathrm{C}$

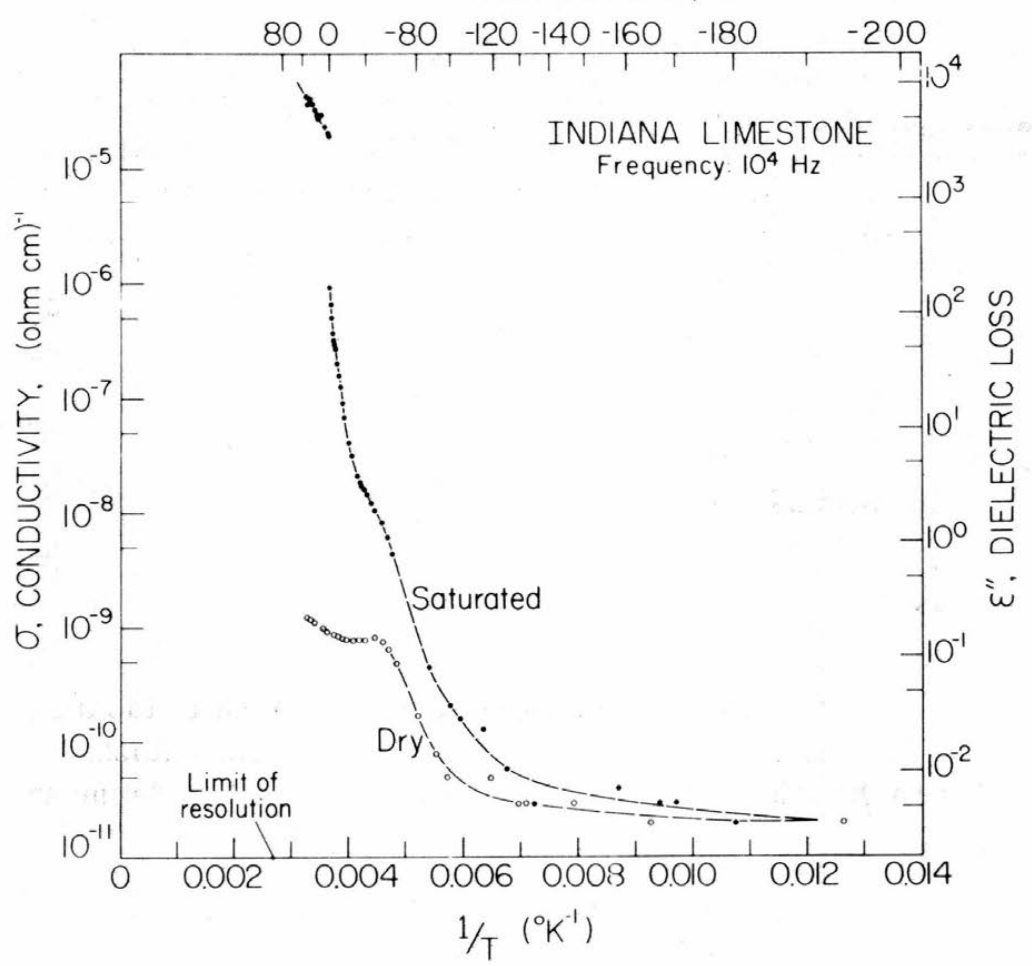

Figure 28. Conductivity plotted against $1 / \mathrm{T}$ for Indiana limestone. TEMPERATURE, ${ }^{\circ} \mathrm{C}$

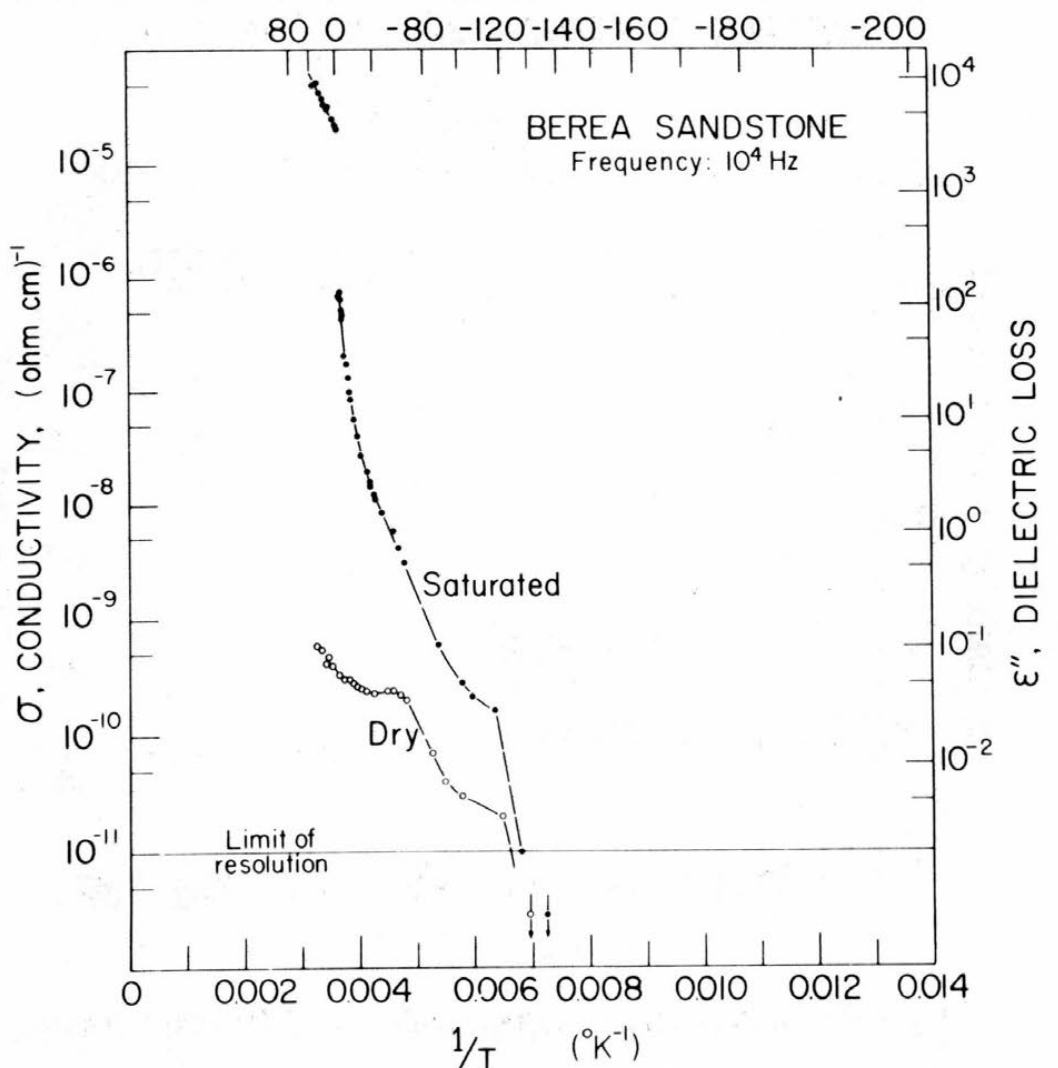

Figure 29. Conductivity plotted against 1/T for Berea sandstone. 
TEMPERATURE, ${ }^{\circ} \mathrm{C}$

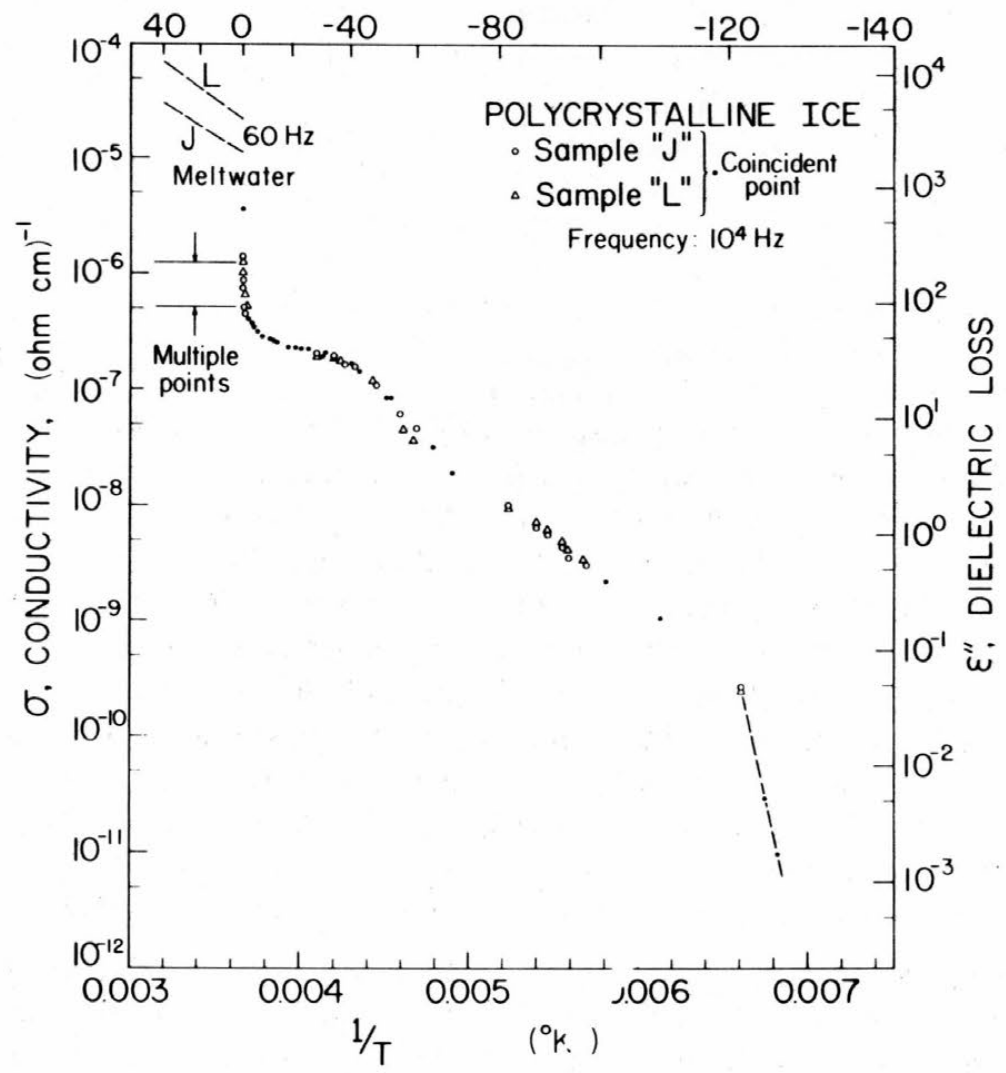

Figure 30. Conductivity plotted against $1 / \mathrm{T}$ for fine-grained polycrystalline ice.

At $-35^{\circ}$ to $-40^{\circ} \mathrm{C}$ the ice characteristic (Fig. 25 and 26) shows a distinct "knee," the temperature dependence of conductivity becoming considerably stronger for temperatures below $-40^{\circ} \mathrm{C}$. There is no direct reflection of this feature in the curves for rocks, although there is a converse trend towards weaker temperature dependence as temperature drops below $-35^{\circ} \mathrm{C}$ in wet Berea sandstone and wet Indiana limestone (Fig. 23 and 24). Curves for dry sandstone and limestone tend to "sag" to low values at $-35^{\circ}$ to $-40^{\circ} \mathrm{C}$.

At $-55^{\circ} \mathrm{C}$ to $-60^{\circ} \mathrm{C}$ the curves for sedimentary rocks (Fig. 23 and 24) show pronounced "knees" for both wet and dry specimens. There are similar, though more subdued, features in the curves for Barre granite, but they do not show clearly in the small scale plot of Figure 22.

Between $-70^{\circ}$ and $-80^{\circ} \mathrm{C}$ there is a small step-like discontinuity in the curve for ice, and a most remarkable "hump" in the curve for saturated wood (App. C, Fig. C1). There are no corresponding discontinuities for rocks, but below $-80^{\circ} \mathrm{C}$ the curves for Indiana limestone and Barre granite tend to limiting low temperature values of conductivity, with curves for wet and dry specimens converging to the same value of conductivity at $-195^{\circ} \mathrm{C}$.

The curves for Berea sandstone show no evidence of a discontinuity at $-80^{\circ} \mathrm{C}$, but below $-105^{\circ} \mathrm{C}$ the conductivity for saturated rock falls rapidly. Below $-125^{\circ} \mathrm{C}$ the conductivity of both wet and dry sandstone became too small for measurement with the size of specimens used. The curves for polycrystalline ice show a very sharp break at $-120^{\circ} \mathrm{C}$, with conductivity dropping abruptly until it became too small for measurement at temperatures below $-126^{\circ} \mathrm{C}$. 
Recognizing that pore water freezes progressively as temperature falls below $0^{\circ} \mathrm{C}$, Keller (1967) suggested that freezing of pore water should be regarded simply as an effective reduction of the pore space occupied by water for consideration of electrical conductivity down to $-60^{\circ} \mathrm{C}$. While this is undoubtedly an oversimplification of the true facts, it may give rough working estimates that are adequate for some practical purposes. : If effects of changes in pore water salinity (which enters Archie's law only as a first power) are neglected, then the ratio of conductivities for two different temperatures is equal to the ratio of unfrozen water contents for those temperatures raised to the power $p$, where $p \approx 2$. By this argument the drop in conductivity by a factor of 20 when pore water first freezes in Berea sandstone and Indiana limestone would be produced by reduction of unfrozen water content by a factor of $\sqrt{20}$, or about 4.5 , which is roughly the magnitude of the reduction shown by DTA and penetration studies in Parts A and B. For Barre granite the observed drop in conductivity by a factor of 4 after initial freezing would correspond to reduction of water content by a factor of 2 , which again is not too far from the observed drop in unfrozen water content. At $-60^{\circ} \mathrm{C}$ the ordinate between the extrapolated line for unfrozen saturated rock and the actual curve for the frozen rock gives factors for freeze-effect conductivity drop of 872 , 804 and 78 for Berea sandstone, Indiana limestone and Barre granite respectively. On Keller's assumption these factors would correspond to reductions in unfrozen water content by factors of 29.5, 28.3 and 8.83 respectively for sandstone, limestone and granite. The actual unfrozen water contents at $-60^{\circ} \mathrm{C}$ are not known, but since adsorbed water content appeared to define an asymptotic limit for unfrozen water in the studies described in Parts A and B, the ratio of adsorbed water to total water provides a first approximation. The values for this ratio are 19, 22, and 2.4 for Berea sandstone, Indiana limestone and Barre granite respectively.

Actually low temperature dielectric behavior of water dispersed in porous media is very complicated, being a subject of high current research interest. : The present single frequency conductivity measurements are wholly inadequate as a basis for discussion of conduction mechanisms, but they suffice to draw attention to certain temperatures and temperature ranges which may be of special interest. : Reviewing the significant temperatures listed at the beginning of this discussion, a number of observations may be made:

$0^{\circ}$ to $-10^{\circ} \mathrm{C}$. Temperature dependence for conductivity of impure polycrystalline ice is high in this range, and certain mechanical properties of the same type of ice similarly show temperature dependence. : Creep rate enhancement for ice is disproportionately high (Mellor and Testa, 1969), and strength of snow, ice and ice-bonded sand is strongly temperature-dependent above $-10^{\circ} \mathrm{C}$ (Mellor and Smith, 1965). These effects have been attributed to existence of a significant intergranular liquid-like layer above $-10^{\circ} \mathrm{C}$, and effects of typical contaminants have been considered (Mellor and Smith, 1965). The thickness of liquid-like interfacial water in frozen soils decreases sharply as temperature falls from $0^{\circ}$ to $-5^{\circ} \mathrm{C}$, and the mobility of unfrozen water is apparently much reduced below $-10^{\circ} \mathrm{C}$ (Anderson, 1968). In rocks there is a similar sharp drop in unfrozen water content possible below $-10^{\circ} \mathrm{C}$ (Parts $\mathrm{A}$ and $\mathrm{B}$ ).

$-35^{\circ}$ to $-40^{\circ} \mathrm{C}$. Low temperature differential thermal analysis on frozen clay soils has disclosed exotherms associated with phase changes in the interfacial water in this temperature range (Anderson, 1968).

$-55^{\circ}$ to $-60^{\circ} \mathrm{C}$. Hoekstra and Doyle (1969) made dielectric measurements on frozen montmorillonite at $10^{10} \mathrm{~Hz}$, and found at $-53^{\circ} \mathrm{C}$ a sharp break in slope on the plot of conductivity against reciprocal of absolute temperature.

$-80^{\circ} \mathrm{C}$. Below $-80^{\circ} \mathrm{C}$ the properties of interfacial water tend to acquire some of the characteristics of the solid state (Anderson, 1968), and the thickness of the interfacial film must tend 
to the low temperature limit of about $3 \AA$. It is possible for cubic ice (Ice Ic) to form by condensation from the vapor below $-80^{\circ} \mathrm{C}$ (Kumai, 1968).

$-120^{\circ}$ to $-130^{\circ} \mathrm{C}$. The glass transition temperature of water lies within, or close to, this range; the value determined by Miller (1969) is $-111^{\circ} \mathrm{C}$ and the value determined by Yannas (1968) is $-146^{\circ} \mathrm{C}$. The mechanical strength of frozen rocks appears to peak out near $-120^{\circ} \mathrm{C}$ (Mellor, in press).

\section{THERMAL STRAINS IN COLD ROCK}

Following the studies described in Parts A, B, and C, some measurements of thermal strain were made in the expectation that there would be strain discontinuities associated with phase change in the pore water. Initial measurements were made with an optical extensometer, but it soon became clear that this device lacked the sensitivity and stability needed for detection of strain discontinuities. A special recording dilatometer was then developed, and observations were made on three types of rock with various water contents.

Measurements made with the recording dilatometer were rapid "scanning" measurements, intended mainly for the detection of strain discontinuities. The inherent shortcomings of this rapid operating technique (chiefly temperature gradients in the test specimen) were accepted for the preliminary study, as it was necessary to obtain a broad picture before proceeding to more detailed work. The results obtained prove the merits of the apparatus and outline the general behavior of rocks subject to thermal strain at low temperatures, but time limitations on the overall project reatricted the scope of the study.

The recording dilatometer can be improved, principally by provision of better temperature control. The problem of low temperature thermal strain in rocks deserves fuller investigation, as it has an important bearing on thermal strains and frost deterioration in rocks, concrete, and ceramics.

\section{Preliminary tests}

The first measurements of thermal strain were made with a Gaertner optical extensometer, which consists of a pair of $10 \times$ telescopes (focusing distance 12 in.) mounted on an invar bar at a horizontal separation of $10 \mathrm{in}$. The micrometer telescope adjustment reads directly to $0.0001 \mathrm{in}$. The specimen was a rock cylinder, $1 \mathrm{in}$. in diameter by $11 \mathrm{in.} \mathrm{long,} \mathrm{to} \mathrm{which} \mathrm{a} \mathrm{pair} \mathrm{of} \mathrm{photograph-}$ ically printed crosshair targets were cemented at points along a generator $10 \mathrm{in}$. apart. The specimen lay horizontally in a cradle inside a special temperature control cabinet, the front of which was pierced with a pair of "peepholes" to permit sighting by the external extensometer. Specimen temperature was changed in steps, and each temperature was held for 3 or 4 hours before a measurement was made. Results obtained for air-dry specimens of Berea sandstone, Indiana limestone and Barre granite are given in Figures $31-33$.

Although considerable previous effort by other investigators had gone into development of operating technique for the optical extensometer, the results obtained were poor, even for observations on metal bar (see also Berg and Maffei, 1968). It was concluded that this optical extensometer was unsuitable for the detection of strain discontinuities, although it was later used to provide an interim calibration for a recording dilatometer. 


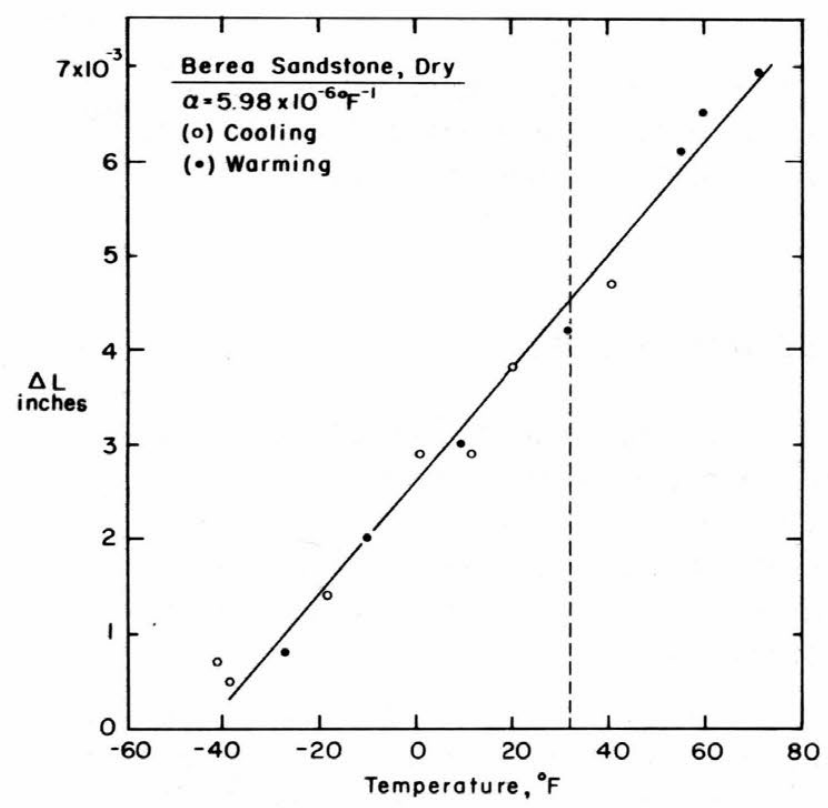

Figure 31. Optical extensometer results for air-dry Berea sandstone.

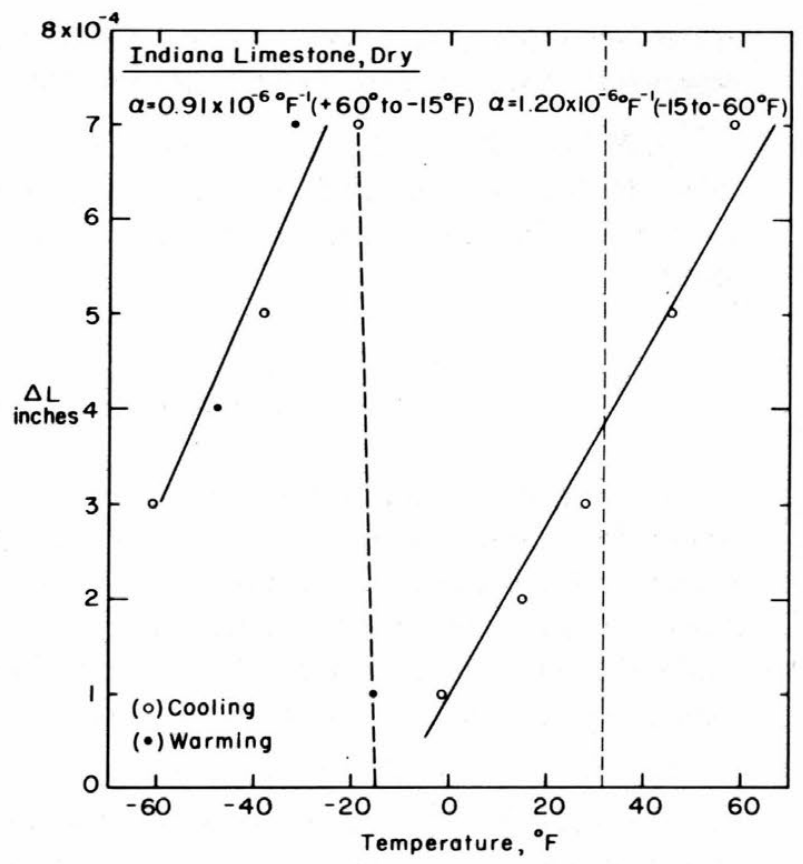

Figure 32. Optical extensometer results for air-dry Indiana limestone.

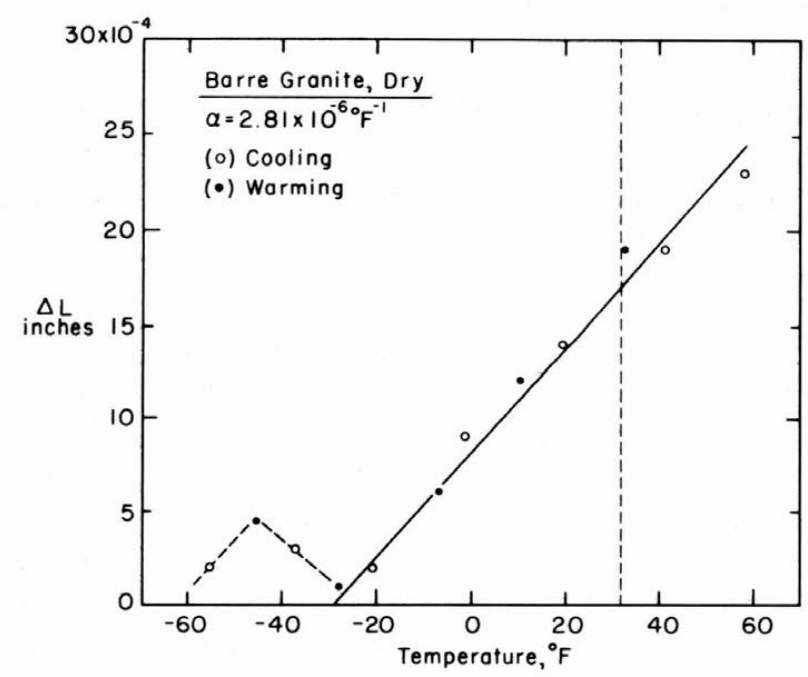

Figure 33. Optical extensometer results for air-dry

Barre granite.

\section{Recording dilatometer}

Probably the most satisfactory kind of device for thermal expansion measurements at low temperature is an optical lever dilatometer, which can be mounted in a cryostat and can have a sensitivity up to $10^{-8} \mathrm{~cm}$ (Bunton and Weintroub, 1968). However, for the present study it seemed impractical to build or acquire a suitable optical lever device in the time available for the work. The requirement was for an apparatus that would accept rock specimens with a minimum linear dimension of $1 \mathrm{in}$. (this size being dictated by the grain size of the rock), and would vary temperature in the range $+25^{\circ}$ to $-195^{\circ} \mathrm{C}$. 
The first device to be built consisted of a constant length baseplate and end frames, to which were attached a displacement transducer and spring-loaded push-rods. The specimen was a cylinder, $1 \mathrm{in.}$ in diameter by $11 \mathrm{in.} \mathrm{long,} \mathrm{and} \mathrm{it} \mathrm{lay} \mathrm{horizontally} \mathrm{inside} \mathrm{a} \mathrm{heavily} \mathrm{insulated} \mathrm{tubular}$ jacket, which itself was laid on rollers. Vapor from a tank of liquid nitrogen was piped into the jacket to cool the specimen, and warming was accomplished by heat conduction through the insulating jacket. Temperature was measured by a thermocouple taped onto the specimen, and temperature and displacement were recorded simultaneously as functions of time on a 2-channel potentiometric recorder. : The first problems arose from instability of the baseplate and end fiames, and they were replaced by a massive granite base. Difficulties were then encountered in the pushrod system and the penetrations of the insulating jacket, and the system was abandoned

The final design of the recording dilatometer is illustrated in Figure 34, and the experimental assembly is shown in Figure 35. The temperature enclosure consists of a metal Dewar flask, $4.5 \mathrm{in}$. inside diameter by approximately $15 \mathrm{in}$. deep, to which liquid nitrogen is added as coolant.

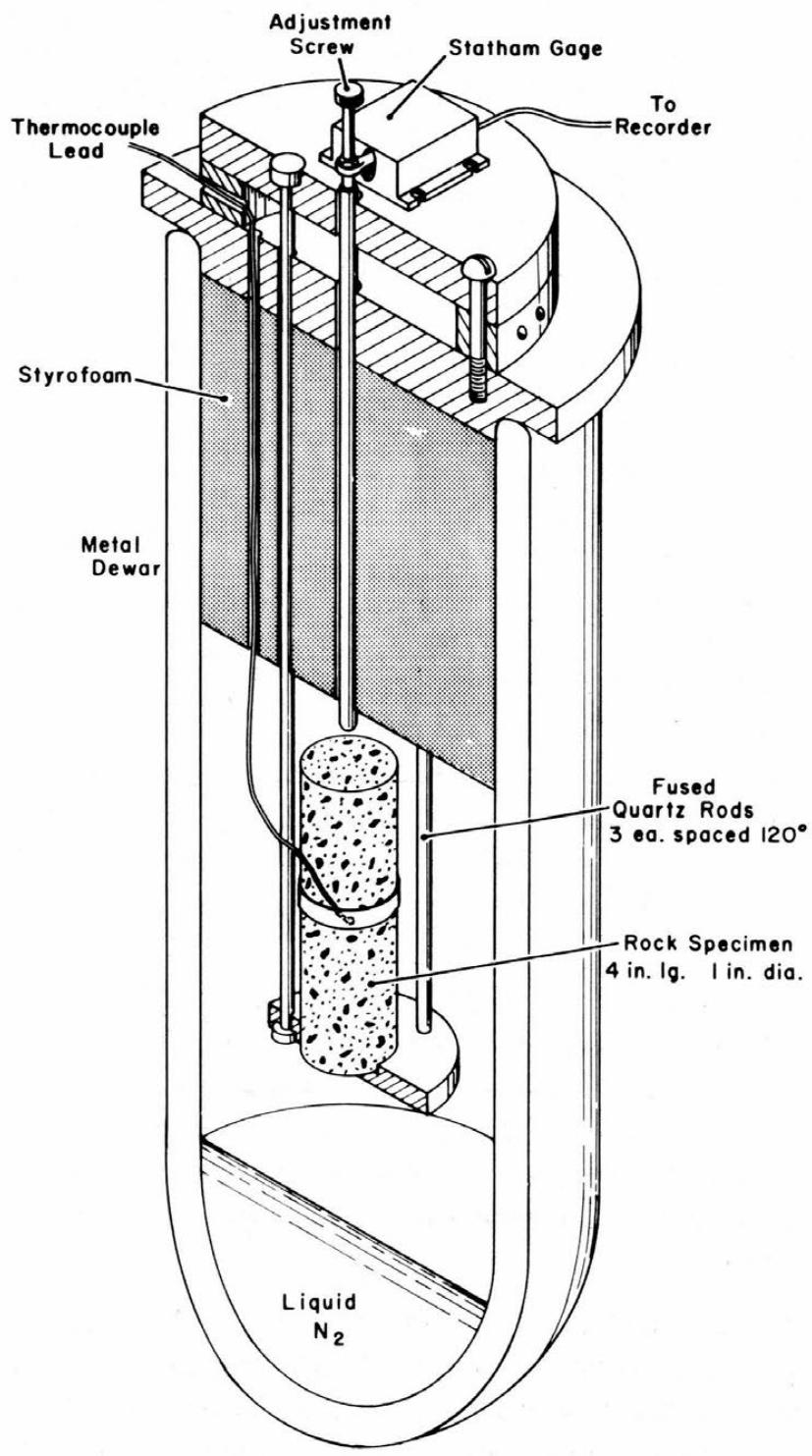

Figure 34. Recording dilatometer. 


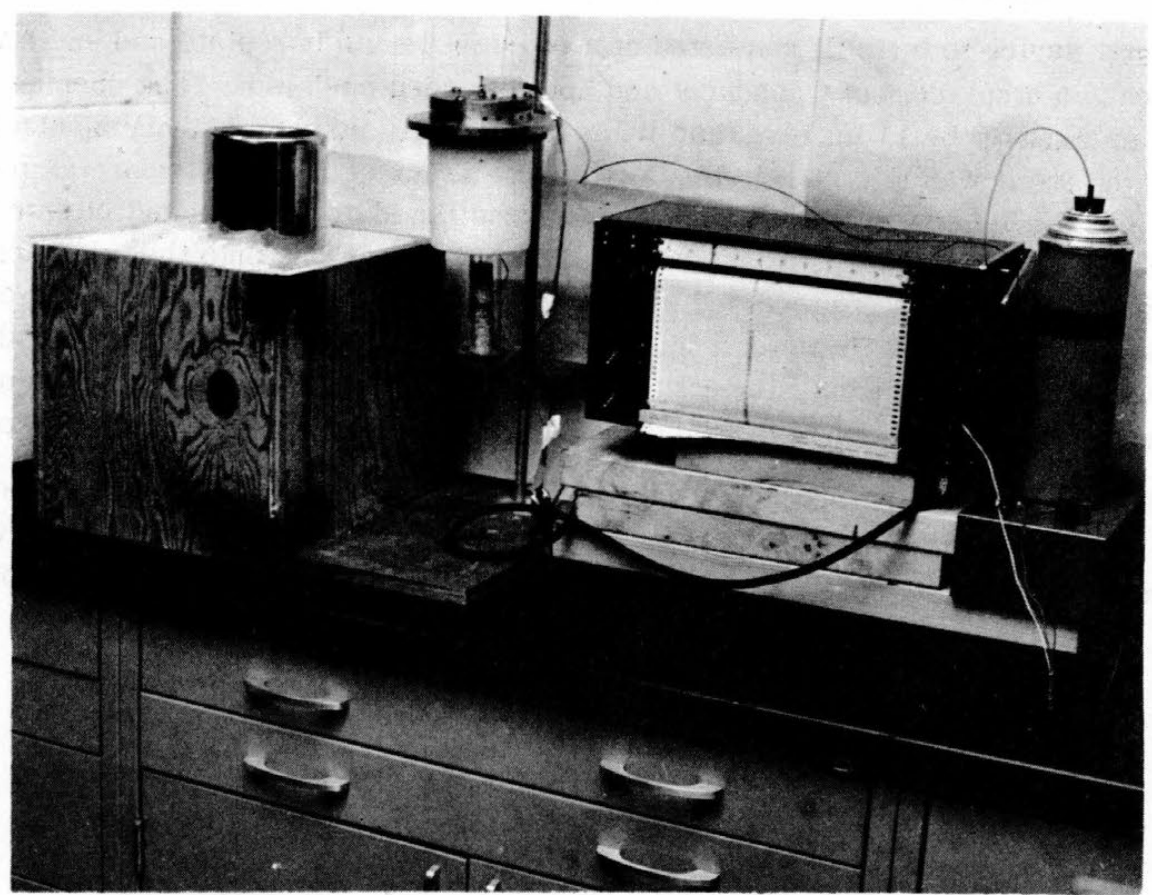

Figure 35. Recording dilatometer. From left to right: metal Dewar embedded in sand box; cap and plug, with suspended specimen; 2-channel recorder; recorder power supply surmounted by thermocouple ice-bath.

The Dewar is closed by a heavy steel lid and a plug of foamed polystyrene 5.25 in: deep. The steel lid is surmounted by a platform which supports the displacement transducer, a Statham type G7A unbonded strain gauge device. The rock specimen, 1 in. in diameter by 4 in. long, stands vertically on a stainless steel platform, which is suspended from the transducer platform by three rods of fused quartz (4 $\mathrm{mm}$ in diameter). A fourth fused quartz rod with hemispheric end caps slides freely at the center of the assembly, providing a push-rod to actuate the transducer as the test specimen changes length. The length of the suspension rods equals the length of the push-rod plus the length of the specimen. The device actually measures the change in length of the rock specimen relative to the change in length of fused quartz, which has a coefficient of expansion $\left(\approx 0.55 \times 10^{-6}{ }^{\circ} \mathrm{C}^{-1}\right)$ an order of magnitude smaller than coefficients for typical rocks. The parallel push-rod and suspension rods automatically compensate for the effects of temperature gradient through the plug.

To minimize vibration or disturbance of the apparatus, the Dewar was bedded in a box of Ottawa sand, and the whole experimental assembly was set on a rigid slate-topped bench in a concrete-floored basement laboratory. : Specimen temperature was sensed by a thermocouple taped at the mid-section; the specimen was wrapped with aluminum foil to assure reasonable uniformity of surface temperature and minimize evaporation or condensation, and it was jacketed with glass fiber insulation to minimize undesirable temperature gradients and to avoid high-frequency convective temperature fluctuations.

Temperature and displacement were recorded simultaneously as functions of time on a 2-channel potentiometric strip-chart recorder (Moseley 7100B), although an XY-plotter might be preferable. The potential sensitivity of the displacement transducer far exceeded the requirements for this work, and the gain was cut back to eliminate "noise" in the trace and to avoid frequent baseline shifts on the recorder. 


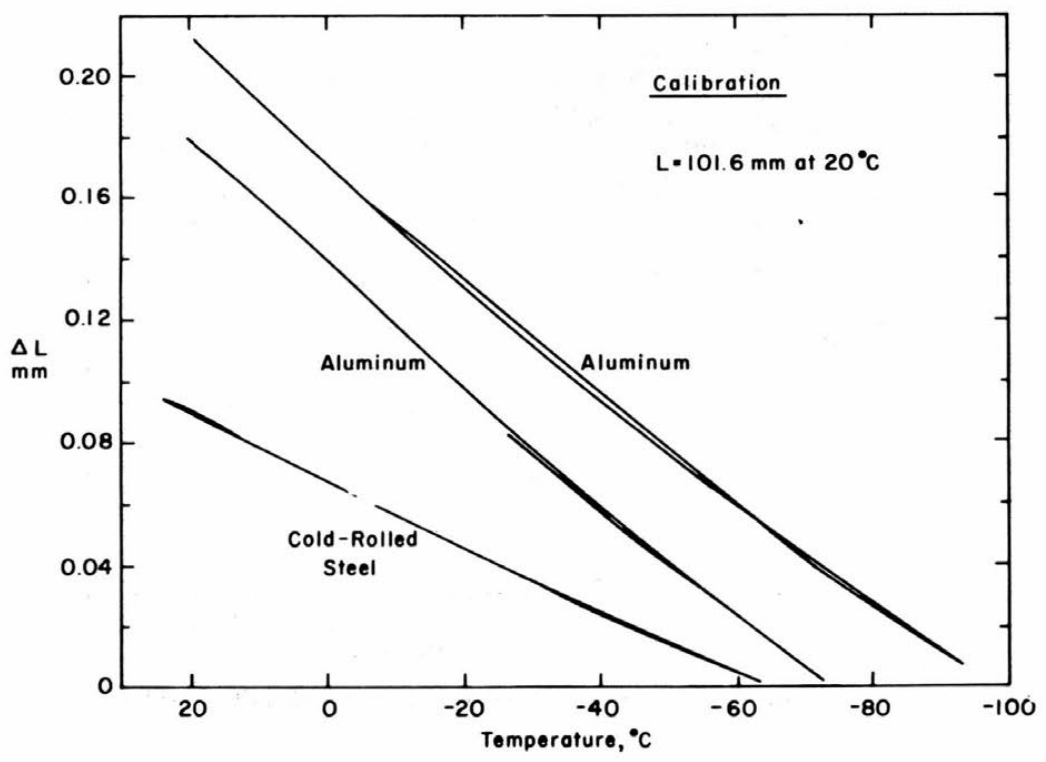

Figure 36. Calibration data from recording dilatometer.

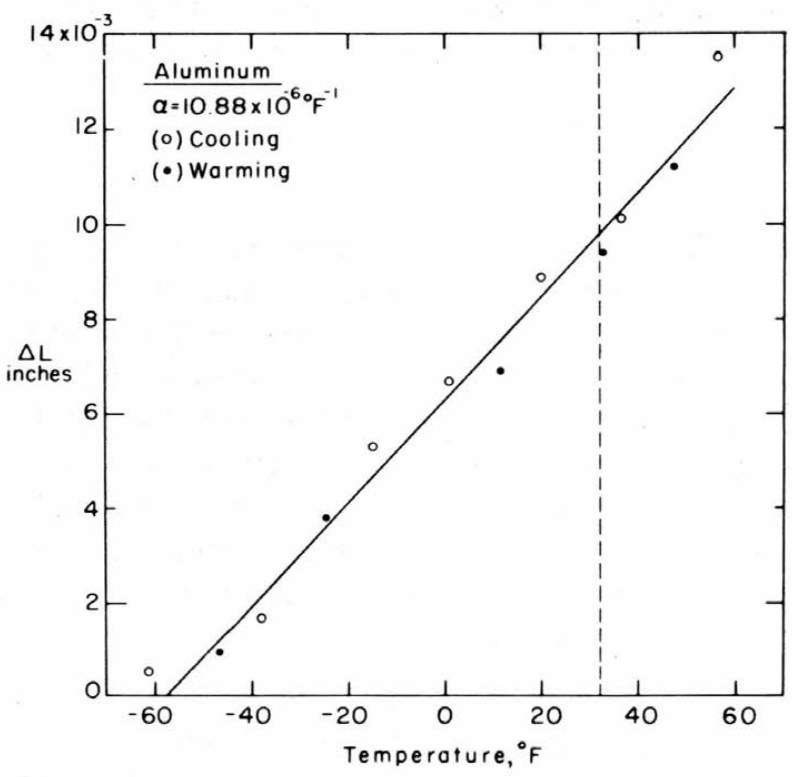

Figure 37. Calibration data from optical extensometer.

It was intended that the apparatus should be calibrated by running tests on a metal bar calibrated at the National Bureau of Standards, but to avoid undue delay an interim calibration was made by running tests on bars of aluminum and cold-rolled steel, which had themselves been tested previously in the optical extensometer apparatus (this apparatus was calibrated against a brass rod supplied by the National Bureau of Standards). Calibration data are given in Figures 36 -38. With a 6 -volt d-c supply to the transducer and a recorder setting of $10 \mathrm{mv}$ full scale (on a 10-in.-wide chart), the calibration factor was:

1 indicated $\mathrm{mv}=4.45 \times 10^{-4} \mathrm{in.}=1.13 \times 10^{-2} \mathrm{~mm}$. 


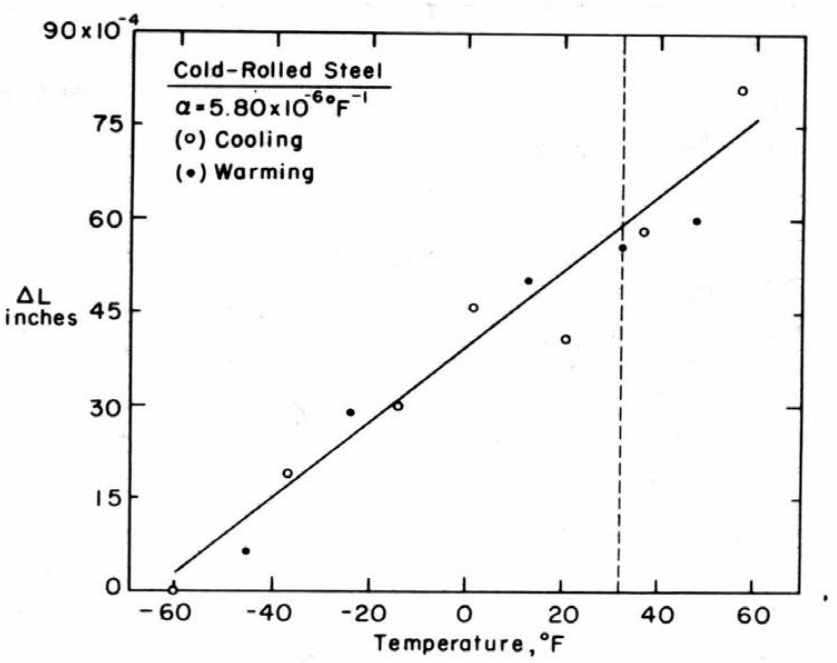

Figure 38. Calibration data from optical extensometer.

The main fault of the apparatus in its basic form was lack of temperature control. : This shortcoming could easily be remedied for future studies. One possibility would be to fit a cooling coil to circulate nitrogen vapor around the specimen, with an electrical resistance heating coil interwound.

\section{Test procedure}

Air-dry specimens were usually tested by loading them into the apparatus at room temperature, adding liquid nitrogen to the Dewar, and recording a cooling run followed by a warming run. Specimens with water contents close to saturation were usually prefrozen slowly under controlled conditions (see Mellor, in press, for details of freezing techniques). They were transferred to the dilatometer while still frozen, taken down to low temperature by liquid nitrogen, and a warming run was then recorded. : In some cases the liquid nitrogen was replenished before the pore water thawed so as to obtain additional runs, while in other cases the liquid nitrogen was replenished after the pore water had thawed at the end of the first warming run. : In the latter case, the refreezing of pore water on the second run occurred abruptly, in contrast to the slow freezing which occurred when specimens were prefrozen. :

In most cases the initial portion of the trace resulting from a freshly started cooling run was judged to be unreliable, since rate of temperature change was high $\left(\approx 2^{\circ} \mathrm{C} / \mathrm{min}\right.$ at first $)$ and stable temperature gradients in the specimen and its jacket had not been established. : Rates of temperature change also tended to be high $\left(\approx 1.2^{\circ} \mathrm{C} / \mathrm{min}\right)$ in the mid-section of a warming run when the liquid nitrogen pool boiled completely away before the specimen had reached a high temperature. Apparent hysteresis between warming and cooling runs is believed to be due to temperature gradients in the specimen; observation of consecutive warming and cooling runs ought to obviate errors from this source. :

During cooling runs, the rate of temperature change averaged $1.5^{\circ} \mathrm{C} / \mathrm{min}$ between $+13^{\circ}$ and $-13^{\circ} \mathrm{C}, 0.9^{\circ} \mathrm{C} / \mathrm{min}$ between $-13^{\circ}$ and $-41^{\circ} \mathrm{C}$, and $0.6^{\circ} \mathrm{C} / \mathrm{min}$ between $-41^{\circ}$ and $-71^{\circ} \mathrm{C}$. At the lowest temperatures, rates were lower than these. : During warming runs, the rate of temperature change averaged $1.2^{\circ} \mathrm{C} / \mathrm{min}$ between $-71^{\circ}$ and $-41^{\circ} \mathrm{C}$, and $0.7^{\circ} \mathrm{C} / \mathrm{min}$ between $-41^{\circ}$ and $-13^{\circ} \mathrm{C}$. 


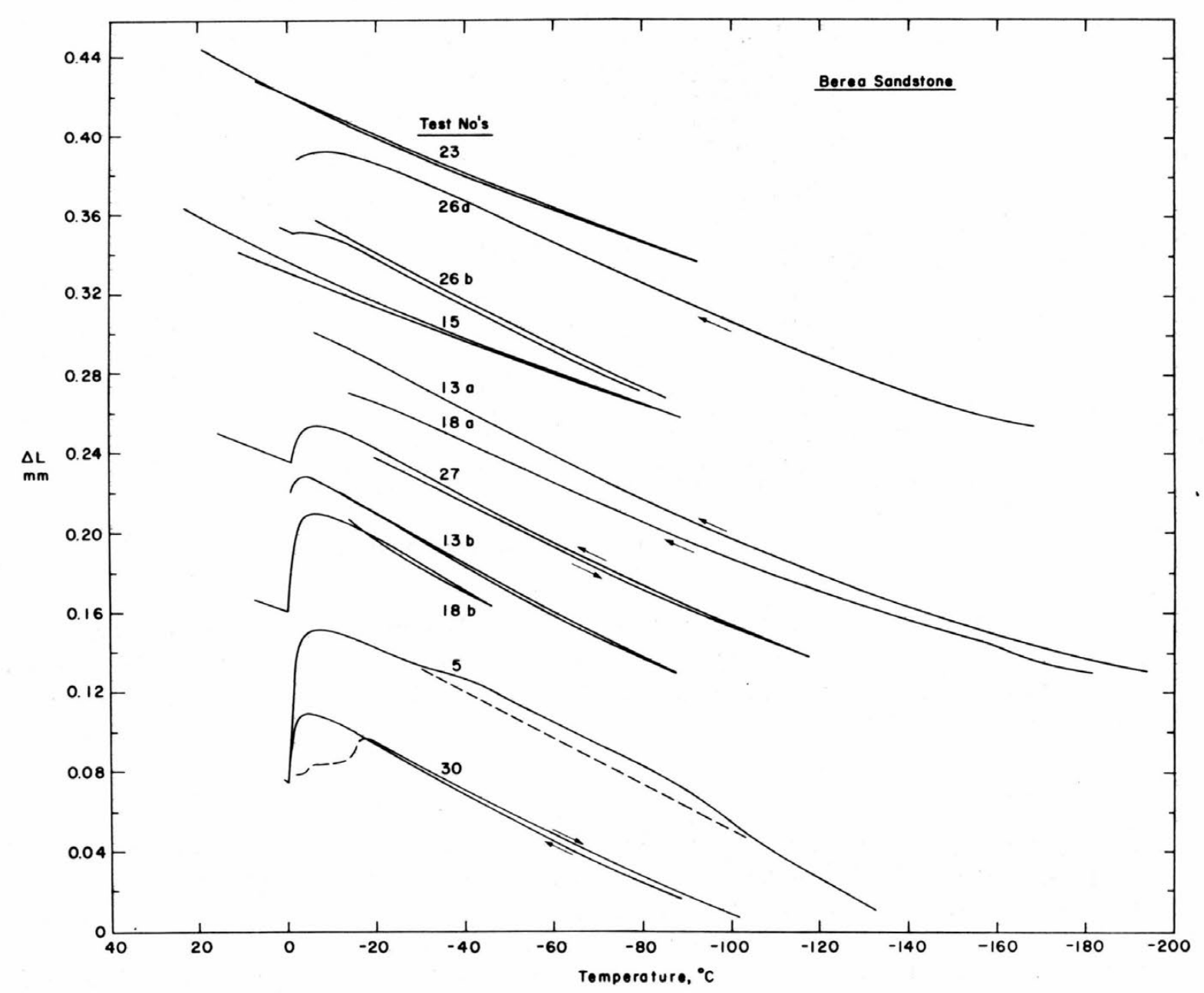

Figure 39. Thermal strain records for Berea sandstone.

\section{Results}

Results of the tests are given graphically in Figures 39-41, and a digest of numerical data is given in Table VI.

The first noticeable feature is that a strain discontinuity, or "step," exists for wet specimens. : In Figures 39-41 virtually all the strain "steps" shown are those measured during warming runs. : The step data for cooling runs have been omitted from the final plots, since in most cases the cooling rates were too high and results are confused by effects of steep temperature gradients in the test specimen. : However, the results which were obtained leave little doubt that the "freezing step" occurs at lower temperature than the "thawing step," and it tends to be steeper on the high temperature side.

In a thawing run the main step effect is spread over a fairly wide range of temperature: $10^{\circ} \mathrm{C}$ or more. In a warming run, the first evidence of melting effects may appear at a rather low temperature, say $-20^{\circ} \mathrm{C}$, presumably because of melting in the smallest pores which contain ice. Progressive melting effects are then evident up to a temperature slightly below $0^{\circ} \mathrm{C}$. This temperature, at which melting effects disappear, seems to correspond to the characteristic freezing point 


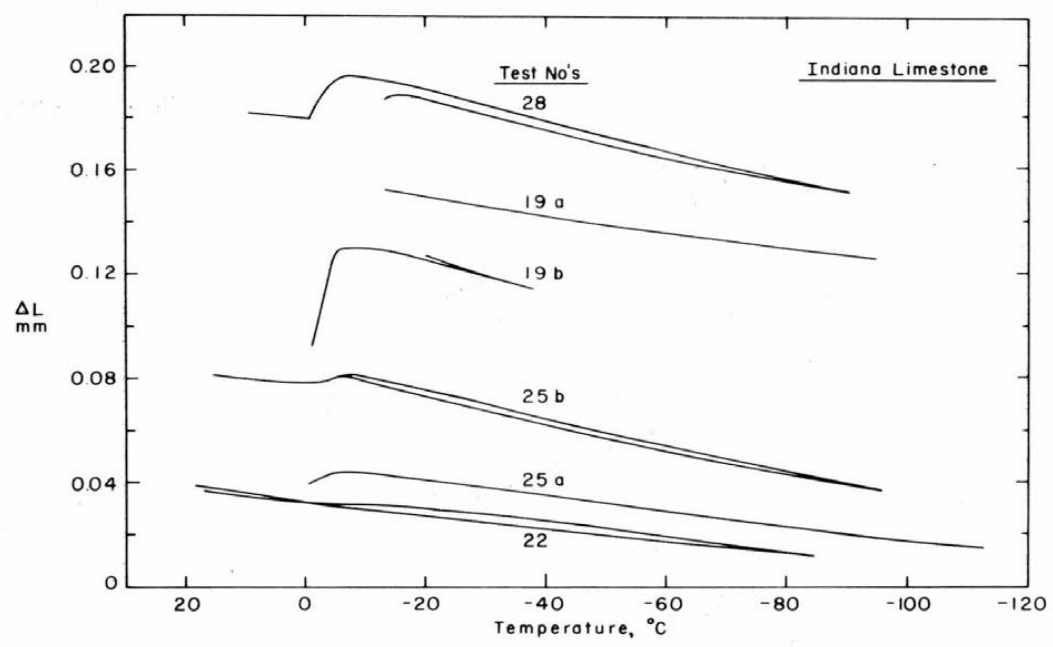

Figure 40. Thermal strain records for Indiana limestone.

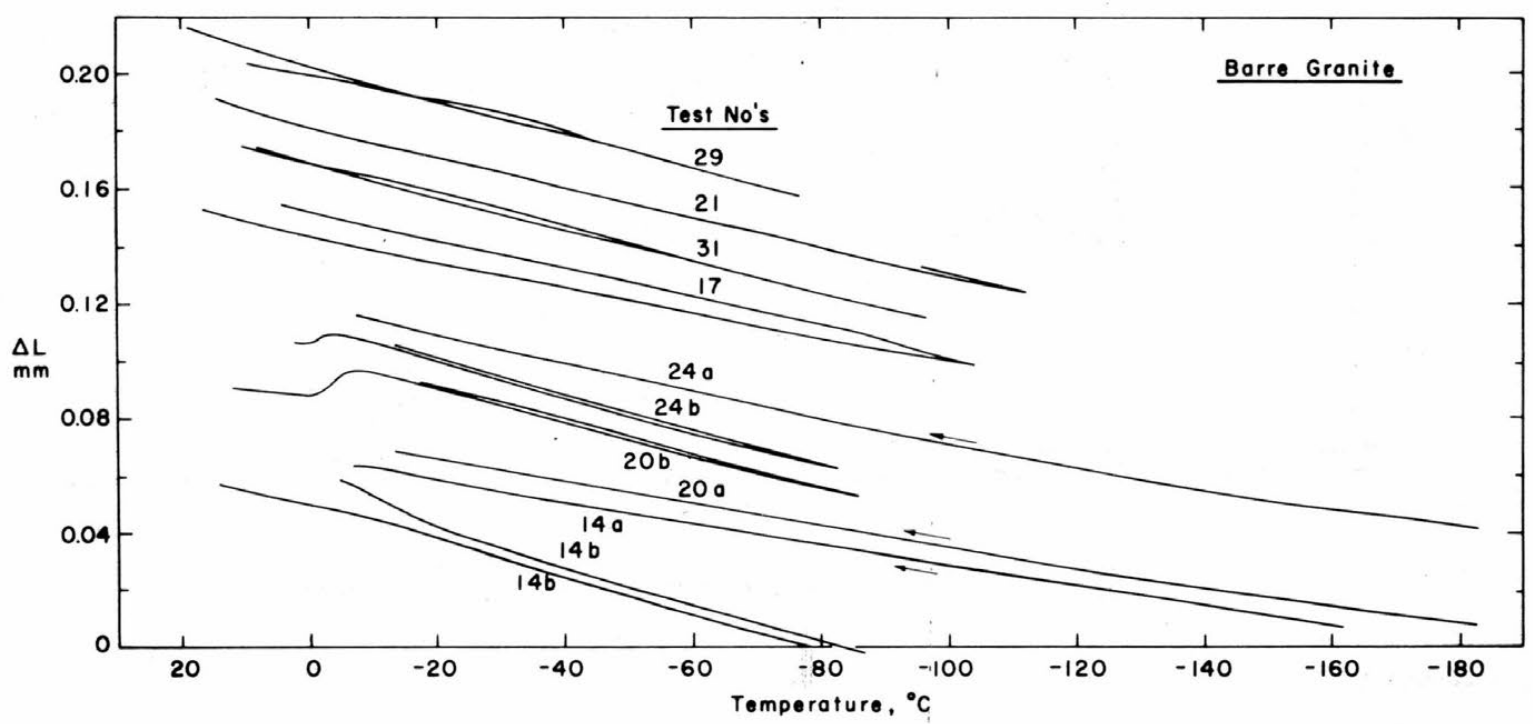

Figure 41. Thermal strain records for Barre granite.

depression for the rock. : The "strain reversal temperature," at which the effects of melting just balance the thermal expansion of the solid constituents, is approximately $-7^{\circ} \mathrm{C}$ for sandstone and limestone at high water contents, and approximately $-5^{\circ} \mathrm{C}$ for granite at high water contents.

The present results give only a rough idea of the absolute magnitude of the freezing strain. For wet Berea sandstone the freezing strain for quick-frozen rock is from about $1 \times 10^{-4}$ to $6 \times 10^{-4}$. The corresponding figures for Indiana limestone are about $0.9 \times 10^{-4}$ to $4 \times 10^{-4}$, and for Barre granite about $0.7 \times 10^{-4}$ to $1.3 \times 10^{-4}$. As might be expected, there appears to be an increase of freezing strain with increasing water content.

The other obvious feature of the results is the dependence of coefficient of expansion on the mode of freezing for wet rocks at low temperatures. In the range of temperatures from about $-15^{\circ}$ to $-90^{\circ} \mathrm{C}$, the coefficient of expansion for specimens which were "snap-frozen" in the dilatometer 
Table VI. Thermal strain data for cold rocks.

\begin{tabular}{|c|c|c|c|c|c|c|}
\hline Test & $\begin{array}{c}\text { Water } \\
\text { content } \\
\text { (g water/g rock) }\end{array}$ & $\begin{array}{l}\text { Specimen } \\
\text { length } \\
\text { at } 20^{\circ} \mathrm{C} \\
\text { (in.) }\end{array}$ & $\begin{array}{l}\text { Coefficient } \\
\text { of linear } \\
\text { expansion } \\
\left({ }^{\circ} \mathrm{C}^{-1}\right)\end{array}$ & $\begin{array}{c}\text { Temperature } \\
\text { range for } \\
\text { expansion } \\
\text { coefficient } \\
\left({ }^{\circ} \mathrm{C}\right)\end{array}$ & $\begin{array}{c}\text { Strain } \\
\text { reversal } \\
\text { temperature } \\
\left({ }^{\circ} \mathrm{C}\right)\end{array}$ & Remarks* \\
\hline \multicolumn{7}{|c|}{ Berea sandstone } \\
\hline 5 & $9 \times 10^{-2}(\mathrm{~s})$ & 4.055 & $11.3 \times 10^{-6}$ & -25 to -125 & -7.5 & $\mathrm{~A}(\mathrm{w})$ \\
\hline 6 & $5 \times 10^{-3}$ (a.d.) & 4.015 & & & & \\
\hline 11 & $9 \times 10^{-2}(\mathrm{~s})$ & 4.032 & & & & \\
\hline $13 \mathrm{a}$ & $9 \times 10^{-2}(\mathrm{~s})$ & 4.001 & $\begin{array}{l}11.4 \times 10^{-6} \\
9.56 \times 10^{-6} \\
7.26 \times 10^{-6}\end{array}$ & $\begin{array}{l}-20 \text { to }-75 \\
-75 \text { to }-120 \\
-120 \text { to }-170\end{array}$ & -4.5 & $\mathrm{~A}(\mathrm{w})$ \\
\hline $13 \mathrm{~b}$ & $9 \times 10^{-2}(\mathrm{~s})$ & 4.001 & $\begin{array}{l}12.6 \times 10^{-6} \\
11.2 \times 10^{-6}\end{array}$ & $\begin{array}{l}-15 \text { to }-55 \\
-55 \text { to }-85\end{array}$ & & $\mathrm{~B}(\mathrm{w}, \mathrm{c})$ \\
\hline 15 & $7.3 \times 10^{-3}$ & 4.011 & $\begin{array}{l}8.93 \times 10^{-6} \\
7.97 \times 10^{-6}\end{array}$ & $\begin{array}{l}+10 \text { to }-40 \\
-40 \text { to }-90\end{array}$ & & $A(w, c)$ \\
\hline $18 \mathrm{a}$ & $9 \times 10^{-2}(\mathrm{~s})$ & 4.003 & $\begin{array}{l}10.05 \times 10^{-6} \\
7.02 \times 10^{-6}\end{array}$ & $\begin{array}{l}-20 \text { to }-90 \\
-110 \text { to }-170\end{array}$ & & $A(w)$ \\
\hline $18 b$ & $9 \times 10^{-2}(\mathrm{~s})$ & 4.003 & $12.9 \times 10^{-6}$ & -15 to -47 & -6.25 & $\mathrm{~B}(\mathrm{w}, \mathrm{c})$ \\
\hline 23 & $1.22 \times 10^{-2}$ & 4.012 & $\begin{array}{l}10.2 \times 10^{-6} \\
8.21 \times 10^{-6}\end{array}$ & $\begin{array}{l}+7 \text { to }-30 \\
-40 \text { to }-93\end{array}$ & & $(w, c)$ \\
\hline $26 \mathrm{a}$ & $6.2 \times 10^{-2}$ & 4.014 & $\begin{array}{l}9.75 \times 10^{-6} \\
8.65 \times 10^{-6}\end{array}$ & $\begin{array}{l}-20 \text { to }-100 \\
-100 \text { to }-145\end{array}$ & -7.75 & $A(w)$ \\
\hline $26 \mathrm{~b}$ & $6.2 \times 10^{-2}$ & 4.014 & $11.15 \times 10^{-6}$ & -15 to -70 & -4.25 & $\mathrm{~B}(\mathrm{w}, \mathrm{c})$ \\
\hline 27 & $5.35 \times 10^{-2}$ & 4.015 & $\begin{array}{l}11.1 \times 10^{-6} \\
9.66 \times 10^{-6}\end{array}$ & $\begin{array}{l}-20 \text { to }-70 \\
-70 \text { to }-120\end{array}$ & -7 & $\mathrm{~B}(\mathrm{w}, \mathrm{c})$ \\
\hline 30 & $7.8 \times 10^{-2}$ & 4.019 & $\begin{array}{l}11.7 \times 10^{-6} \\
9.41 \times 10^{-6}\end{array}$ & $\begin{array}{l}-20 \text { to }-60 \\
-70 \text { to }-100\end{array}$ & -5 & $B(w, c)$ \\
\hline
\end{tabular}

\section{Indiana limestone}

\begin{tabular}{rlllllll}
7 & $2.4 \times 10^{-3}$ (a.d.) & 4.047 & & & \\
8 & $5.4 \times 10^{-2}$ (s) & & & & & \\
12 & $9.1 \times 10^{-3}$ & 4.032 & & & & \\
16 & $6.2 \times 10^{-3}$ & 4.046 & & & & \\
$19 \mathrm{a}$ & $5.4 \times 10^{-2}(\mathrm{~s})$ & 4.033 & $3.76 \times 10^{-6}$ & -20 to -40 & & $\mathrm{~A}(\mathrm{w})$ \\
$19 \mathrm{~b}$ & $5.4 \times 10^{-2}(\mathrm{~s})$ & 4.033 & $6.46 \times 10^{-6}$ & -20 to -40 & -7.75 & $\mathrm{~B}(\mathrm{w}, \mathrm{c})$ \\
22 & $9.1 \times 10^{-3}$ & 4.048 & $2.44 \times 10^{-6}$ & +15 to -85 & & $(\mathrm{w}, \mathrm{c})$ \\
$25 \mathrm{a}$ & $3.77 \times 10^{-2}$ & 4.049 & $2.90 \times 10^{-6}$ & -10 to -90 & -6.5 & $\mathrm{~A}(\mathrm{w})$ \\
$25 \mathrm{~b}$ & $3.77 \times 10^{-2}$ & 4.049 & $5.21 \times 10^{-6}$ & -10 to -70 & -6.5 & $\mathrm{~B}(\mathrm{w}, \mathrm{c})$ \\
& & & $4.18 \times 10^{-6}$ & -70 to -95 & & \\
28 & $4.69 \times 10^{-2}$ & 4.048 & $5.79 \times 10^{-6}$ & -20 to -60 & -7.0 & $\mathrm{~B}(\mathrm{w}, \mathrm{c})$ \\
& & & $4.67 \times 10^{-6}$ & -60 to -90 & & \\
\hline
\end{tabular}

* Symbols:
A - specimen pre-frozen slowly
(c) cooling run
B - specimen snap-frozen in dilatometer
(s) - effectively saturated
(w) - warming run
(a.d.) - air-dry 
Table VI (Cont'd). Thermal strain data for cold rocks.

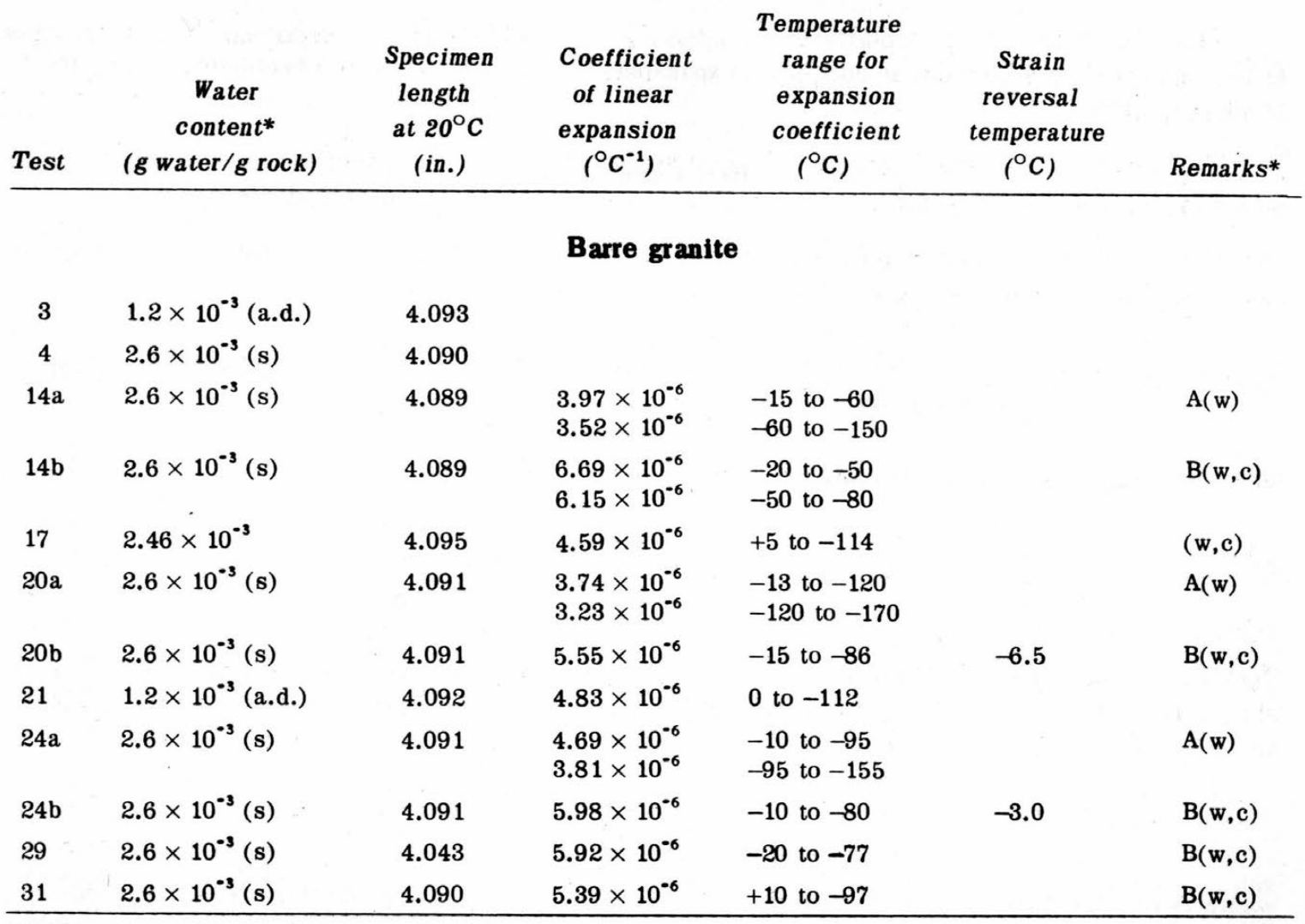

*Symbols:

A - specimen pre-frozen slowly

(c) - cooling run

B - specimen snap-frozen in dilatometer

(w) - warming run

(s) - effectively saturated

(a.d.) - air-dry

is significantly higher than the coefficient for specimens that were slowly prefrozen, with some opportunity for extrusion or redistribution of pore water. : The difference for Berea sandstone is about $10 \%$ to $30 \%$, for Indiana limestone about $70 \%$, and for Barre granite about $30 \%$ to $70 \%$. '

The strain-temperature traces are nonlinear over a sufficiently wide range of temperature, with slope, or expansion coefficients, decreasing as temperature decreases.

\section{Discussion}

Comparing the dilatometer results with results of differential thermal analysis and electrical conductivity tests, there can be no reasonable doubt that the discontinuity in thermal strain is caused mainly by phase change in the pore water of the rock.

Similar freezing strains have been observed in water-saturated porous glass by Antoniou (1964), and in porous glass with lower water contents by Hodgson and McIntosh (1960). ' In saturated porous glass the strain reversal temperature for thawing of adsorbed water was $-12^{\circ}$ to $-16^{\circ} \mathrm{C}$, and the strain discontinuity for freezing occurred at a lower temperature than that for thawing. There was, however, a strain discontinuity between $0^{\circ}$ and $-10^{\circ} \mathrm{C}$ that was not associated with heat effects. The porous 
glass used in Antoniou's experiments had saturation water content of 0.21 to $0.24 \mathrm{~g}$ water $/ \mathrm{g}$ rock and B.E.T. surface area of 82.5 to $94.5 \mathrm{~m}^{2} / \mathrm{g}$; the calculated pore diameter was about $6 \times 10^{-6} \mathrm{~mm}$, and all the water was adsorbed.

The dilatometer results obtained so far have given no indication of secondary phase changes at low temperature which might correspond with those observed in frozen clay at about $-40^{\circ} \mathrm{C}$ (Anderson, 1967).

The observed freezing strains are a good deal smaller than the theoretical maximum freezing strains for a water-saturated closed system, which can be calculated as follows.

For complete freezing of pore water in a saturated closed system of porosity $\boldsymbol{n}$ and zero elastic modulus, the potential volumetric freezing strain $\epsilon_{\mathrm{PV}}$ is:

$$
\epsilon_{\mathrm{PV}}=\frac{\text { vol ice }- \text { vol water }}{\text { specimen vol }}=0.09 n
$$

and, assuming isotropy, the potential linear freezing strain $\epsilon_{\mathrm{PL}}$ is:

$$
\epsilon_{\mathrm{PL}}=\frac{0.09 n}{3}=0.03 n
$$

(Specific volume of ice is taken as $1.09 \mathrm{~m}^{3} / \mathrm{Mg}$.) However, as the rock is elastic there will be some elastic restraint which reduces the potential freezing strain. The net volumetric strain $\epsilon_{\mathrm{N} V}$ will be:

$$
\epsilon_{\mathrm{NV}}=\epsilon_{\mathrm{PV}}-n \epsilon_{\mathrm{EI}}
$$

where $\epsilon_{\mathrm{EI}}$ is the elastic volumetric strain of the ice. Assuming that the ice exerts an effective pore pressure $\sigma$ on the rock, the pressure on the ice equals the tensile bulk stress in the rock matrix:

$$
\epsilon_{\mathrm{EI}}=\frac{\sigma}{K_{\mathrm{I}}}=\frac{K_{\mathrm{R}}}{K_{\mathrm{I}}} \epsilon_{\mathrm{NV}}
$$

where $K_{\mathrm{I}}$ is bulk modulus of ice in compression and $K_{\mathrm{R}}$ is bulk modulus of the rock in tension. Thus:

$$
\epsilon_{\mathrm{NV}}=\frac{\epsilon_{\mathrm{PV}}}{1+n\left(K_{\mathrm{I}} / K_{\mathrm{R}}\right)}
$$

and the net linear freezing strain $\epsilon_{\mathrm{NL}}$ is:

$$
{ }^{\epsilon} \mathrm{NL}=\frac{{ }^{\epsilon} \mathrm{PL}}{1+n\left(K_{\mathrm{I}} / K_{\mathrm{R}}\right)} .
$$

Taking the compressive Young's modulus of ice as $1.27 \times 10^{6} \mathrm{lbf} / \mathrm{in}^{2}{ }^{2}$ (see Hawkes and Mellor, in press) and Poisson's ratio for ice $\approx 0.4$ (Gold, 1968), then $K_{\mathrm{I}}=2.12 \times 10^{6} \mathrm{lbf} / \mathrm{in}^{2}{ }^{2}$. For Berea sandstone, Indiana limestone, and Barre granite, values of Young's modulus in tension for 
appropriate ranges of strain are, respectively, $0.278 \times 10^{6}, 3.07 \times 10^{6}$, and $4.56 \times 10^{6} \mathrm{lbf} / \mathrm{in} .^{2}$ (Gariepy, Hawkes and Mellor, unpublished). Corresponding values of Poisson's ratio from the same source are, respectively, $0.12,0.28$, and 0.34 . The resulting values of $K_{\mathrm{R}}$ for Berea sandstone, Indiana limestone, and Barre granite are, respectively, $1.22 \times 10^{5}, 2.33 \times 10^{6}$, and $4.75 \times 10^{6}$ $\mathrm{lbf} /$ in. $^{2}$ Substituting these values in eq 14 and 15 , it turns out that elastic restraint has little direct influence on freezing strain (Table VII).

Table VII. Linear freezing strains.

\begin{tabular}{|c|c|c|c|c|}
\hline \multirow[b]{2}{*}{ Rock type } & \multirow{2}{*}{$\begin{array}{c}\text { Observed } \\
\text { freezing } \\
\text { strain } \\
\times 10^{-4}\end{array}$} & \multicolumn{2}{|c|}{$\begin{array}{l}\text { Theoretical } \\
\text { freezing strains }\end{array}$} & \multirow{2}{*}{$\begin{array}{l}\text { Tensile failure } \\
\text { strain for wet } \\
\text { rock (from } \\
\text { uniaxial tensile } \\
\text { tests) } \\
\times 10^{-4}\end{array}$} \\
\hline & & $\begin{array}{l}\epsilon_{\mathrm{PL}} \\
\times 10^{-4}\end{array}$ & $\begin{array}{l}{ }^{{ } \mathrm{NL}} \\
\times 10^{-4}\end{array}$ & \\
\hline Berea sandstone & 1 to 6 & 54.7 & 54.1 & 8.1 \\
\hline Indiana limestone & 0.9 to 4 & 39.0 & 33.8 & 3.5 \\
\hline Barre granite & 0.7 to 1.3 & 1.91 & 1.88 & 5.4 \\
\hline
\end{tabular}

The potential volumetric freezing strain for an unsaturated rock, $\epsilon_{\mathrm{PV}}^{\prime}$, will be less than $\epsilon_{\mathrm{PV}}$ if the pore water can distribute itself through the pore system as freezing takes place. Assuming that pore space can be fully utilized:

$$
\epsilon_{\mathrm{PV}}^{\prime}=\frac{\text { vol ice }- \text { vol pores }}{\text { specimen vol }}=1.09 W \gamma_{\mathrm{R}}-n
$$

where $W$ is water content (mass of water per unit mass of rock) and $\gamma_{R}$ is dry bulk density of the rock in $\mathrm{g} / \mathrm{cm}^{3}$ or $\mathrm{Mg} / \mathrm{m}^{3}$. Ignoring the rather small effect of elastic restraint, the potential linear freezing strain for an unsaturated specimen $\epsilon_{\mathrm{PL}}^{\prime}$ is:

$$
\epsilon_{\mathrm{PL}}^{\prime}=\frac{1}{3}\left(1.09 W \gamma_{\mathrm{R}}-n\right) \text {. }
$$

With this simple interpretation the freezing strain would reduce to zero at a water content $W_{*}$, where:

$$
W_{*}=\frac{n}{1.09 \gamma_{\mathrm{R}}} \cdot
$$

Values of $W_{*}$ for Berea sandstone, Indiana limestone, and Barre granite are, respectively, $8.54 \times$ $10^{-2}, 5.65 \times 10^{-2}$, and $2.41 \times 10^{-3} \mathrm{~g}$ water $/ \mathrm{g}$ rock. This effect of unsaturation is clearly a powerful one in reducing freezing strain, but the calculated values of $W_{*}$ are higher than some of the water contents at which substantial freezing strains were observed. Thus it seems that the pore space cannot be fully utilized, even when freezing occurs slowly.

The failure strains for these rocks in uniaxial tension are known from other studies (Gariepy, Hawkes and Mellor, unpublished), and they are given in Table VII. It can be seen that the observed freezing strains come close to the strains for complete tensile failure of the rocks, while the 


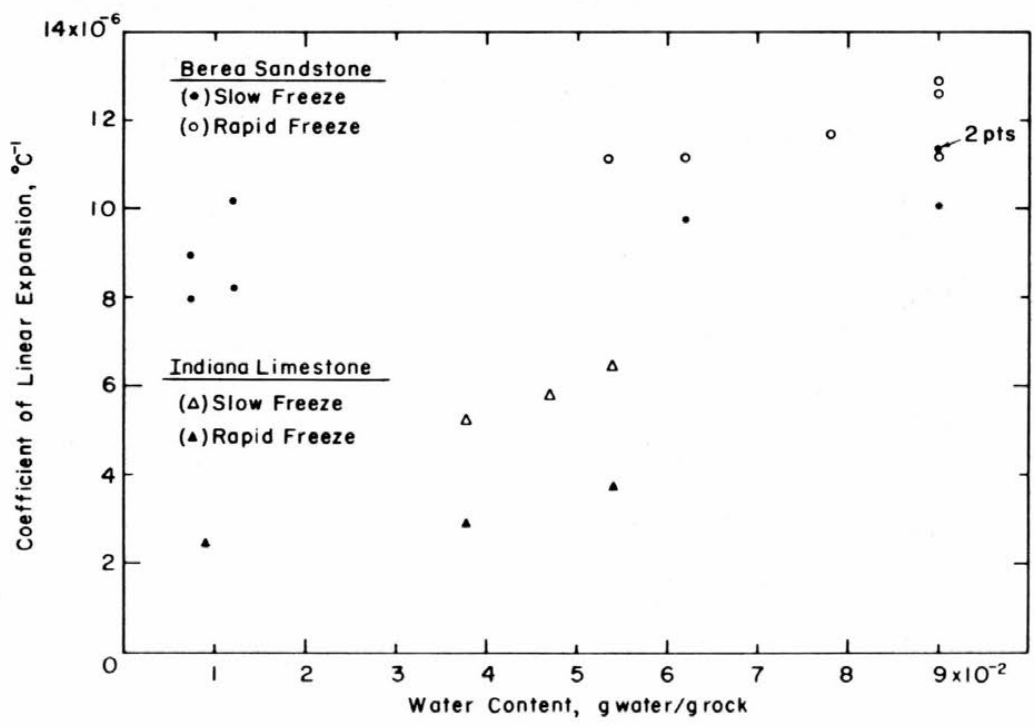

Figure 42. Coefficient of linear expansion (approximately $-15^{\circ}$ to $-90^{\circ} \mathrm{C}$ ) plotted against water content for Berea sandstone and Indiana limestone.

potential freezing strains for completely saturated rock frozen rapidly far exceed the tensile failure strain for sandstone and limestone. It should also be noted that internal cracking of these rocks almost certainly occurs at tensile strains well below the ultimate tensile failure strain.

In Figure 42 expansion coefficient measured within the temperature range $-15^{\circ}$ to $-90^{\circ} \mathrm{C}$ is plotted against water content for Berea sand stone and Indiana limestone. While these data are rather sketchy, they do show certain trends: coefficient of expansion increases with increasing water content, and for any given water content it tends to be higher when the rock has been frozen rapidly. These effects are tentatively attributed to partial relaxation of freezing strain, since the coefficient of expansion for ice, about $50 \times 10^{-6}{ }^{\circ} \mathrm{C}^{-1}$ (Butkovich, 1957), is much higher than the coefficient of expansion for dry rock.

\section{Conclusions}

The dilatometer used for this work is basically a satisfactory instrument, although an improved temperature control is required. Improved equipment would permit more quantitative dat a analysis.

The rocks tested showed significant freezing strains when water content was above $50 \%$ of the saturation value. Freezing strain increased with increasing water content and was highest for rapid rates of freezing. Observed freezing strains for specimens with high water contents were lower than theoretical freezing strains for saturated closed systems, but tended to be higher than freezing strains calculated on the assumption that pore space in an unsaturated specimen could be fully utilized.

Observed freezing strains approached the tensile failure strain, and they were of a magnitude which might be associated with onset of internal cracking.

\section{E. ISOTHERMAL COMPRESSIBILITY OF COLD ROCKS}

The phase diagram for ice (Fig. 43) shows that pressure-induced phase transformations can occur when ice is compressed at constant temperature. If the pores of a rock are filled with ice, then it is likely that the compressibility curve for that rock will exhibit steplike discontinuities 


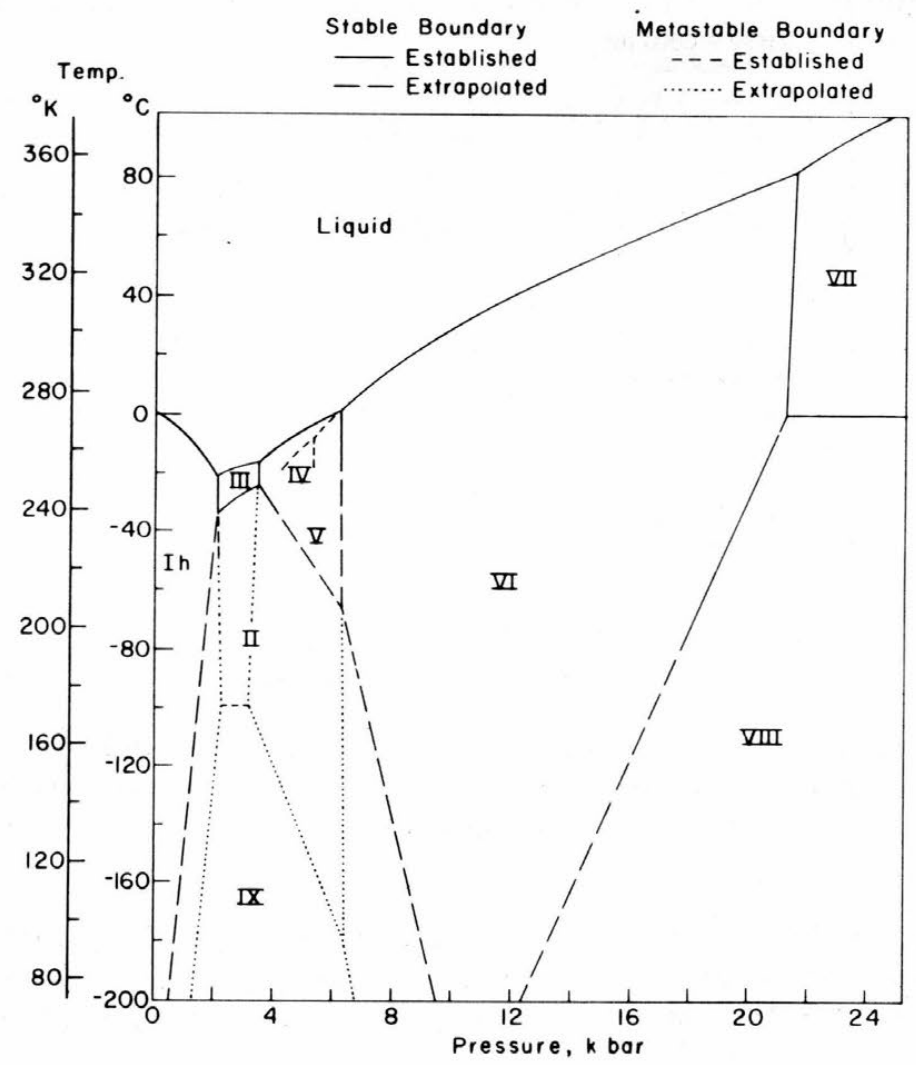

Figure 43. Phase diagram for ice in the pressure-temperature plane. (After Whalley, 1969.)

when the frozen pore water is transformed from one type of ice to another type of different density. To check this point experimentally, isothermal hydrostatic compression tests were run on specimens of rock at a temperature of $-10^{\circ} \mathrm{C}$. Measurements were made in collaboration with Dr. Pieter Hoekstra of USA CRREL, who was engaged in a program of compressibility measurements for soils.

\section{Test method}

The test equipment (Fig. 44) consisted of a high pressure die, of the Bridgman type, with $1 / 2$-in.diameter tungsten carbide pistons driven by a 300,000-lbf Tinius-Olsen universal testing machine. It was basically almost identical to equipment described by Stephens (1964), but had temperature control modifications. The actual apparatus is described by Chamberlain and Hoekstra (1969).

Rock specimens for these tests were necessarily small: diameter was $0.450 \pm 0.003 \mathrm{in}$. and length was $0.500 \pm 0.001 \mathrm{in}$. The specimens were prepared by taking a nominal $1 / 2$-in.-diameter core from block material, dressing it to finished diameter on a lathe with a toolpost grinder, and trimming the ends on a surface grinder. Dimensioned specimens were dried and conditioned (see Mellor, in press), and were finally inserted into 0.500 -in.-OD lead capsules at a temperature of $-10^{\circ} \mathrm{C}$. The open end of each capsule was closed by slicing and folding in the excess length, and it was sealed by pressure in the testing die.

Pressure was applied to the pistons at a low rate (about $40 \mathrm{~min}$ for a cycle), but while this rate was sufficiently low for dissipation of heat, it may not have allowed enough time for complete phase changes. Piston force was measured by an electrical load cell (Stromberg), and piston displacement 


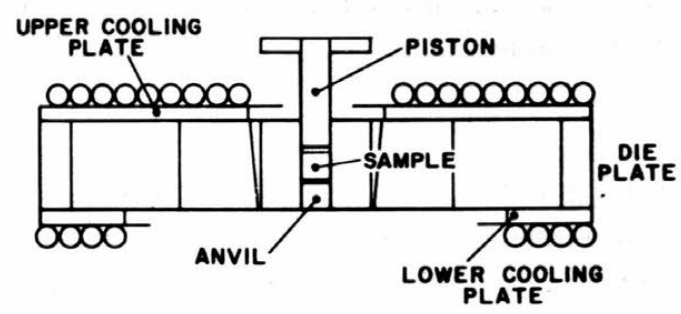

HIGH PRESSURE DIE

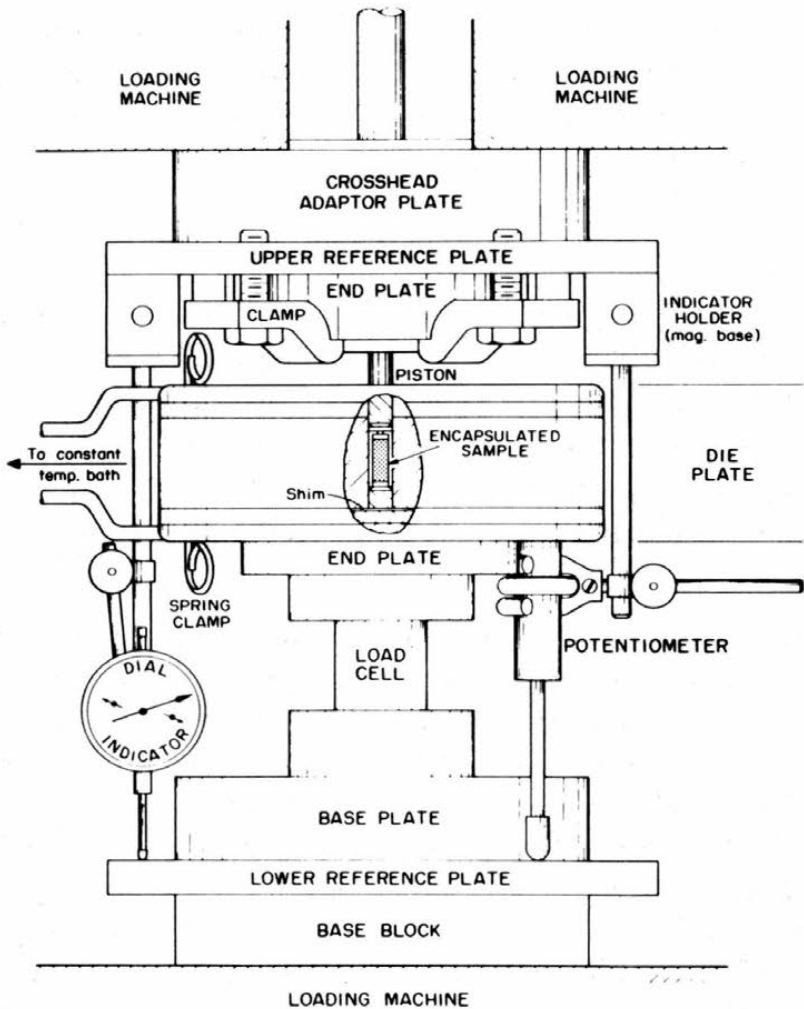

Figure 44. High pressure die and loading machine.

was measured by a linear potentiometer (Computer Instruments Corp.). Outputs from the load cell and the potentiometer were fed to an $X-Y$ recorder (Moseley) to give a continuous trace of load versus displacement. The loading apparatus was housed in a room regulated to a temperature of $-10^{\circ} \mathrm{C}$, and the temperature of the die was controlled precisely at $-10^{\circ} \mathrm{C}$ by circulating glycol from a constant temperature bath. Die temperature was measured by a glass bead thermistor and a Wheatstone bridge.

Calibration runs were alternated between test runs, so that each test run was sandwiched between a pair of calibration runs. For a calibration run a specimen of gold was tested. The compressibility of gold is low and accurately known, and therefore the measured piston displacements could easily be corrected for effects of straining in the die and pistons.

Friction effects were adjusted out by making corrections from a closed hysteresis loop of pressure versus piston displacement for loading and unloading. The correction was taken as one half 
the pressure difference between loading and unloading after the specimen had been cycled enough times to produce a closed hysteresis loop.

\section{Test results}

The first set of data was obtained for Berea sandstone in dry and water-saturated conditions. The testing equipment was controlled by an experienced operator, the work was directly supervised, and the results appear to be good (Fig. 45, 46). ' Tests were also run on Indiana limestone and Barre granite, in both dry and saturated conditions. These latter tests were made on a "space available" basis without direct supervision, and the equipment was controlled by a new operator of limited experience. The results are shown in Figures 47 and 48, but they are not felt to be very reliable, particularly in the case of the specimens which were supposed to be saturated. Although these latter specimens were prepared and frozen in a saturated condition, the results suggest that some of the pore water may have been lost subsequently. : Figures 47 and 48 are given for purposes of record, but the results will not be discussed further.

\section{Discussion of results}

Figure 45a gives results for the first and seeond runs on dry Berea sandstone. The curve for the first run affords an opportunity to check on the use of compressibility as a means of measuring porosity. : Taking the intercept given by the tangent to the linear high pressure portion of the curve, a value $V / V_{0}=V_{\mathrm{s}} / V_{0}=0.796$ is obtained, where $V_{\mathrm{s}}$ is the volume of solid material and $V_{0}$ is initial bulk volume. This gives a porosity of 0.204 , or $20.4 \%$, which agrees quite well with the value $19.8 \%$ obtained by water saturation and the value 20.6 obtained in the air comparison pycnometer.

Figure $45 \mathrm{~b}$ gives results for the 4 th compression of saturated Berea sandstone, any unfilled pores having been closed by preceding runs. From Figure $45 \mathrm{~b}$, and from Figure 46 in which the same data are plotted in the form of $-\Delta V / V_{0}$ against pressure, it is immediately evident that the compressibility characteristic has discontinuities. The first step increase of volumetric strain occurs at approximately $1 \mathrm{~kb}$; this can be identified with the transition from Ice-I to water, which ought to take place at $1.11 \mathrm{~kb}$ at $-10^{\circ} \mathrm{C}$ (Table VIII). ' Since the ice represents about $20 \%$ of the total volume of the unloaded sandstone, the step volumetric strain of $2.5 \times 10^{-2}$ is of the expected magnitude for the Ice-I to water transition $\left(10.2 \times 10^{-2}-\right.$ see Table VIII). The second step increase of volumetric strain initiated at about $5.15 \mathrm{~kb}$; this pressure is higher than the stable phase boundary for the transition from water to Ice IV/V, but it corresponds closely to the metastable boundary (approximately $5.2 \mathrm{~kb}$ ) shown by a broken line in Figure 43 . The second step reaches completion at about $5.5 \mathrm{~kb}$, and there is a third small step at $6.5 \mathrm{~kb}$, which can probably be identified with the transition from Ice $\mathrm{V}$ to Ice VI at $6.25 \mathrm{~kb}$ (Table VIII). The total volume change for the second and third steps corresponds closely to $20 \%$ of the total volume change for compression from water at $4.42 \mathrm{~kb}$ to Ice VI at $6.25 \mathrm{~kb}$. The transition from Ice VI to Ice VIII at $20.8 \mathrm{~kb}$ is not reflected by a distinct step in the compression curve for Berea sandstone, although the curve does show increased compressibility above $22 \mathrm{~kb}$.

These results are encouraging, although it would be desirable to have more data, with tests run more slowly in order to allow ample time for phase changes to occur at the appropriate pressure. Present indications are that the compressibility and phase transformation effects of frozen pore water can be accounted for from the phase diagram for water. : It has been shown that compressibilities for rocks can be predicted with adequate accuracy from known compressibilities of the constituent minerals, using Voigt-Reuss-Hill averaging methods (Brace, 1965). Chamberlain and Hoekstra (1969) have shown that similar methods can be applied to predict the compressibilities of soils, and they have succeeded in accounting for the influence of frozen pore water, in both completely and incompletely saturated soils, by drawing on data from the phase diagram for water. 


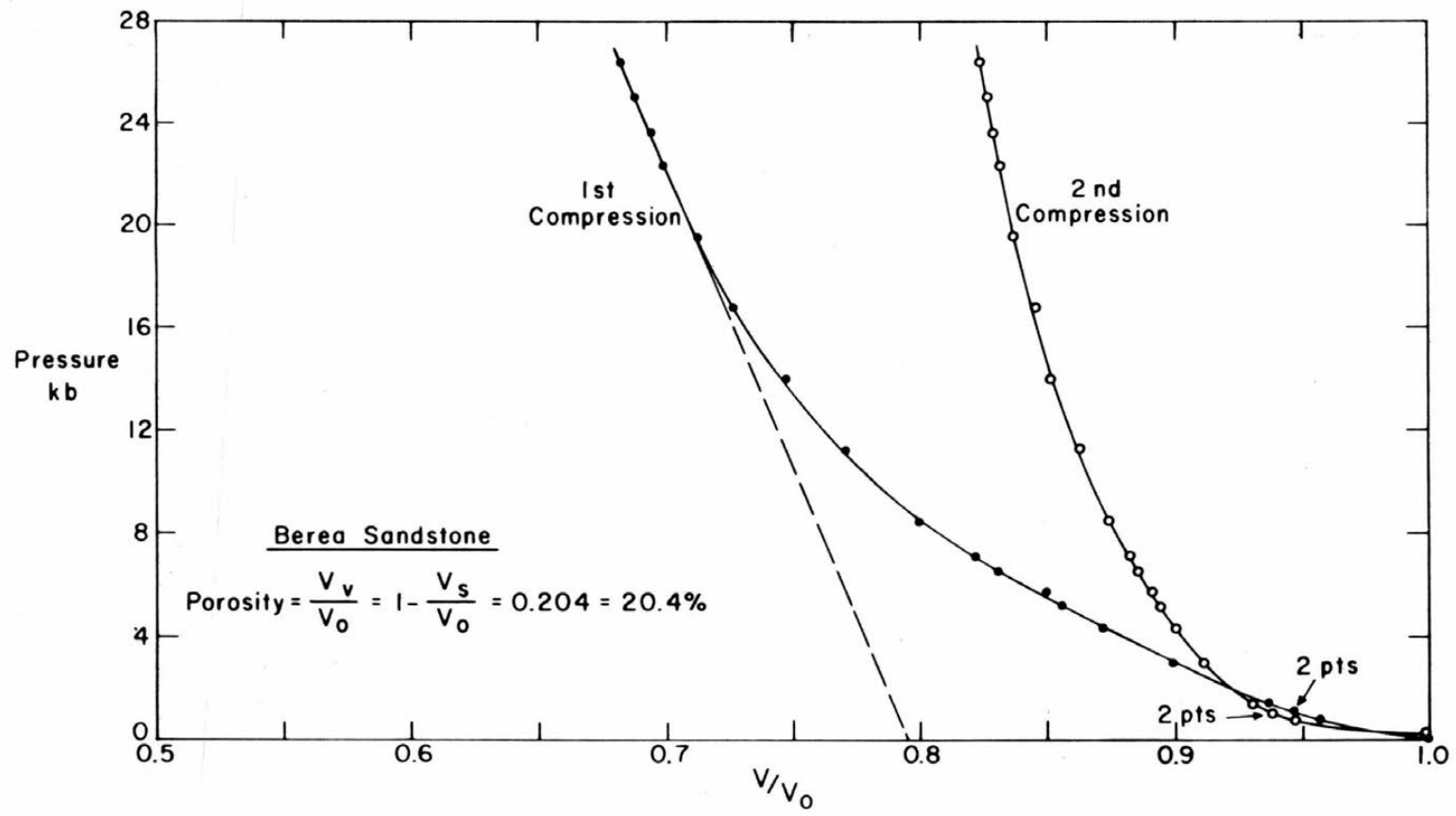

a. Nominally Dry

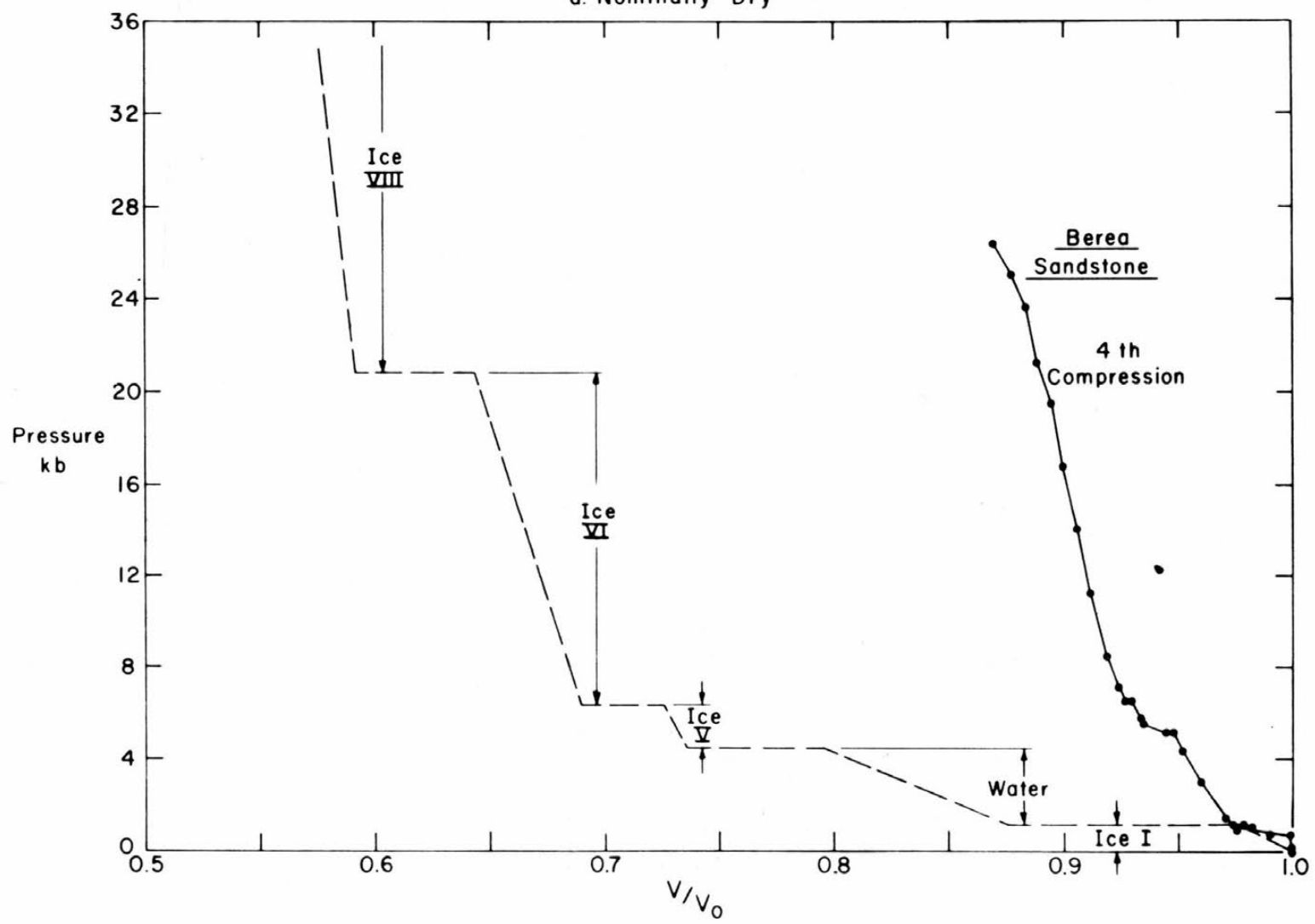

b. Nominally Saturated

Figure 45. Pressure-volume relationships for hydrostatic compression of dry sandstone and watersaturated sandstone at $-10^{\circ} \mathrm{C}$. 

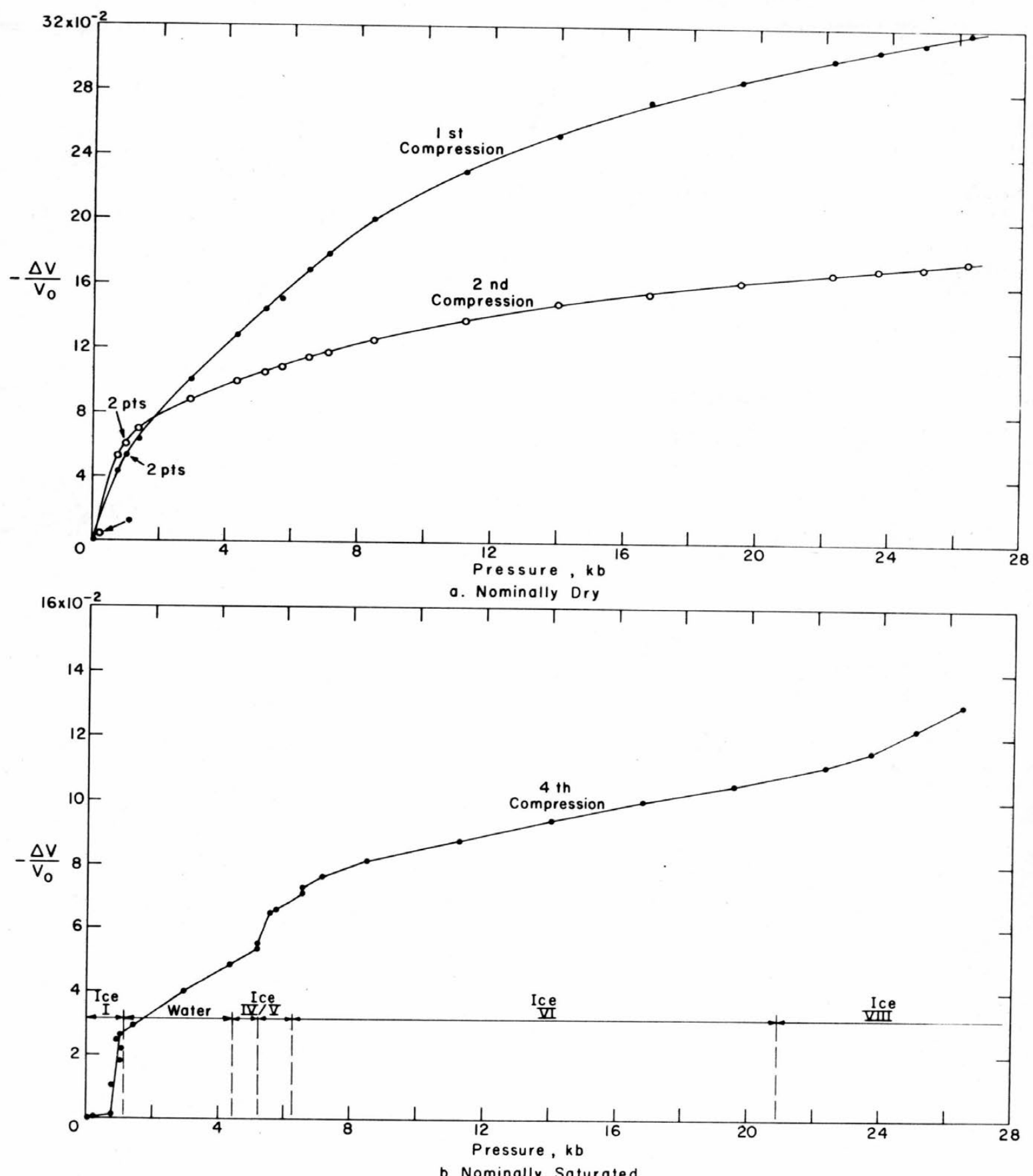

Figure 46. Volumetric strain as a function of hydrostatic pressure at $-10^{\circ} \mathrm{C}$ for dry sandstone and water-saturated sandstone. 


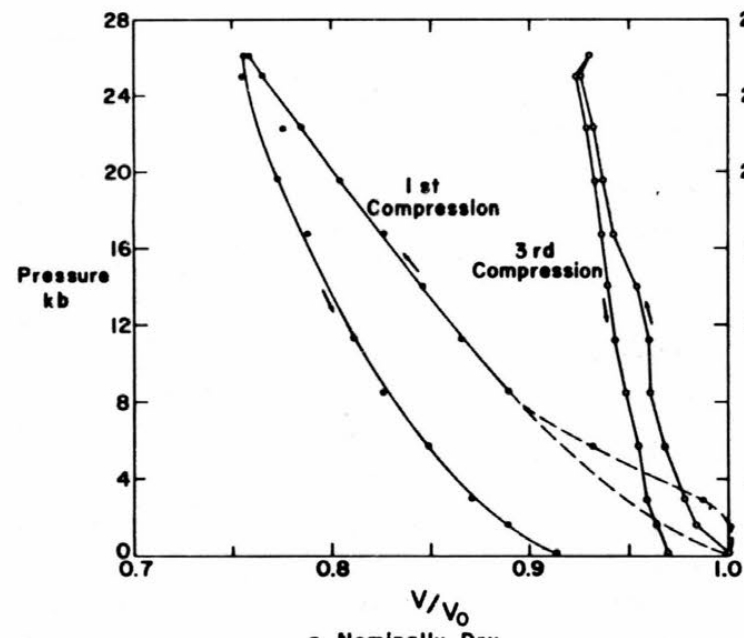

a. Nominally Dry

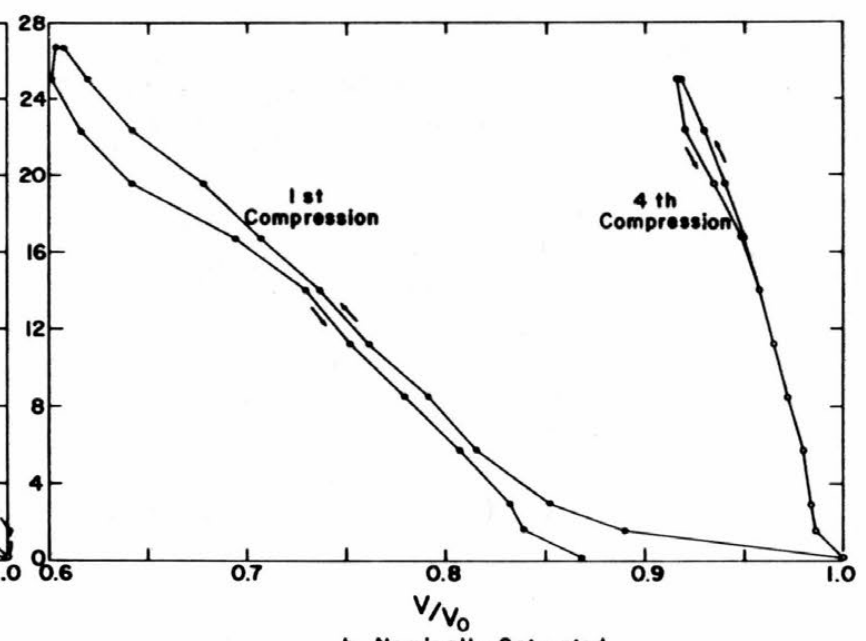

b. Nominally Saturated

Figure 47. Pressure-volume relationships for hydrostatic compression of nominally dry and nominally saturated specimens of Indiana limestone at $-10^{\circ} \mathrm{C}$.

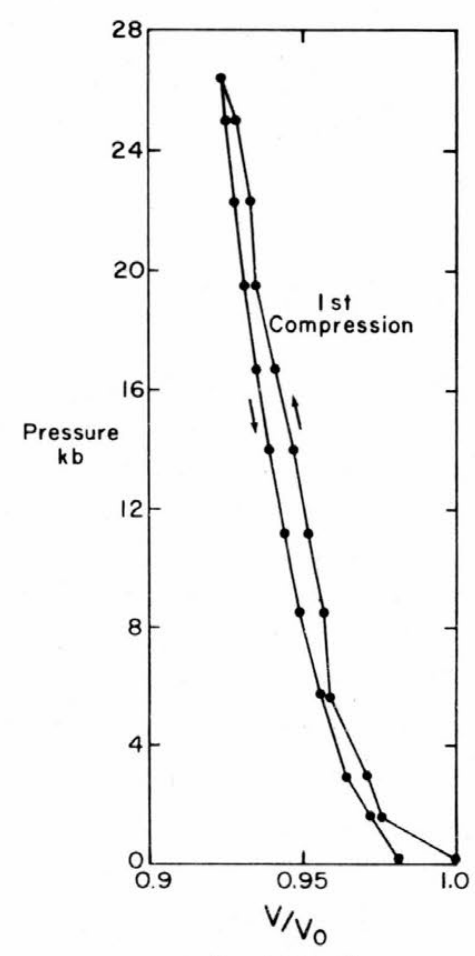

a. Nominally Dry

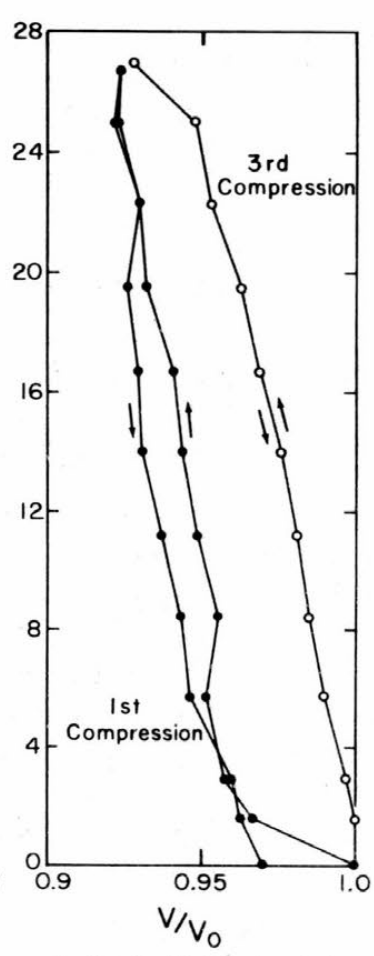

b. Nominally Saturated

Figure 48. Pressure-volume relationships for hydrostatic compression of nominally dry and nominally saturated specimens of Barre granite at $-10^{\circ} \mathrm{C}$. 
Table VIII. Compressibility of ice at $-10^{\circ} \mathrm{C}$.

(Calculated from Bridgman's data by Chamberlain and Hoekstra, 1969.)

\begin{tabular}{lccc} 
Phase & $\begin{array}{c}\text { Pressure } \\
(\mathrm{kb})\end{array}$ & $\begin{array}{c}\text { Specific } \\
\text { volume } \\
\left(\mathrm{cm}^{3} / \mathrm{g}\right)\end{array}$ & $\begin{array}{c}\text { Relative } \\
\text { volume } \\
\left(\mathrm{V} / \mathrm{V}_{0}\right)\end{array}$ \\
\hline Ice I & 0.0 & 1.0900 & 1.000 \\
Ice I & 1.11 & 1.0664 & 0.978 \\
Water & 1.11 & 0.9544 & 0.876 \\
Water & 4.42 & 0.8688 & 0.796 \\
Ice V & 4.42 & 0.8012 & 0.736 \\
Ice V & 6.25 & 0.7907 & 0.726 \\
Ice VI & 6.25 & 0.7522 & 0.690 \\
Ice VI & 20.8 & 0.702 & 0.644 \\
Ice VIII & 20.8 & 0.645 & 0.592 \\
Ice VIII & 49.1 & 0.60 & 0.55 \\
\hline
\end{tabular}

\section{Conclusions and recommendations}

From the limited data given here, and from the results of related studies which have just been outlined, there seems good reason to believe that the compressibility characteristics of icebearing rocks can be predicted if the compressibility characteristics and modal distributions of the constituents are known. : Nevertheless, it seems desirable to gather additional experimental evidence, of higher quality and for a range of rock types, before the question is considered closed. :

\section{GENERAL SUMMARY OF RESULTS}

In typical porous rock, freezing point depression ranges from a fraction of a degree at water contents near saturation to indefinitely high values $\left(>10^{\circ} \mathrm{C}\right)$ at the maximum adsorbed water content of the rock. : This implies that pore water freezes progressively as temperature falls, leaving a residual quantity of unfrozen water. : The small amount of water which remains unfrozen below $-10^{\circ} \mathrm{C}$ is electrically continuous, which suggests that it is also hydraulically continuous, and perhaps mobile under potential gradients (mechanical, thermal, electrical). : Changes in electrical conductivity with temperature suggest that the thickness, continuity and mobility of the unfrozen interfacial water film decrease with decreasing temperature down to a temperature of approximately $-125^{\circ} \mathrm{C}$. : Discontinuities in the relation ship between electrical conductivity and temperature indicate rather abrupt changes in the properties of the interfacial layer at certain temperatures.

The pore water freezing characteristics of rocks can be determined by differential thermal analysis, but the required measurements are time-consuming, and the method is inherently unsuitable for measurements on rocks of very low porosity. : It appears that a good estimate of the limiting unfrozen water content for typical environmental low temperatures can be obtained from a simple room temperature measurement of adsorbed water content. It also appears possible to estimate the pore water freezing characteristics indirectly from relatively simple mercury penetration measurements. :

When pore water freezes, the resulting $9 \%$ increase in specific volume can produce significant volumetric strains in the rock. : Bulk freezing strain increases with increasing water content and increasing freezing rate; at high water contents $(>50 \%$ saturation) freezing strain may be sufficient 
to cause internal cracking of the rock. A sensitive recording dilatometer with good temperature control provides a sensitive means of studying pore water phase changes.

When ice-bearing rock is subjected to sufficiently high hydrostatic pressure at constant temperature, ice in the pores undergoes phase transformations, changing from Ice-I to successively denser modifications as pressure is increased. : The isothermal compressibility characteristics of ice bearing rocks can probably be calculated to an acceptable degree of accuracy if the compressibility characteristics and modal distributions of the constituents, including ice, are known.

In view of the demonstrated existence of unfrozen mobile water in cold rocks, reappraisal of frost-damage processes in rocks and synthetic porous materials seems indicated. : A logical progression in such an investigation would involve study of water migration under potential gradients and water/ice segregation in preferred locations.

\section{LITERATURE CITED}

Adamson, A.W. (1960) Physical chemistry of surfaces. Interscience Publishers, 629 p.

Anderson, D.M. (1967) Ice nucleation and the substrate-ice interface. Nature, vol. 216, p. 563-566.

(1967) The interface between ice and silicate surfaces. Journal of Colloid and Interface Science, vol. 25, no. 2, p. 174-191.

(1968) Undercooling, freezing point depression, and ice nucleation of soil water. Israel Journal of Chemistry, vol. 6, p. 349-355.

Antoniou, A.A. (1964) Phase transformations of water in porous glass. Journal of Physical Chemistry, vol. 68, p. 2754-2764.

Berg, R. and Maffei, T.A. (1968) Thermal strain in rock cores from Mineville, New York. U.S. Army Cold Regions Research and Engineering Laboratory (USA CRREL) Technical Note (unpublished).

Brace, W.F. (1965) Some new measurements of linear compressibility of rocks. Journal of Geophysical Research, vol. 70, no. 2, p. 391-398.

Bunton, G.V. and Weintroub, S. (1968) A sensitive optical lever dilatometer for use at low temperatures and the thermal expansion of copper. Cryogenics, Dec, p. 354-360.

Butkovich, T.R. (1957) Linear thermal expansion of ice. U.S. Army Snow, Ice and Permafrost Research Establishment (USA SIPRE) Research Report 40.

Chamberlain, E. and Hoekstra, P. (1969) The isothermal compressibility of frozen soil and ice to 30 kilobars at $-10^{\circ} \mathrm{C}$. USA CRREL Technical Report 225.

Dorsey, N.E. (1940) Properties of ordinary water substance. New York: Reinhold.

Dumas, M.C. (1962) Electrical resistivity and dielectric constant of frozen rocks. Colorado School of Mines, M. Sc. thesis.

Dunn, J.R. and Hudec, P.P. (1965a) Quantitative cold differential thermal analysis. Contribution 65-7, Department of Geology, Rensselaer Polytechnic Institute (New York State Department of Public Works, Physical Research Report).

(1965b) The influence of clays on water and ice in rock pores (Part II). Contribution 65-8, Department of Geology, Rensselaer Polytechnic Institute (New York State Department of Public Works, Physical Research Report 65-5).

Gold, L.W. (1968) Elastic and strength properties of fresh water ice. National Research Council of Canada, Associate Committee of Geotechnical Research, Technical Memorandum 92, p. 13-23. 
Hawkes, I. and Mellor, M. (In press) Deformation and fracture of ice under uniaxial stress. Journal of Glaciology.

Hodgson, C. and McIntosh, R. (1960) The freezing of water and benzine in porous Vicor glass. Canadian Journal of Chemistry, vol. 38, p. 958-971.

Hoekstra, P. and O`Brien, H.W. (1969) The dielectric properties of clay suspensions in the frequency range from $50 \mathrm{~Hz}$ to $20 \mathrm{kHz}$. USA CRREL Research Report 266.

Hoekstra, P. and Doyle, W.T. (1969) Microwave dielectric absorption of surface adsorbed water. Autumn meeting, National Academy of Sciences, Hanover, N.H.

Jellinek, H.H.G. and Fok, S.Y. (1967) Freezing of aqueous polyvinylpyrrolidone solutions. Kolloid-Zeitschrift und Zeitschrift fur Polymere, Band 220, Heft 2, p. 122-133.

Keller, G.V. (1966) Electrical properties of rocks and minerals. In Handbook of Physical Constants, Geological Society of America, Memoir 97, p. 553-577.

(1967) Supplementary guide to the literature on electrical properties of rocks and minerals. In E.I. Parkhomenko, Electrical Properties of Rocks. New York: Plenum Press, p. 265-308 (translated from Russian by G.V. Keller - originally published by Nauka Press, Moscow, for O.Yu. Schmidt Institute of Physics of the Earth of the Academy of Sciences of the USSR).

Keune, R: and Hoekstra, P. (1967) Calculating the amount of unfrozen water in frozen ground from moisture characteristic curves. USA CRREL Special Report 114.

Kumai, M. (1968) Hexagonal and cubic ice at low temperatures. Journal of Glaciology, vol. 7 , no. 49 , p. 95-108.

Lange, G.R. and McKim, H.L. (1963) Saturation, phase composition, and freezing point depression in a rigid soil model. Proceedings of the Permafrost International Conference, Lafayette, Indiana, NAS/NRC Publication 1287, p. 187-191.

Low, P.F.; Hoekstra, P. and Anderson, D.M. (1968) Some thermodynamic relationships for soils at or below the freezing point. Water Resources Research, vol. 4, no. 2, p. 379-394 and no. 3, p. 541,544. (Also USA CRREL Research Report 222, pt. 1, 1966 and pt. 2, 1967.)

Mellor, M. (In press) Strength and deformability of rocks at low temperatures. USA CRREL Research Report.

and Smith, J.H. (1966) Strength studies on snow. International Association of Scientific Hydrology, Symposium at Davos, Publication 69, p. 100-113.

Mellor, M. and Testa, R. (1969) Effect of temperature on the creep of ice. Journal of Glaciology vol. 8, No. 52.

Miller, A.A. (1969) Glass transition temperature of water. Science, vol. 163, p. 13251326.

Miller, R.D. (1963) Discussion of "Saturation, phase composition and freezing point depression in a rigid soil model" by Lange and McKim. Proceedings, Permafrost International Conference, Lafayette, Indiana, NAS/NRC Publication 1287, p. 191-192.

Parkhomenko, E.I. (1967) Electrical properties of rocks. New York: Plenum Press, 262 p. plus 43 p. supplement. (Translated from Russian by G.V. Keller. Published by Nauka Press, Moscow, for O.Yu. Schmidt Institute of Physics of the Earth of the Academy of Sciences of the USSR.)

Schofield, R.K. and Botelho de Costa, J.V. (1938) The measurement of pF in soil by freezing point. Journal of Agricultural Science, vol. 28, p. 644-653.

Scott, J.H.; Carroll, R.D. and Cunningham, D.R. (1967) Dielectric constant and electrical conductivity measurements of moist rock: A new laboratory method. Journal of Geophysical Research, vol. 72, no. 20, p. 5101-5115. 
Stephens, D.R. (1964) The hydrostatic compression of eight rocks. Journal of Geophysical Research, vol. 69, no. 14, p. 2967-2978.

Whalley, E. (1969) Structure problems of ice. In Physics of Ice. Proceedings of the International Symposium on Physics of Ice, Munich, 9-14 Sept 1968 (N. Riehl, B. Bullemer, H. Engelhardt, Ed.). New York: Plenum Press, p. 19-43.

Yannas, I. (1968) Vitrification temperature of water. Science, vol. 160, p. 298-299. 


\section{APPENDIX A: WATER ADSORPTION}

Water adsorption measurements were made on samples of the three rocks in anticipation of a correlation between adsorbed water and unfrozen water. : Disk-shaped samples, $2 \%$ in. in diameter by approximately $1 / 2$ in. thick, were oven dried for 3 days at $110^{\circ} \mathrm{C}$ and weighed while still hot. They were then placed on point supports, exposed to an atmosphere at $100 \%$ relative humidity for 4 days, and reweighed.

After the first adsorption measurement the test was repeated and it was found that more water was adsorbed on the second test. : As a result of this finding, it was decided that further repetitions of the test should be made. The results obtained are tabulated below, and are plotted in Figure A1.

Surface areas of the rocks were measured by the B.E.T. method using nitrogen adsorption:

$\begin{array}{ll}\text { Berea sandstone } & 1.25 \mathrm{~m}^{2} / \mathrm{g} \\ \text { Indiana limestone } & 0.654 \mathrm{~m}^{2} / \mathrm{g} \\ \text { Barre granite } & 0.105 \mathrm{~m}^{2} / \mathrm{g}\end{array}$

Thus the water per unit surface taken up by each rock when exposed to a humid environment is approximately:

$\begin{array}{lc}\text { Berea sandstone } & 4 \times 10^{-3} \mathrm{~g} \text { wat } \mathrm{er} / \mathrm{m}^{2} \\ \text { Indiana limestone } & 4 \times 10^{-3} \mathrm{~g} \text { water } / \mathrm{m}^{2} \\ \text { Barre granite } & 10 \times 10^{-3} \mathrm{~g} \text { water } / \mathrm{m}^{2}\end{array}$

Assuming the density of adsorbed water to be equal to that of bulk water, and taking the thickness of one molecular layer of water as 3 angstroms, the two porous rocks take on an amount of water equivalent to a uniform layer 13 molecules thick. : The corresponding figure for the granite is 33 molecules thick. Since the adsorbed layer is not likely to be more than about 10 molecules thick, it seems that some of the water is taken on by capillary condensation in the smallest pores, at least in the granite, which has a much smaller proportion of large pores than the other two rocks. : Data on pore size distribution measured by mercury intrusion are given below.

Table AI. Water adsorption in $\mathbf{1 0 0 \%}$ relative humidity environment.

\begin{tabular}{|c|c|c|c|c|c|c|}
\hline \multirow[b]{3}{*}{ Test } & \multicolumn{6}{|c|}{ Adsorbed water (g water/g rock) } \\
\hline & \multicolumn{2}{|c|}{ Berea sandstone } & \multicolumn{2}{|c|}{ Indiana limestone } & \multicolumn{2}{|c|}{ Barre granite } \\
\hline & Sample A & Sample B & Sample $A$ & Sample B & Sample $A$ & Sample B \\
\hline 1 & $5.1 \times 10^{-3}$ & $4.8 \times 10^{-3}$ & $2.2 \times 10^{-3}$ & $2.5 \times 10^{-3}$ & $1.2 \times 10^{-3}$ & $1.1 \times 10^{-3}$ \\
\hline 2 & $5.5 \times 10^{-3}$ & $5.5 \times 10^{-3}$ & $2.9 \times 10^{-3}$ & $3.0 \times 10^{-3}$ & $1.3 \times 10^{-3}$ & $1.1 \times 10^{-3}$ \\
\hline 3 & $6.6 \times 10^{-3}$ & $6.7 \times 10^{-3}$ & $4.2 \times 10^{-3}$ & $4.1 \times 10^{-3}$ & $1.4 \times 10^{-3}$ & $1.3 \times 10^{-3}$ \\
\hline 4 & $7.0 \times 10^{-3}$ & $7.1 \times 10^{-3}$ & $4.8 \times 10^{-3}$ & $4.4 \times 10^{-3}$ & $1.5 \times 10^{-3}$ & $1.5 \times 10^{-3}$ \\
\hline 5 & $7.3 \times 10^{-3}$ & $7.3 \times 10^{-3}$ & $4.5 \times 10^{-3}$ & $4.2 \times 10^{-3}$ & $1.4 \times 10^{-3}$ & $1.4 \times 10^{-3}$ \\
\hline 6 & $7.2 \times 10^{-3}$ & $6.8 \times 10^{-3}$ & $4.9 \times 10^{-3}$ & $5.3 \times 10^{-3}$ & $1.5 \times 10^{-3}$ & $1.3 \times 10^{-3}$ \\
\hline
\end{tabular}




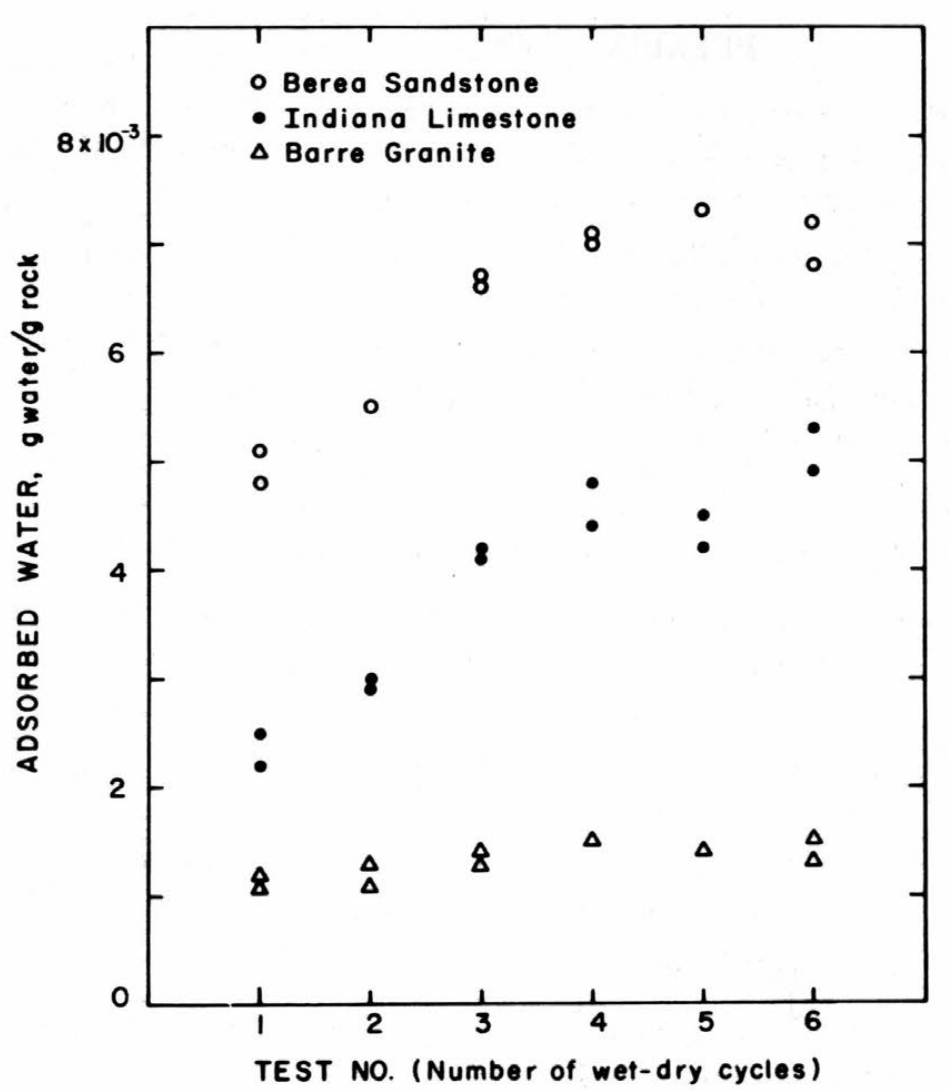

Figure A1. Water adsorption for successive exposures. 


\section{APPENDIX B: ADSORPTION AND ABSORPTION BY ROCHESTER SHALE}

In the two porous rocks, Berea sandstone and Indiana limestone, the adsorbed water is only a small fraction of the total amount of water which can be held by the rock (about $5 \%$ to $8 \%$ in both cases). : In the Barre granite, the adsorbed water is about $45 \%$ of the total water which can be adsorbed. :

Adsorption and absorption measurements were made on another type of rock, Rochester shale, which is the material underlying the caprock (Lockport dolomite) at Niagara Falls. : The test samples were cut from a fresh core drilled by the U.S. Army Corps of Engineers, Buffalo District, above the American Falls at Niagara. : The results were:

Adsorbed water: (A) $1.39 \times 10^{-2}$, (B) $1.41 \times 10^{-2} \mathrm{~g}$ water $/ \mathrm{g}$ rock

Absorbed (total) water: (A) $1.55 \times 10^{-2}$, (B) $1.58 \times 10^{-2} \mathrm{~g}$ water $/ \mathrm{g}$ rock.

In this rock, therefore, about $90 \%$ of the total water which can be held is adsorbed water. This adsorbed water is expected to be virtually unfreezable under the winter temperatures normally experienced at Niagara.

Dunn and Hudec found a strong correlation between the percentage of "unfreezable" water and the susceptibility of a rock to freeze/thaw deterioration. : According to such a criterion, Rochester shale would be a prime candidate for rapid deterioration under frost conditions. 


\section{APPENDIX C: LOW TEMPERATURE CONDUCTIVITY OF SATURATED WOOD}

During the tests on ice, one chamber of the cell was uncommitted, and it was used to make some measurements on saturated wood. The sole motivation was idle curiosity born of log-splitting at low temperatures.

The test sample was a cylindrical piece of hard maple, $1_{1 / 8}^{1 / 3}$ in. in diameter by $1 \frac{7}{8}$ in. long. : It was cut from a fresh length of dowel, and the ends were primed with silver paint. It was soaked in distilled water for 3 days before the test began.

The results are shown in Figure $\mathrm{C} 1$. One noteworthy feature of the curve is the peak which occurs at $-80^{\circ} \mathrm{C}$. There is also a "step" at about $-30^{\circ} \mathrm{C}\left(-40^{\circ}\right.$ is considered to be a good temperature for log splitting - temperatures above $-30^{\circ}$ are not as satisfactory).

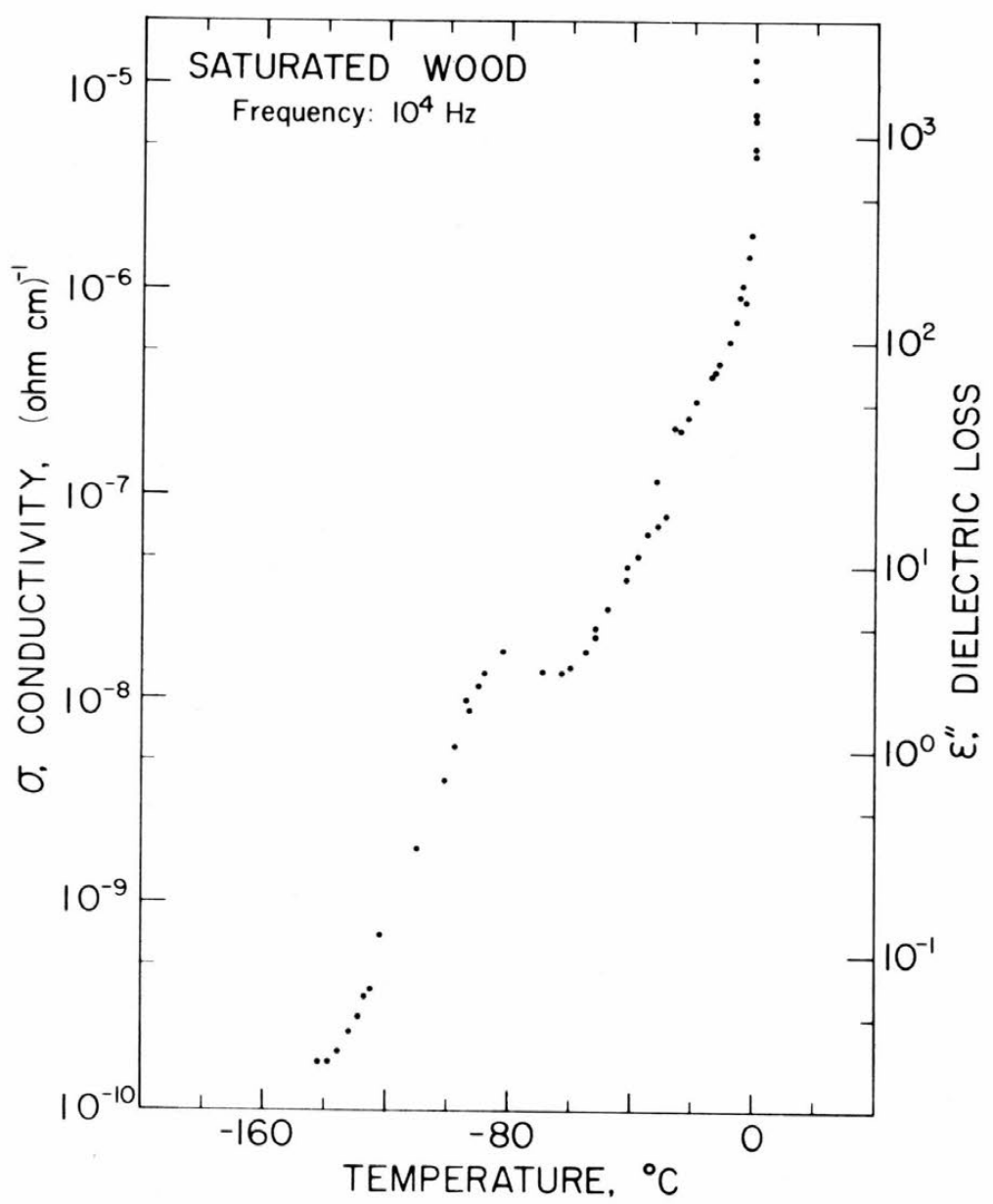

Figure C1. Conductivity at $10^{4} \mathrm{~Hz}$ as a function of temperature for saturated wood (hard maple). 


\section{DOCUMENT CONTROL DATA - R \& D}

(Security clessification of title, body of ebatract and indexing ennotation muat be entered when the overall report le cleaellled)

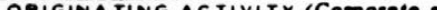

U.S. Army Cold Regions Research and

Engineering Laboratory

Hanover, New Hampshire 03755

3. MENONT TITLE

PHASE COMPOSITION OF PORE WATER IN COLD ROCKS

4. DESCAIPTIVE NOTES (TYPO of report and Inclueive dater)

B. AU THON(S) (Flret name, aniddle Inltial, laet name)

Malcolm Mellor

\begin{tabular}{|c|c|c|}
\hline G. REPOAT DATE December 1970 & $\begin{array}{l}\text { 7. TOTAL NO. OF PAGES } \\
62\end{array}$ & $\begin{array}{l}\text { 7b. NO. OF AEF S } \\
37\end{array}$ \\
\hline $\begin{array}{l}\text { D. CONTRACT OR GRANT NO. } \\
\text { D. PROJECT NO. }\end{array}$ & $\begin{array}{l}\text { 90. ORIGINATOA'B REPOAT } \\
\text { Research Re }\end{array}$ & 292 \\
\hline $\begin{array}{l}\text { e. DA Task 1T062112A13001 } \\
\text { d. }\end{array}$ & $\begin{array}{l}\text { Ob. OTHER REPORT NO(S) } \\
\text { this roport) }\end{array}$ & her numbore that may be acolchod \\
\hline
\end{tabular}

10. DISTAIQUTION STATEMENT

This document has been approved for public release and sale; its distribution is unlimited.

11. SUPRLEMENTARY NOTES

12. SPONSORING MILITARY ACTIVITY

U.S. Army Cold Regions Research and

Engineering Laboratory

Hanover, New Hampshire 03755

TI. ADSTACT

The phase composition of pore water in three types of rock subjected to temperature below $0^{\circ} \mathrm{C}$ was explored by a variety of techniques. Freezing point depression was measured as a function of water content by differential thermal analysis, the results yielding relationships between unfrozen water content and temperature. In an effort to avoid the practical difficulties involved in differential thermal analysis, attempts were made to determine freezing characteristics indire tly by air penetration and mercury penetration techniques applied at ordinary room temeratures. Electrical conductivity measurements were made as a function of temperature down to $-195^{\circ} \mathrm{C}$ in an attempt to obtain information on characteristics of interfacial water films at low temperatures. Thermal strain was measured as a function of temperature in order to detect direct mechanical effects associated with phase changes, chiefly strain discontinuities brought about by volume changes in the pore water during rapid freezing and thawing. Finally, isothermal compressibility measurements, with pressures up to $27 \mathrm{~kb}$, were made at $-10^{\circ} \mathrm{C}$ so as to determine whether the rock underwent step changes in volumetric strain at pressures corresponding to those of the phase boundaries for ice polymorphs.

14. Key Words Compressibility Electrical conductivity

Pore water, freezing

Rock mechanics

Phase transformations
Rock properties
Rock tests

Thermal expansion 